\title{
Prestressed Concrete Reactor Vessel Thermal Cylinder Model Study
}
J. P. Callahan
D. A. Canonico
M. Richardson
J. M. Corum
W. G. Dodge
G. C. Robinson
G. D. Whitman

\section{OAK RIDGE NATIONAL LABORATORY}

OPERATED BY UNION CARBIDE CORPORATION FOR THE ENERGY RESEARCH AND DEVELOPMENT ADMINISTRATION 


\section{DISCLAIMER}

This report was prepared as an account of work sponsored by an agency of the United States Government. Neither the United States Government nor any agency Thereof, nor any of their employees, makes any warranty, express or implied, or assumes any legal liability or responsibility for the accuracy, completeness, or usefulness of any information, apparatus, product, or process disclosed, or represents that its use would not infringe privately owned rights. Reference herein to any specific commercial product, process, or service by trade name, trademark, manufacturer, or otherwise does not necessarily constitute or imply its endorsement, recommendation, or favoring by the United States Government or any agency thereof. The views and opinions of authors expressed herein do not necessarily state or reflect those of the United States Government or any agency thereof. 


\section{DISCLAIMER}

Portions of this document may be illegible in electronic image products. Images are produced from the best available original document. 


\section{Printed in the United States of America. Available from National Technical Information Service \\ U.S. Department of Commerce 5285 Port Royal Road, Springfield, Virginia 22161 \\ Price: Printed Copy $\$ 5.50$; Microfiche $\$ 3.00$}

This report was prepared as an account of work sponsored by the United States Government. Neither the United States nor the Energy Research and Development Administration/United States Nuclear Regulatory Commission, nor any of their employees, nor any of their contractors, subcontractors, or their employees, makes any warranty, express or implied, or assumes any legal liability or responsibility for the accuracy, completeness or usefulness of any information, apparatus, product or process disclosed, or represents that its use would not infringe privately owned rights. 
ORNL/TM-5613

Dist. Category UC-77

Contract No. W-7405-eng-26

Engineering Technology Division

HTGR BASE TECHNOLOGY PROGRAM

Prestressed Concrete Nuclear Pressure

Vessel Development (189a. No. 01331)

PRESTRESSED CONCRETE REACTOR VESSEL THERMAL CYLINDER MODEL STUDY
J. P. Callahan
J. M. Corum
D. A. Canonico
W. G. Dodge
M. Richardson
G. C. Robinson

G. D. Whitman

Manuscript Completed - May 4, 1977

Date Published - June 1977

Prepared by the

OAK RIDGE NATIONAL LABORATORY

Oak Ridge, Tennessee 37830

operated by

UNION CARBIDE CORPORATION

for the

ENERGY RESEARCH AND DEVELOPMENT ADMINISTRATION

This tepost was prepared as an account of work This repor by the United States Govesnment. Neither the United States nor the United States Eny of Recearch and Development Admits thein contractors.

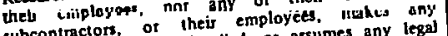
subcontractors, or theis implied, or assumes any legal warranty, express or inples, accuracy, completeness liebility or respons in informatian, apparatus, product on of usciulnes ned of tepresents process disclosed, ow ined rights.

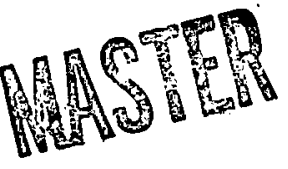


THIS PAGE

\section{WAS INTENTIONALLY \\ LEFT BLANK}


ACKNOWLEDGEMENTS $\ldots \ldots \ldots \ldots \ldots \ldots \ldots \ldots \ldots \ldots \ldots \ldots \ldots \ldots \ldots \ldots \ldots \ldots \ldots \ldots \ldots$

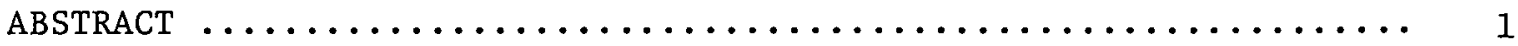

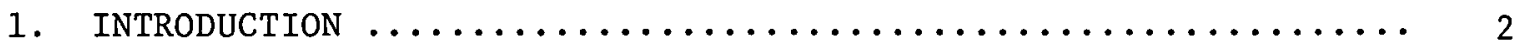

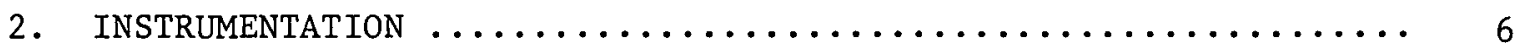

2.1 Stress and Strain Gages $\ldots \ldots \ldots \ldots \ldots \ldots \ldots \ldots \ldots \ldots \ldots \ldots$

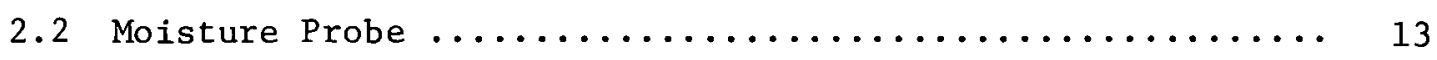

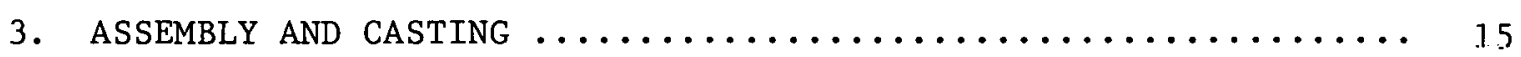

3.1 Assembly of Model $\ldots \ldots \ldots \ldots \ldots \ldots \ldots \ldots \ldots \ldots \ldots \ldots \ldots \ldots$

3.2 Temperature- and Pressure-Control Systems $\ldots \ldots \ldots \ldots \ldots \ldots$.

3.3 Casting of Model and Companion Specimens ............. 18

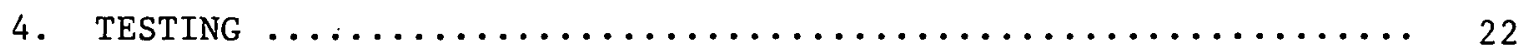

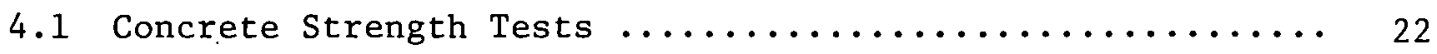

4.2 Posttensioning of Model $\ldots \ldots \ldots \ldots \ldots \ldots \ldots \ldots \ldots \ldots \ldots \ldots \ldots$

4.3 Simulated Vessel Operation $\ldots \ldots \ldots \ldots \ldots \ldots \ldots \ldots \ldots \ldots \ldots . \ldots \ldots$

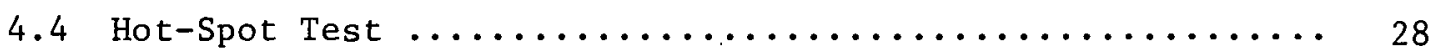

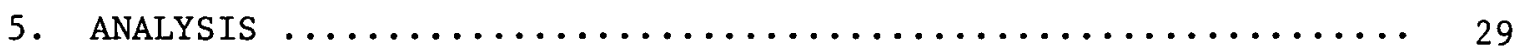

6. EXPERIMENTAL AND ANALYTICAL RESULTS $\ldots \ldots \ldots \ldots \ldots \ldots \ldots \ldots \ldots \ldots \ldots \ldots \ldots \ldots$

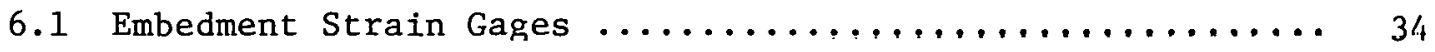

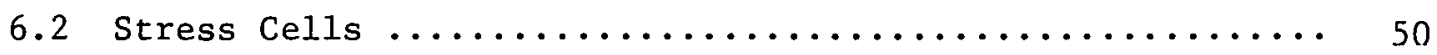

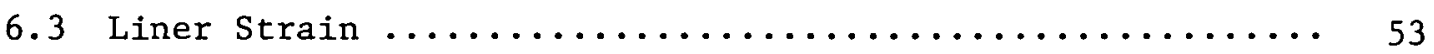

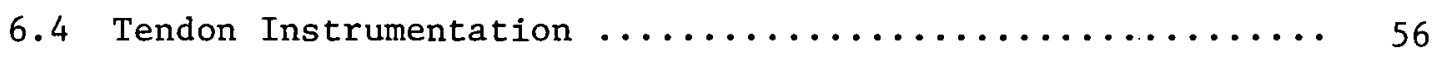

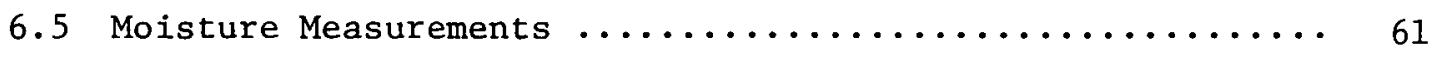

6.6 Companion Specimen Tests .................... 64

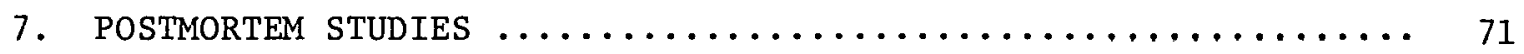

7.1 Disassembly of the Model $\ldots \ldots \ldots \ldots \ldots \ldots \ldots \ldots \ldots \ldots \ldots \ldots \ldots \ldots$

7.2 Rebound Hammer Test . . . . . . . . . . . . . . . 75

7.3 Prestressing Tendon Corrosion ................. 83

7.3.1 Description of axial tendons ............. 83

7.3.2 Metallurgical and chemical analyses ........... 87

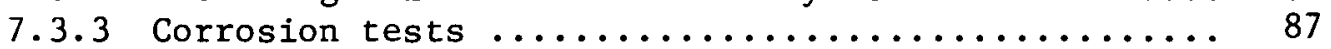

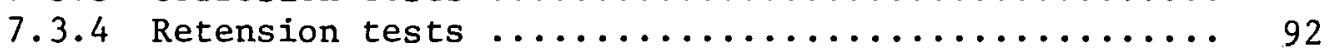

7.3 .5 Assessment of wire quality .............. 93

7.4 Correlation of Analytical Results with Model Test Data ... 96 
Page

8. CONCLUSIONS AND RECOMMENDATIONS $\ldots \ldots \ldots \ldots \ldots \ldots \ldots \ldots \ldots \ldots \ldots$

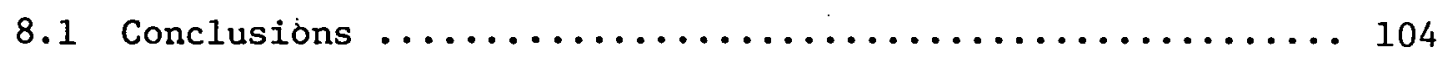

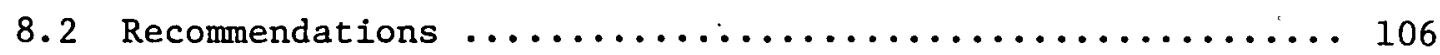

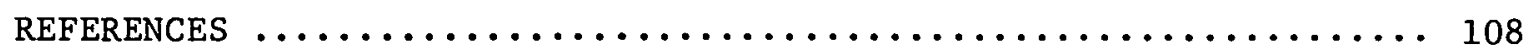




\section{ACKNOWLEDGMENTS}

The concept of the thermal cylinder model was originally discussed in a report entitled Design and Feasibility Study of a Large-Scale Test Simulating the Time-Dependent Behavior of a Prestressed Concrete Reactor Vessel, ORNL/TM-2390 (February 1969), by J. M. Corum and D. W. Goodpasture. The planning and execution of this complex experiment, which were accomplished essentially according to the original schedule, required the assistance and cooperation of numerous people in the Solid Mechanics Section, Engineering Technology Division, and in the Y-12 Plant. The authors are indebted to these people for their cooperation and concern for the success of the experiment. A note of appreciation is due R. S. Valachovic, S. E. Bolt, T. M. Cate, C. C. Hurtt, J. E. Smith, and D. N. Fanning, who made substantial contributions during various phases of the experiment. Spectal thanks is due H. D. Curtis for his work in the development of instrumentation, fabrication of the model, and monitoring of instrumentation.

The finite-element computer program used for the analysis was developed at the General Atomic Company by $Y$. R. Rashid. The analyses were conducted by J. S. Crowell and S. K. Iskander of the Computer Sciences Division. 


\title{
PRESTRESSED CONCRETE REACTOR VESSEL THERMAL CYLINDER MODEL STUDY
}
J. P. Callahan
J. M. Corum
D. A. Canonico
W. G. Dodge
M. Richardson
G. C. Robinson

G. D. Whitman

\begin{abstract}
The thermal cylinder experiment. was designed both to provide Information for evaluating the capability of analytical methods to predict the time-dependent stress-strain behavior of a 1/6-scale model of the barrel section of a single-cavity prestressed concrete reactor vessel and to demonstrate the structural behavior under design and off-design thermal conditions. The model was a thick-walled cylinder having a height of $1.22 \mathrm{~m}$, a thickness of $0.46 \mathrm{~m}$, and an outer diameter of 2.06 $\mathrm{m}$. It was prestressed both axially and circumferentially and subjected to $4.83 \mathrm{MPa}$ internal pressure together with a thermal crossfall imposed by heating the inner surface to $338.8 \mathrm{~K}$ and cooling the outer surface to $297.1 \mathrm{~K}$. Since the model was designed to study the behavior of the barrel section of a massive concrete structure, all exposed surfaces were sealed to prevent loss of moisture, and the ends of the cylinder were insulated to prevent heat flow in the axial direction.

The experiment utilized information developed from previous studies of concrete materials properties, trlaxial creep, instrumentation, analysis methods, and structural models. The initial 460 days of testing were divided into time periods that simulated prestressing, heatup, reactor operation, and shutdown. At the conclusion of the simulated operating period, the model was repressurized and subjected to localized heating at $505.4 \mathrm{~K}$ for 84 days to produce an off-design hot-spot condition.

Postmortem examinations revealed corrosion of axial prestressing tendons, with a number of tendons having failed. The corrosion was apparently caused by the development of an environment in the tendon ducts that was unique to this experiment.

Comparisons of experimental data with calculated values obtained using the SAFE-CRACK finite-element computer program showed that the program was capable of predicting time-dependent behavior in a vessel subjected to normal operating conditions, but that it was unable to accurately predict the behavior during off-design hot-spot heating. Readings made using a neutron and gamma-ray backscattering moisture probe showed little, if any, migration of moisture in the concrete cross section. Destructive examination indicated that the model maintained its basic structural integrity during localized hot-spot heating.
\end{abstract}




\section{INTRODUCTION}

Prestressed concrete reactor vessels (PCRVs) are unique with respect to concrete technology primarily because of the elevated operating temperatures employed. In the ORNL Prestressed Concrete Reactor Vessel Research and Development Program, ${ }^{3}$ analytical methods have been developed and basic test data obtained for time-dependent deformation behavior of concrete. By incorporating these data into an appropriate analysis, predictions of time-dependent behavior of PCRVs can be made. Thus far, however, there have been limited means for assessing the accuracy of such analytical predictions. The thermal cylinder test is designed to provide the kind of information needed to make such an assessment.

The thermal cylinder is an approximately 1/6-scale model of the middle, or barrel, section of the cylindrical portion of a prestressed concrete reactor vessel, as shown in Fig. 1.1, which was subjected to the simulated in-service operating conditions shown diagrammatically in Fig. 1.2. The

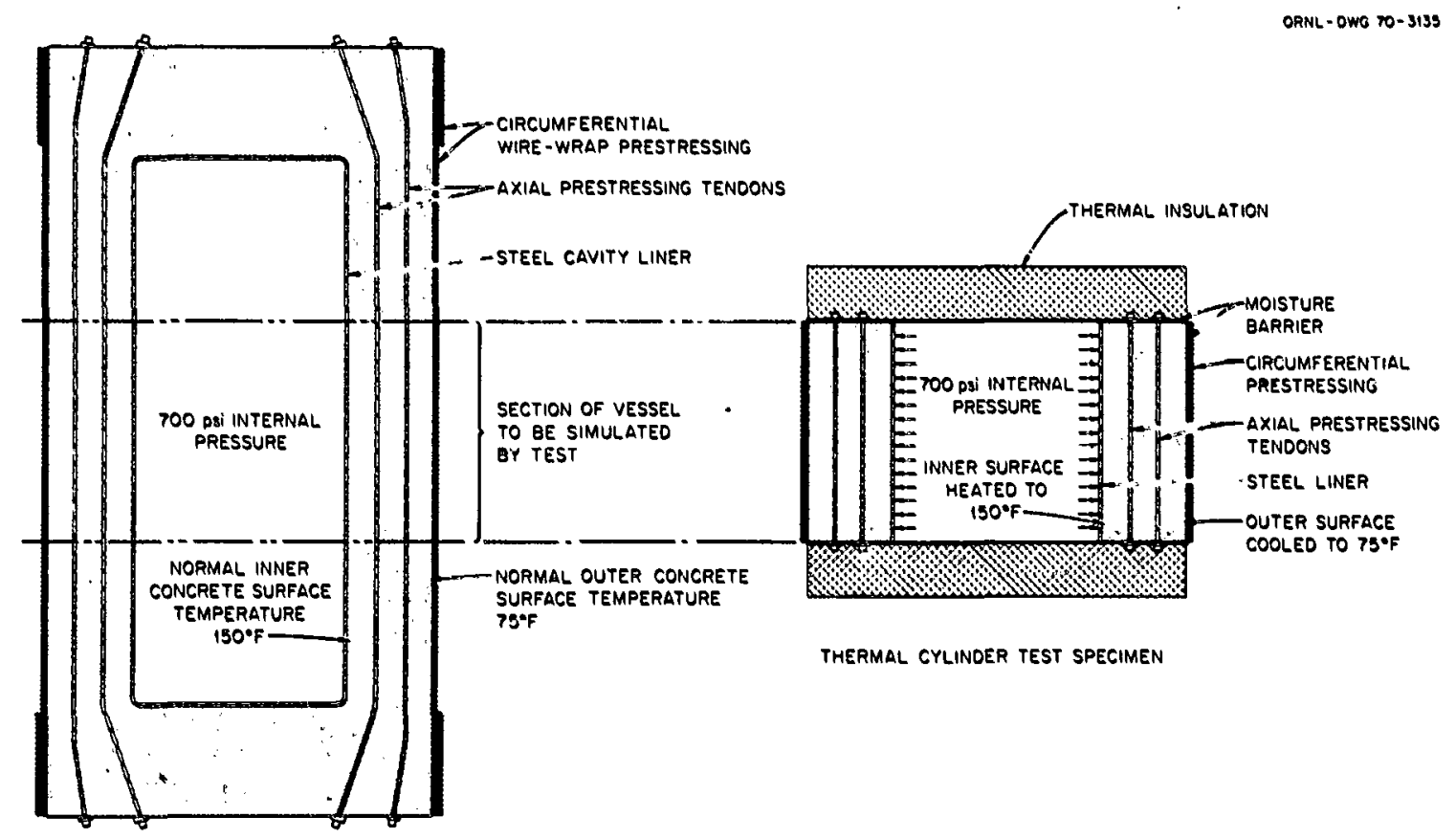

PRESTRESSED CONCRE TE REACTOR VESSEL

Fig. 1.1. Relationship of thermal cylinder test model to prestressed concrete reactor vessel $\left[1 \mathrm{psi}=6895 \mathrm{~Pa} ; \mathrm{K}=273.15+5 / 9\left({ }^{\circ} \mathrm{F}-32\right)\right]$. 

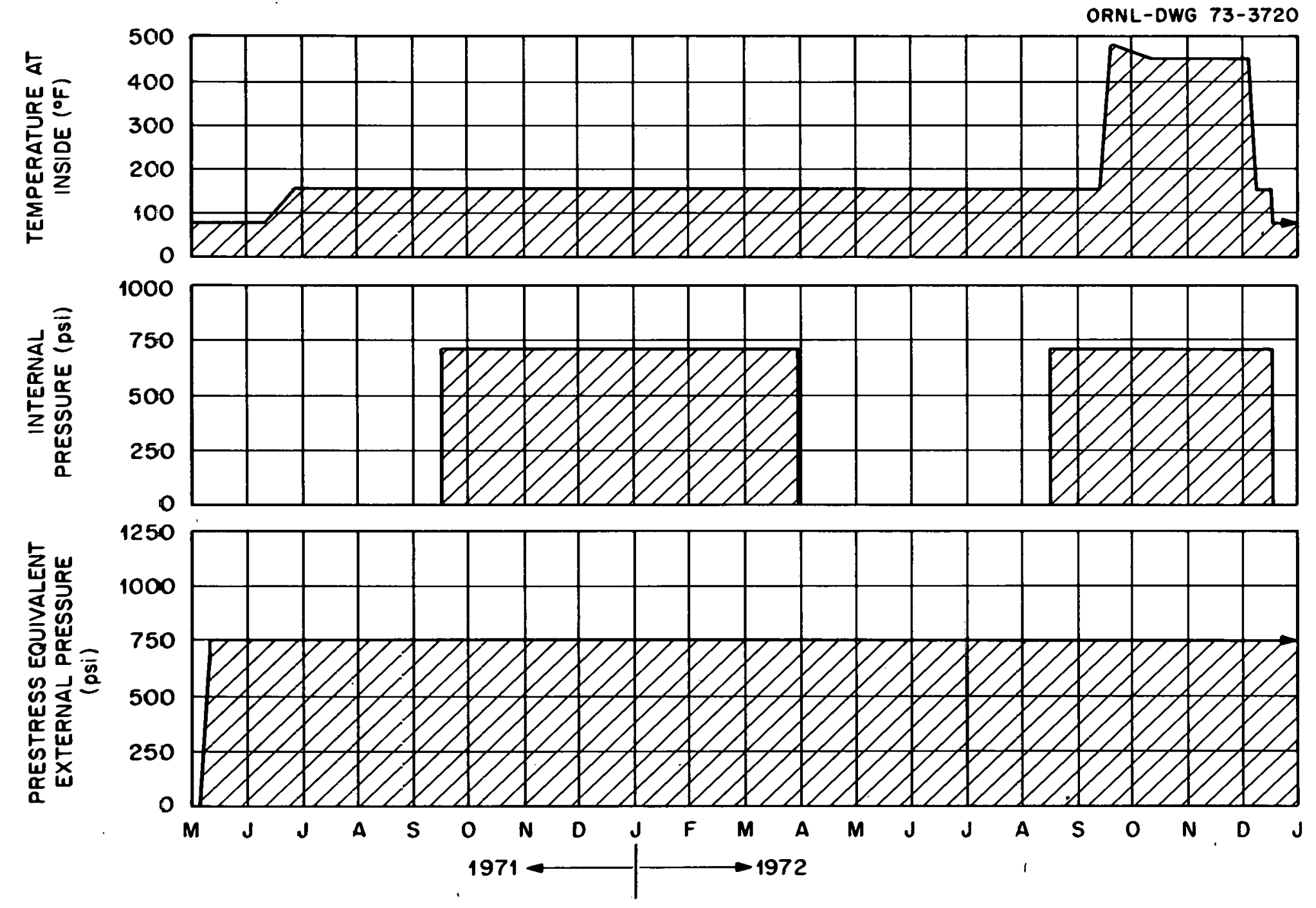

Fig. 1.2. Temperature and loading history of the thermal cylinder $\left[1\right.$ psi $\left.=6895 \mathrm{~Pa} ; \mathrm{K}=273.15+5 / 9\left({ }^{\circ} \mathrm{F}-32\right)\right]$. 
test structure, described in detail in Refs. 2 and 3, is a thick-walled cylinder having a height of $1.22 \mathrm{~m}$, a thickness of $0.46 \mathrm{~m}$, and an outer diameter of $2.06 \mathrm{~m}$.

The prestressing arrangement is shown in Fig. 1.3. There were 52 axial tendons arranged in two rows of 26 tendons each. The S.E.E.E. anchor system was used with the axial tendons. A unique arrangement was employed for the circumferential prestressing; monostrand tendons were wrapped around the outer surface of the cylinder and posttensioned by jacking them outwardly, as shown in Fig. 1.3. The axial and circumferential tendons

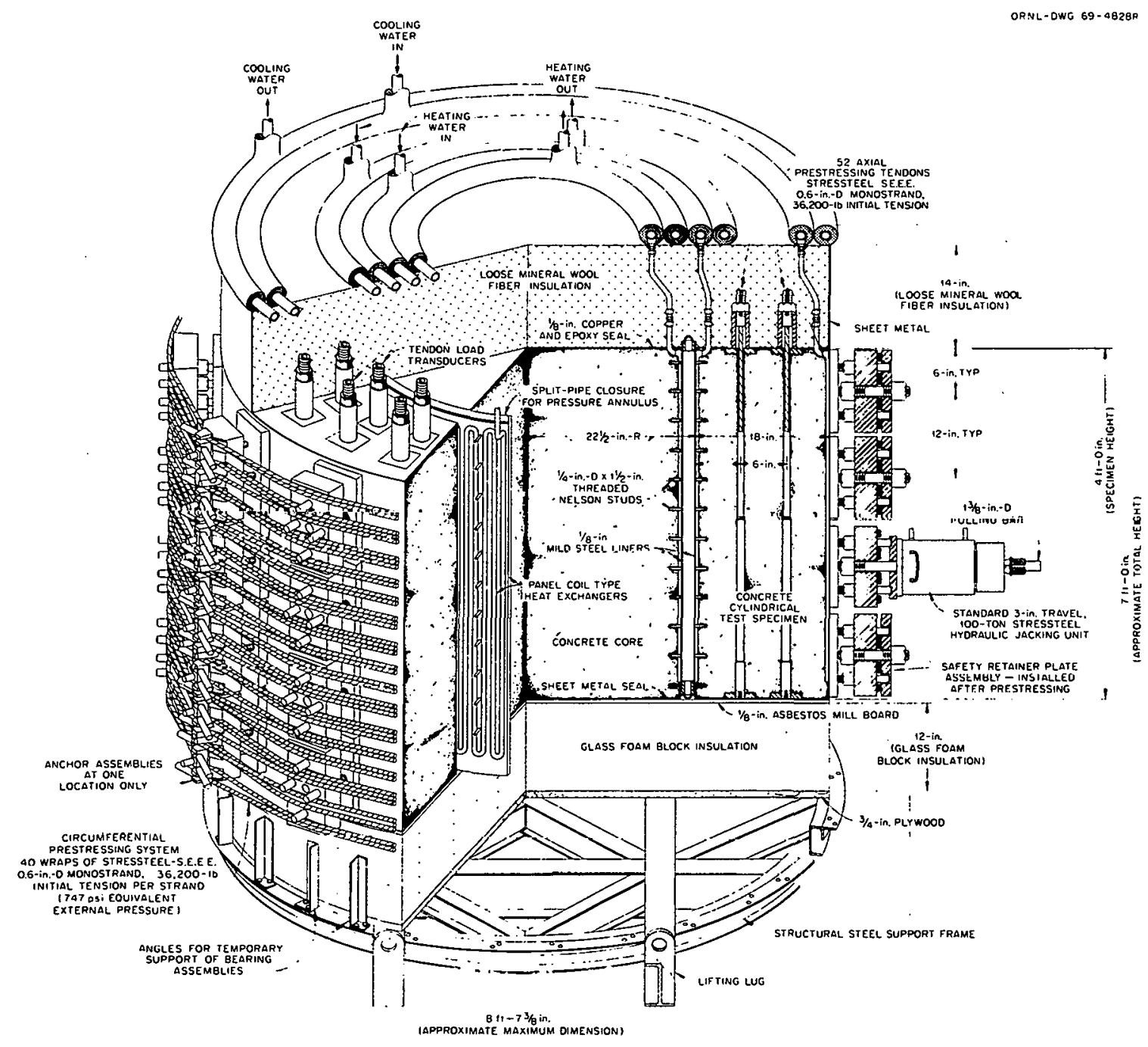

Fig. 1.3. Isometric drawing of the thermal cylinder test structure $(1$ in. $=25.4 \mathrm{~mm} ; 1 \mathrm{ft}=0.305 \mathrm{~m})$. Initial tension per strand is $0.161 \mathrm{MN}$ $(36,200 \mathrm{lb})$, equivalent to 5.15-MPa (747-psi) external pressure. 
consisted of seven-wire strands manufactured in accordance with ASTM A416. LCK-STRESS strand was specified to reduce relaxation losses. The strand had a nominal diameter of $1.54 \mathrm{~cm}$, a breaking strength of $24,500 \mathrm{~kg}$, and a nominal steel area of $1.39 \mathrm{~cm}^{2}$. The approximate modulus of elasticity was $193 \mathrm{GPa}$.

All surfaces of the model were sealed to prevent any moisture loss, and the ends were insulated thermally to limit heat flow to the radial direction. The model was prestressed (in practice, it was actually posttensioned) axially and circumferentially, and a 4.83-MPa internal pressure was applied through a pressurizing annulus, as shown in Fig. 1.3. The inner cavity of the cylinder contained a concrete core, which provided the inner support for the relatively thin pressurizing annulus. Since pressurization of the annulus induced a purely biaxial stress state in the core, the behavior of this region, as well as the outer test ring, provided basic information on the behavior of both the concrete and the instrumentation. The model was highly instrumented, and, in addition to providing experimental data on structural behavior, it also provided an opportunity to evalute instrument performance under conditions simulating PCRV design and off-design conditions.

A thermal. gradient was imposed by heating the inner surface of the cylinder to $338.7 \mathrm{~K}$ and cooling the outer surface to $279.0 \mathrm{~K}$ to represent normal PCRV operation. During a subsequent period, a narrow circumferential band on the inner surface of the test section was heated to $505.4 \mathrm{~K}$ and maintained at that temperature for a period of 84 days. This second phase of the test simulated an off-design hot-spot condition in which the cooling and/or the insulation is assumed to have failed in an operating nuclear reactor.

The overall study was divided into the following phases:

1. instrumentation callbration,

2. assembly and casting of model and companion specimens,

3. model testing,

4. analytical studies,

5. comparison of experimental and analytical results,

6. postmortem studies

Each phase is discussed in the following sections. 


\section{INSTRUMENTATION}

\subsection{Stress and Strain. Gages}

Complete data sets were recorded during each experimental event, using the 155 gages listed in Table 2.1. The instrumentation consisted of embedment gages cast directly into the concrete and more conventional types of resistance strain gages attached to the liner and prestressing tendons. The radial positions of the various embedment gages are shown in Fig. 2.1. Generally, the initial letter of the gage designations used in the figure and listed in Table 2.1 indicates the quadrant of the model in which the gage is located (A, B, C, or D), and this is followed by one or two letters or a letter and a number designating the gage type. The first number of the three-number series that follows the letters indicates relative radial position from the inside of the test section; the last number indicates the orientation ( $1 . e ., 1=\operatorname{axial}, 2$ = radial, and 3 = circumferential); and the middle number is used to further identify individual sensors. Information on the operability of the gages before the hot-spot test and at the end of the experiment is also provided in Table 2.1.

A total of 12 of the 52 axial prestressing tendons were instrumented with bonded electrical resistance strain gages and load-calibrated in a tensile testing machine. In addition, 12 load cells that were designed and fabricated for use with the instrumented axial tendons were loadcalibrated in compression. The locations of the instrumented tendons on the model are shown in Fig. 2.2 relative to $A, B, C$, and $D$ quadrants. This combination of instrumented tendons and load transducers was used to determine the relationship between the initial stress developed during posttensioning of the tendons and the actual load transferred to the structure. In addition, it provided a means for monitoring possible creep and stress relaxation of the tendons. Strains in the circumferential tendons were monitored using strain gages that were bonded to 8 of the 16 circumferential tendons shown in F1g. 2.2. In the case of the circumferential tendons, no practical way was found to include load cells. 
Table 2.1. Thermal cylinder instrumentation

\begin{tabular}{|c|c|c|c|c|c|c|}
\hline Type of gage & & $\begin{array}{l}\text { Cylinder } \\
\text { quadrant }\end{array}$ & $\begin{array}{l}\text { Gage } \\
\text { No. }\end{array}$ & Orientation & $\begin{array}{l}\text { Status before } \\
\text { hot-spot test }\end{array}$ & $\begin{array}{l}\text { Final } \\
\text { status }\end{array}$ \\
\hline \multicolumn{7}{|c|}{ Embedment strain gages } \\
\hline \multirow[t]{47}{*}{ Single-filament resistance } & A & & $E B-131$ & Axial & Operative & Operative \\
\hline & A & & $E B-231$ & Axial & Operative & Operative \\
\hline & A & & $E B-351$ & Axial & Operative & Operative \\
\hline & A & & EB-132 & Radial & Inoperative & Inoperative \\
\hline & A & & $E B-232$ & Radial & Operative & Operative \\
\hline & A & & $E B-352$ & Rad lal & Operal ive & Operative \\
\hline & A & & EB-133 & Circumferential & Inoperative & Inoperative \\
\hline & A & & $\mathrm{EB}-233$ & Circumferential & Operative & Operative \\
\hline & A & & EB-353 & Circumferential & Operative & Inoperative \\
\hline & B & & $E B-151$ & Axial & Operative & Operative \\
\hline & B & & $E B-251$ & Axial & Operative & Operative \\
\hline & B & & $E B-351$ & Axial & Operative & Operative \\
\hline & B & & $E B-152$ & Radial & Operative & Operative \\
\hline & B & & $E B-252$ & Radial & Operative & Operative \\
\hline & B & & $E B-153$ & Circumferential & Operative & Inoperative \\
\hline & B & & $E B-253$ & Circumferential & Operative & Operative \\
\hline & B & & $E B-353$ & Circumferential & Operative & Operative \\
\hline & C & & $E B-151$ & Axial & Operative & Operative \\
\hline & C & & $E B-241$ & Axial & Operative & Operative \\
\hline & C & & $E B-341$ & Axial & Operative & Operative \\
\hline & C & $\cdot$ & $E B-152$ & Radial. & Operative & Inoperative \\
\hline & C & & $E B-242$ & Radial & Inoperative & Inoperative \\
\hline & $\mathrm{C}$ & & $E B-342$ & Radial & Operative & Operative \\
\hline & C & & $E B-153$ & Circumferential & Operative & Inoperative \\
\hline & $\mathrm{C}$ & & $E B-243$ & Circumferential & Operative & Operative \\
\hline & $\mathrm{C}$ & & $E B-343$ & Circumferential & Operative & Operative \\
\hline & $\mathrm{C}$ & (core). & $E B-141$ & Axial & Operative & Inoperative \\
\hline & $\mathrm{C}$ & (core) & $E B-251$ & Axial & Operative & Inoperative \\
\hline & C & (core) & $E D-341$ & Axial & Operative & Inoporativo \\
\hline & $\mathrm{C}$ & (core) & $E B-342$ & Radial & Operative & Inoperative \\
\hline & C & (core) & $E B-143$ & Circumferential & Operative & Inoperative \\
\hline & C & (core) & $E B-253$ & Circumferential & Operative & Inoperative \\
\hline & D & & $E B-151$ & Axial & Operative & Operative \\
\hline & $D$ & & $E B-251$ & Axial & Operative & Operative \\
\hline & D & & $E B-341$ & Axial & Operative & Operative \\
\hline & D & & $E B-152$ & Radial & Operacive & Operative \\
\hline & D & & $E B-252$ & Radial & Inoperative & Inoperative \\
\hline & $\mathrm{D}$ & & $\mathrm{ER}-342$ & Radial & Operative & Operative \\
\hline & D & & $E B-153$ & Circumferential & Operative & Inoperative \\
\hline & D & & $E B-253$ & Circumferential & Operative & Operative \\
\hline & D & & $E B-343$ & Circumferential & Operative & Operative \\
\hline & D & (hot spot) & HS-1-13-1 & Axial & Inoperative & Inoperative \\
\hline & D & (hot spot) & HS- $2-10-1$ & Axial & Inoperative & Inoperative \\
\hline & $\mathbf{b}$ & (hot spoc) & HS $-1-12-2$ & Radial & Opetátive & Operative \\
\hline & D & (hot spot) & HS-2-11-2 & Radial & Inoperative & Inoperative \\
\hline & $\mathrm{D}$ & (hot spot) & HS $-1-15-3$ & Circumferential & Operative & Operative \\
\hline & D & (hot spot) & HS-2-11-3 & Circumferential & Inoperative & Inoperative \\
\hline \multirow[t]{8}{*}{ Vibrating wire (type A) } & B & & $06-101$ & Axial & Inoperative & Inoperal ive \\
\hline & B & & D6-102 & Radial & Inoperative & Inoperative \\
\hline & B & & D9-103 & Circumferential & Inoperative & Inoperative \\
\hline & C & & D9-101 & Axial & Inoperative & Inoperative \\
\hline & C & & D9-201 & Axial & Operative & Operative \\
\hline & $\mathrm{C}$ & & D9-301 & Axial & Inoperative & Inoperative \\
\hline & $\mathrm{C}$ & & D9-401 & Axial & Inoperative" & Inoperative \\
\hline & $\mathrm{C}$ & & D9- 102 & Radial & Inoperative & Inoperative \\
\hline
\end{tabular}


Table 2.1 (continued)

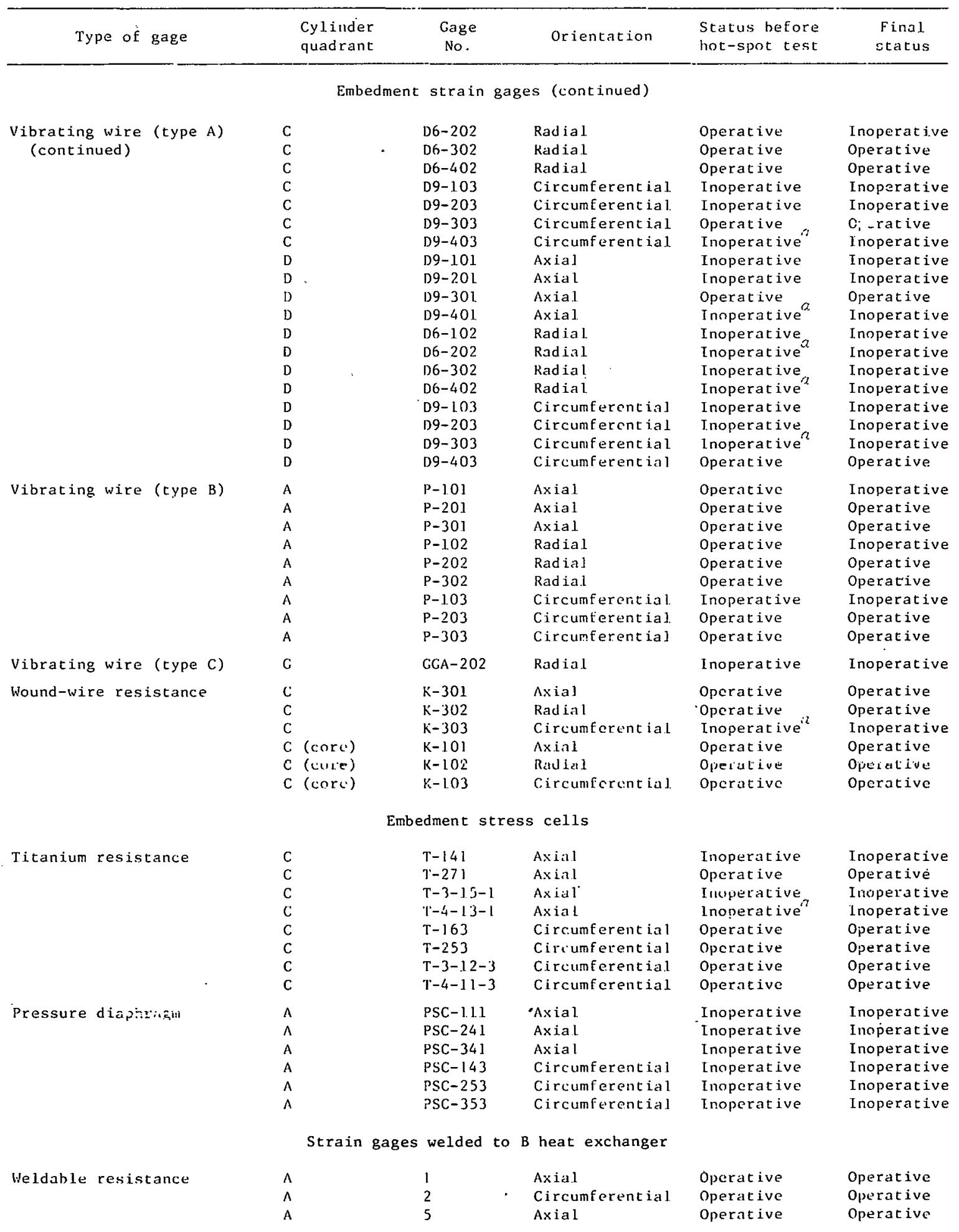


Table 2.1 (continued)

\begin{tabular}{|c|c|c|c|c|c|}
\hline Type of gage & $\begin{array}{l}\text { Cylinder } \\
\text { quadrant }\end{array}$ & $\begin{array}{l}\text { Gage } \\
\text { No. }\end{array}$ & Orientation & $\begin{array}{l}\text { Status before } \\
\text { hot-spot test }\end{array}$ & $\begin{array}{l}\text { Final } \\
\text { status }\end{array}$ \\
\hline
\end{tabular}

Strain gages welded to $B$ heat exchanger (continued)

Weldable resistance (continued)
Bunded foll

Stréss transducer

A
B
B
B
B
C
C
C
C
D
D
D
D
D (hot spot)
D (hot spot)
D (hot spot)

6
1
2
5
6
1
2
5
6
1
2
5
6
HS - 1
HS- 2
HS-

$\begin{array}{ll}\text { Circumferential } & \text { Inoperative } \\ \text { Axial } & \text { Inoperative } \\ \text { Circumferential } & \text { Inoperative } \\ \text { Axial } & \text { Operative } \\ \text { Circumferential } & \text { Inoperative } \\ \text { Axial } & \text { Inoperative } \\ \text { Circumferential } & \text { Inoperative } \\ \text { Axial } & \text { Operative } \\ \text { Circumferential } & \text { Operative } \\ \text { Axial } & \text { Operative } \\ \text { Circumferential } & \text { Operative } \\ \text { Axial } & \text { Operative } \\ \text { Circumferential } & \text { Operative } \\ \text { Axial } & \text { Inoperative } \\ \text { Circumferential } & \text { Inoperative } \\ \text { Axial } & \text { Operative }\end{array}$

Inoperative Inoperative Operative Operative Inoperative Inoperative Operative Operative Operative Operative Operative Operative Operative Inoperative

Inoperative

Strain gages bonded to axial prestressing tendons

$\begin{array}{lll}\text { A } & \text { CB-11A } & \text { Axial } \\ \text { A } & \text { CB-12A } & \text { Axial } \\ \text { B } & \text { CB-5A } & \text { Axial } \\ \text { B } & \text { CB-6A } & \text { Axial } \\ \text { C } & \text { CB-1A } & \text { Axial } \\ \text { C } & \text { CB-2A } & \text { Axial } \\ \text { C } & \text { CB-3A } & \text { Axial } \\ \text { C } & \text { CB-4A } & \text { Axial } \\ \text { D } & \text { CB-7A } & \text { Axial } \\ \text { D } & \text { CB-8A } & \text { Axial } \\ \text { D } & C B-9 A & \text { Axial } \\ \text { D } & C B-10 A & \text { Axial }\end{array}$

Inoperative Inoperative Inoperative Inoperative Inoperative Operative Inoperative Operative Inoperative Operative Inoperative Operative

Operative Operative Inoperative Operative Operative Operative Inoperative Operative Inoperative Operative Operative Operative

Load cells on axial prestressing tendons

$\begin{array}{lllll}\text { A } & \text { TR-11 } & \text { Axial } & \text { Inoperative } & \text { Operative } \\ \text { A } & \text { TR-12 } & \text { Axial } & \text { Operative } & \text { Operative } \\ \text { B } & \text { TR-5 } & \text { Axial } & \text { Inoperative } & \text { Operative } \\ \text { B } & \text { TR-6 } & \text { Axial } & \text { Operative } & \text { Operative } \\ \text { C } & \text { TR-1 } & \text { Axial } & \text { Inoperative } & \text { Inoperative } \\ \text { C } & \text { TR-2 } & \text { Axial } & \text { Operative } & \text { Operative } \\ \text { C } & \text { TR-3 } & \text { Axial } & \text { Inoperative } & \text { Operative } \\ \text { C } & \text { TR-4 } & \text { Axial } & \text { Operative } & \text { Operative } \\ \text { D } & \text { TR-7 } & \text { Axial } & \text { Operative } & \text { Operative } \\ \text { D } & \text { TR-8 } & \text { Axial } & \text { Operative } & \text { Operative } \\ \text { D } & \text { TR-9 } & \text { Axial } & \text { Operative } & \text { Operative } \\ \text { D } & \text { TR- } 0 & \text { Axial } & \text { Operative } & \text { Operative }\end{array}$

Strain gages bonded to circumferential prestressing tendons

Bonded foil

$\begin{array}{ll}\text { B } & C G A-1 \\ B & C G A-2 \\ B & C G B-1 \\ B & C G B-2 \\ B & C G C-1 \\ B & C G C-2 \\ B & C G D-1 \\ B & C G D-2\end{array}$

Circumferential Circumferential Circumferential Circumferential Circumferential Circumferential Circumferential Circumferential

Operative Operative Operative Operative Operative Operative Operative Operiative

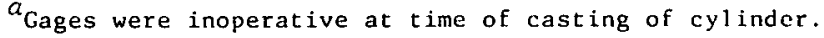



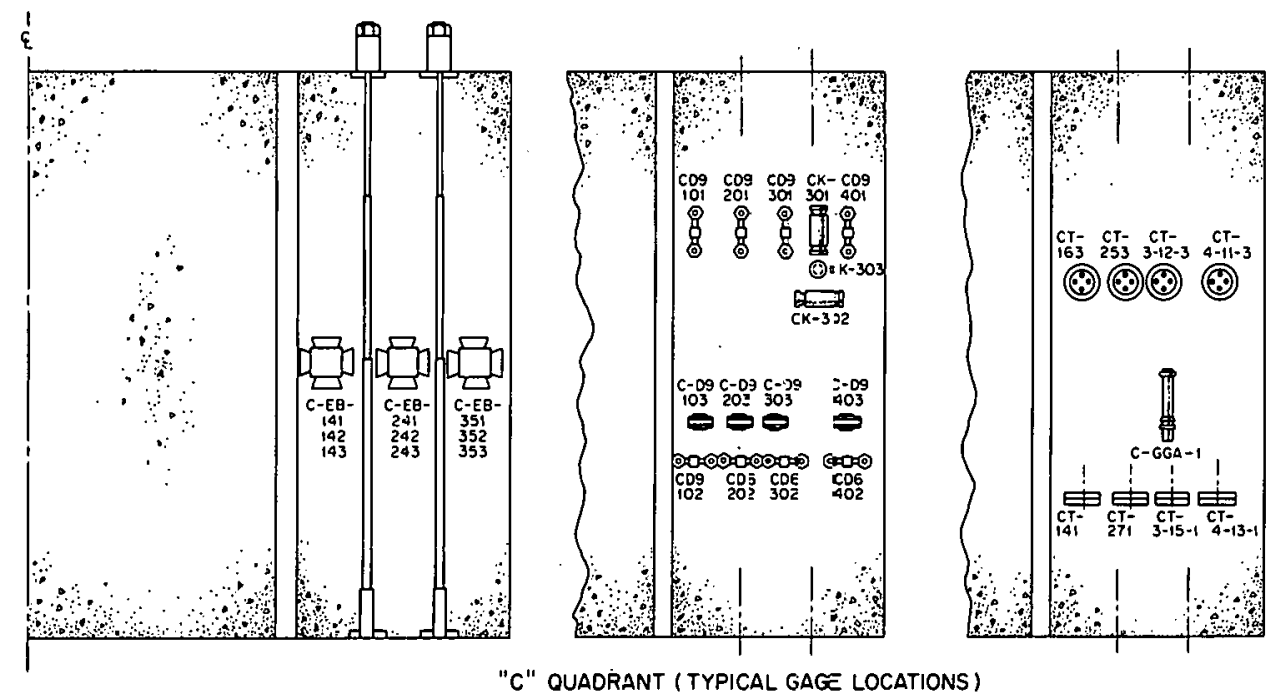

"C" QUAORANT (TYPICAL GAGE LOCATIONS)
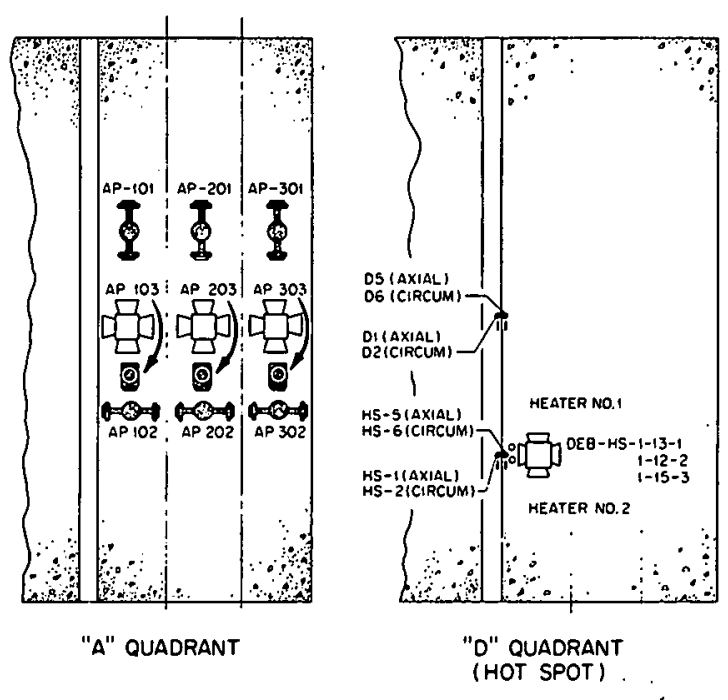

Fig: 2.1. Typical lccations of each type of embedment gage. 
ORNL-DWG $73-3721 R$

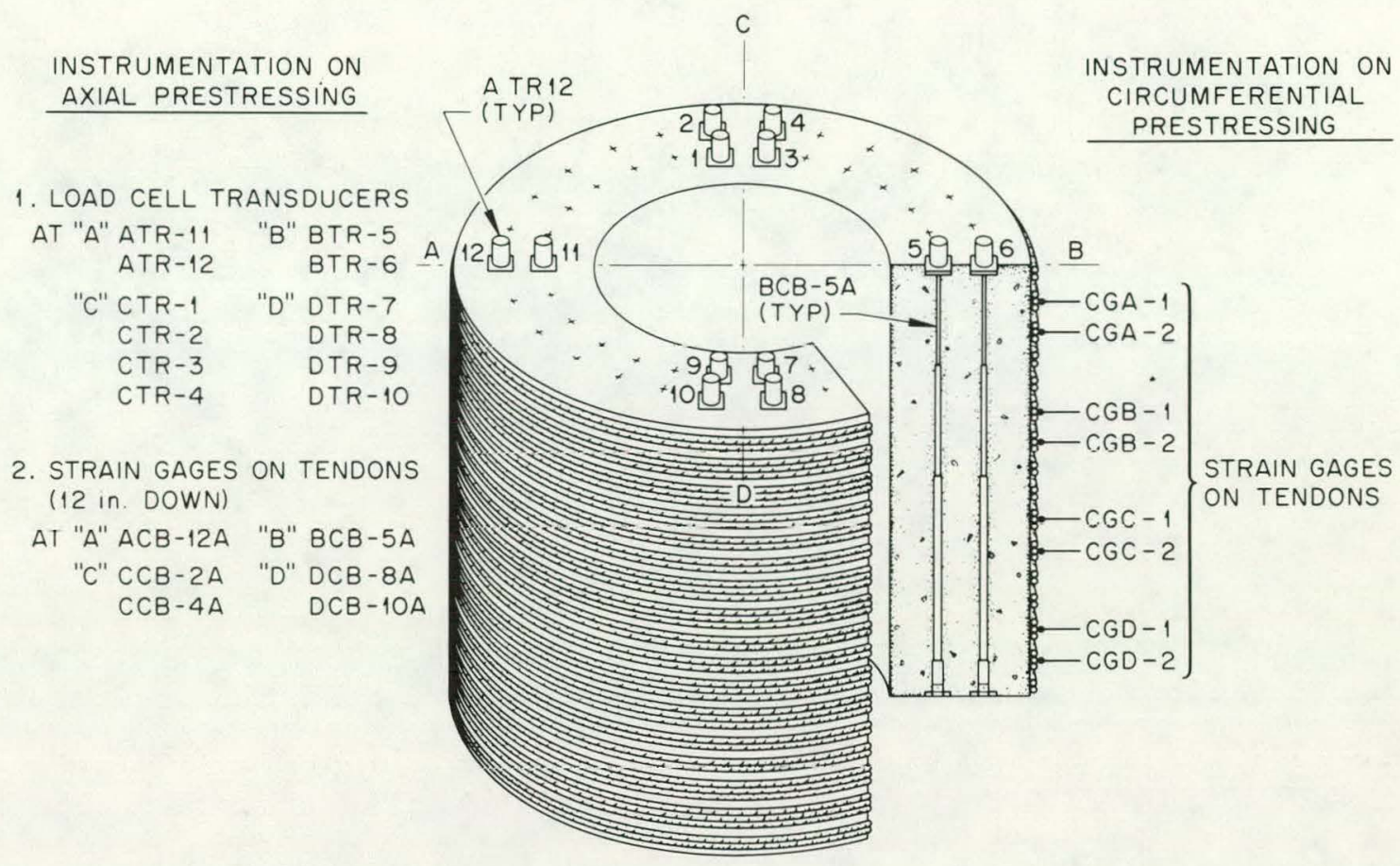

Fig. 2.2. Instrumentation on axial and circumferential prestressing (1 in. $=25.4 \mathrm{~mm})$.

Relaxation of the stress in concrete is an important consideration in the design of a PCRV. Two types of embedment devices having a potential for measuring stress relaxation were developed at ORNL for this experiment. One device, consisting of two parallel concrete embedment strain gages, one of which has a pressure diaphragm attached, was described in Ref. 3 and is discussed further in Section 6.2. The relatively thin cylindrical cell shown in Fig. 2.3 is another device designed for measuring stress in concrete. The cell, which consists of two machined titanium disks, is shown disassembled in Fig. 2.4. The disks fit together in such a way as to continually deflect a cruciform-shaped spring steel beam instrumented with a four-arm bonded strain gage bridge. The application of an axial compressive stress to the assembled cell will further deflect the cruciform beam as monitored by the strain gages.

In order to provide a means for measuring possible variations in strain readings unrelated to existing stress conditions, the titanium disk through which the strain gage leads pass (see Fig. 2.4) houses a 


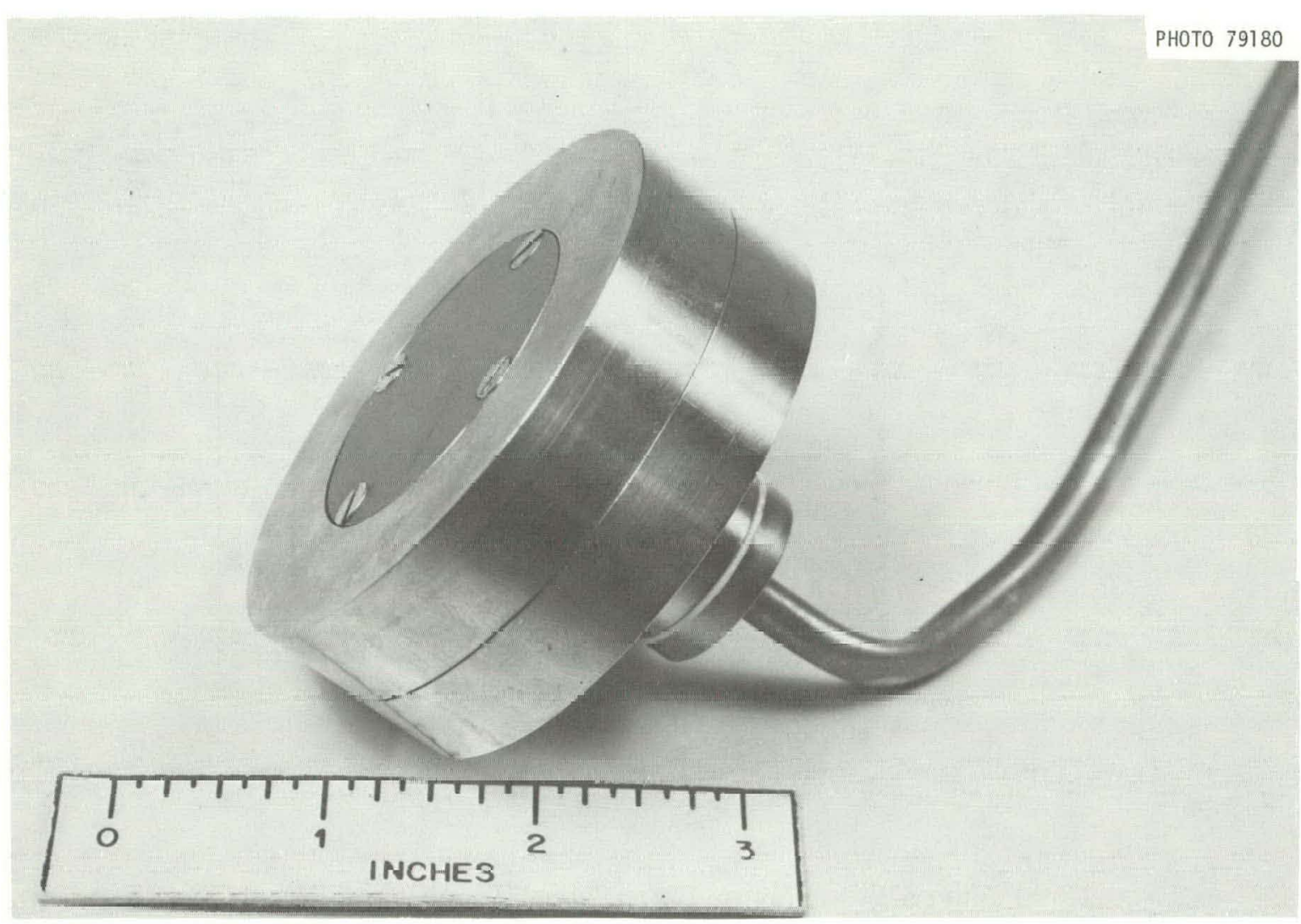

Fig. 2.3. Assembled titanium stress cell ( 1 in. $=25.4 \mathrm{~mm}$ ).

miniaturized pneumatic ram. When activated, the ram deflects the cruciform beam to a fixed reference stop that is designed to remain independent of stress variations. Changes in successive readings of the beam gage in the fixed deflection position can be used to determine the amount of instrumentation drift. Upon release of the pressure, the beam returns to its former position.

The stress cell was fabricated of titanium in order to produce an embedment having a coefficient of thermal expansion compatible with that of the concrete. Thirteen titanium stress cells were load-calibrated under uniaxial compression; nine of these were installed in the thermal cylinder, and the reniainder were installed in two 45.7- by $101.6-\mathrm{cm}$ concrete cylinders used to provide calibration of the embedded instrumentation.

A representative number of the single-filament resistance concrete embedment strain gages were calibrated in an oil bath using specialized equipment developed at the University of California as part of the ORNL 


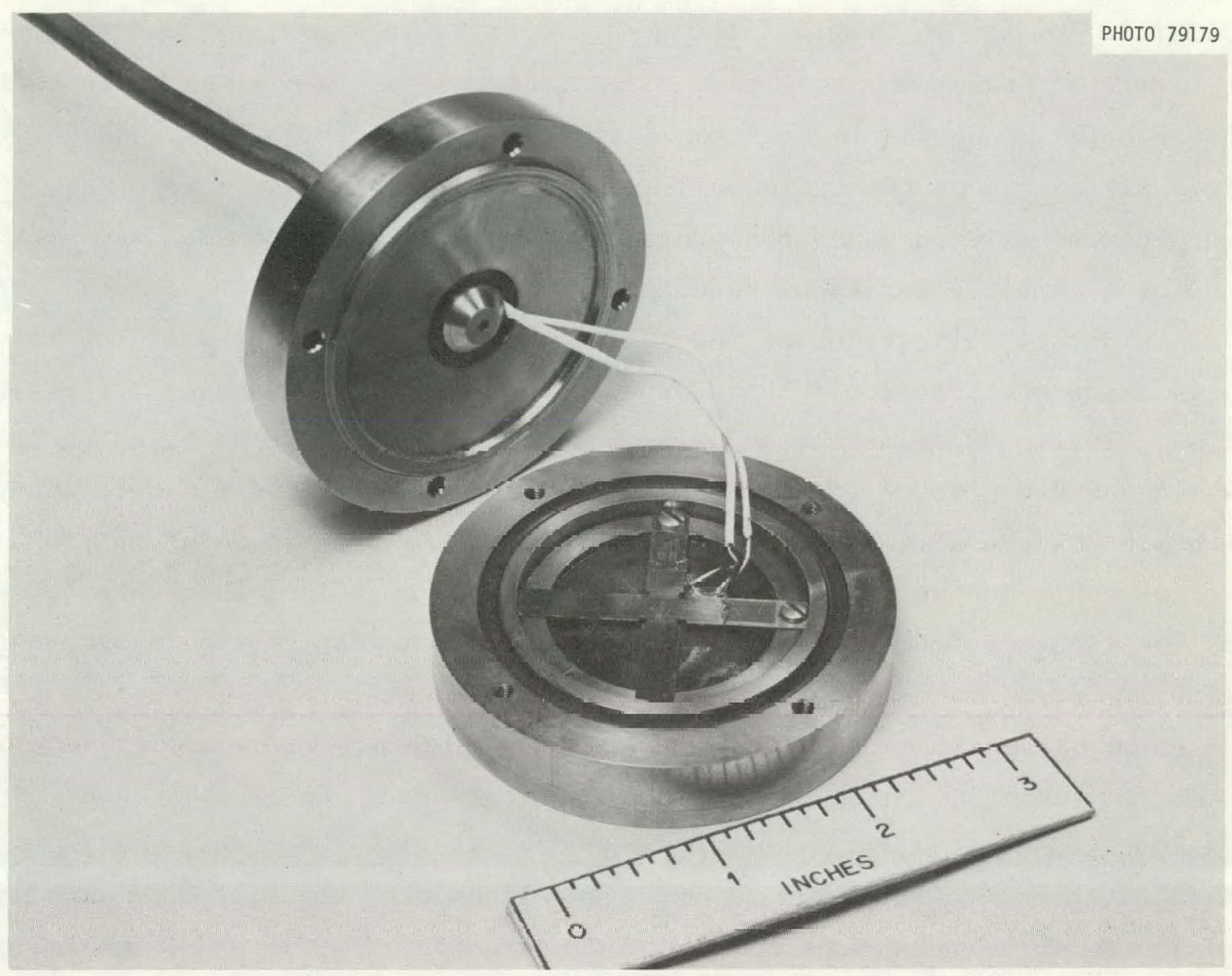

Fig. 2.4. Disassembled titanium stress cell (1 in. $=25.4 \mathrm{~mm}$ ).

concrete program. ${ }^{4}$ Gage calibration factors provided by the gage manufacturers were used for the remainder of the instrumentation.

The vibrating-wire gages and wire-wound resistance gages were monitored using seperate readout equipment. The remainder of the instrumentation, which also included 25 related thermocouples, was monitored with a computer-controlled data-acquisition system.

\subsection{Moisture Probe}

In order to provide information regarding the adequacy of the moisture seal and possible migration of moisture within the thermal cylinder, moisture readings were made, using a probe-type neutron and gamma-ray backscattering instrument, Readings were taken periodically, beginning just 
prior to heatup, by lowering the moisture probe into sixteen 25.4-mm-OD thin-walled stainless steel tubes cast into the specimen along three radial lines. The probe was lowered to vertical positions $15.2,45.7$, and $76.2 \mathrm{~cm}$ from the bottom of the cylinder. Sets of three 1-min counts were made at each position, with standard counts being made at the beginning and at the end of a complete series of readings.

A direct calibration of the moisture probe was conducted at the Waterways Experiment Station (WES), Corps of Engineers, U.S. Army, Vicksburg, Miss. Twelve $30.5-\mathrm{cm}$-diam by $30.5-\mathrm{cm}-1$ ong cylinders were cast, using the same concrete mixture that was used for the thermal cylinder model. Short sections of the 25.4-mm-OD stainless steel tubing used as moisture probe access tubes in the thermal cylinder model were cast into the center of each calibration specimen. The size of these specimens was chosen in accordance with recommendations made by the probe manufacturer.

The calibration procedure consisted of weighing the specimens and then taking a set of three independent 1-min probe counts immediately after casting and again after demolding (one day later). The demolded specimens were divided into four sets of three specimens each and placed in constantenvironment chambers maintained at a temperature of $297.0 \pm 1 \mathrm{~K}$ and having relative humidities of $100,90,80$, and $70 \%$, respectively. The specimens were removed from the chambers and weighed, and counts were made at 7, 28, $35,42,49,57,76,87$, and 112 days after casting. 


\section{ASSEMBLY AND CASTING}

\subsection{Assembly of Mode1}

The bottom support and insulating layers of the model were assembled, as shown in Fig. 1.3, to the sheet-metal moisture seal located directly above the asbestos cement board. A temporary support superstructure was then erected on the base support framework.

Panelcoil heat exchangers served both as the walls of the pressurization annulus (heat exchangers $A$ and $B$ ) and the outer wall of the test section (heat exchanger $C$ ) in addition to serving as the major part of the concrete formwork. An array of Nelson-type studs were attached to the surfaces of the two interior Panelcoils ( $A$ and $B$ ) to ensure that a good bond developed between the heat exchangers and the concrete. The B Panelcoil, which formed the inner surface of the test section, was also instrumented with 20 weldable strain gages and 5 thermocouples. The pressurization annulus was fabricated by welding the top of bottom tori to the A and B Panelcoils. The leads for instrumentation located inside the annulus passed through seals located in the upper torus. The resistance heater for the hot-spot test was attached at the lower third point of the $B$ heat exchanger. After leak testing, the assembled annulus was positioned inside the structural formwork and welded to the bottom moisture seal. Assembly of the upper support formwork was then completed, and the axial prestressing and moisture tubes were installed.

The single-filament-Lype concrete embedment strain gages, which are relatively delicate, were precast in the form of three-gage rosettes for protection against breakage. It was also necessary, for the same reason, to precast the ten pressure stress cell components consisting of individual single-filament-type strain gages attached to pressure diaphragms. The concrete embedment instrumentation was positioned along the four gaged secliuns shown in Fig. 2.1, which were located $90^{\circ}$ apart around the model. Three of the gaged sections can be seen in Fig. 3.1, which is a view of the mold assembly with the outer heat exchanger removed. Figure 3.2 shows a closeup of one gaged section. As shown in the figure, the gages were supported by clamps attached to tubes housing the longitudinal 


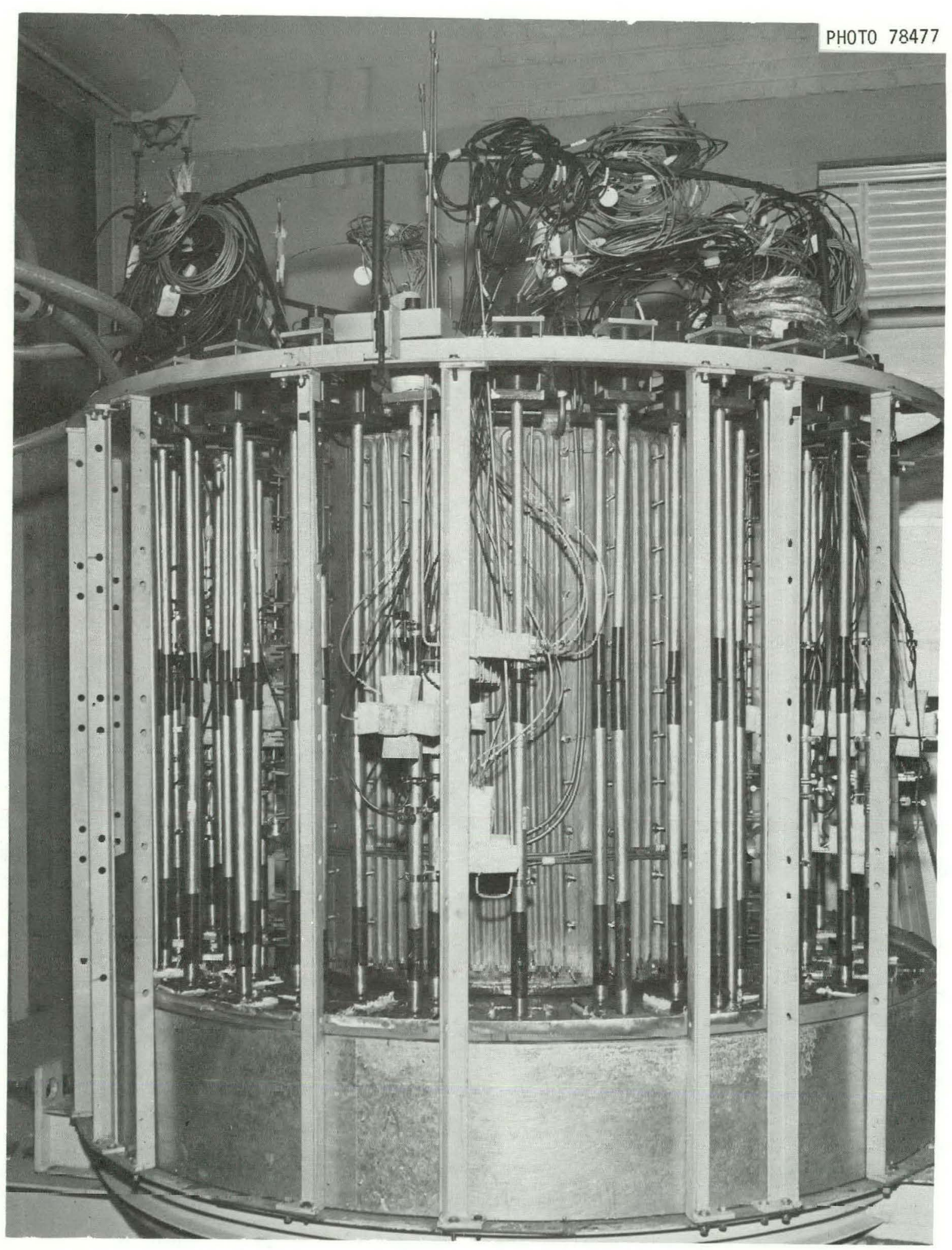

Fig. 3.1. Partially assembled mold with outer heat exchanger removed. 


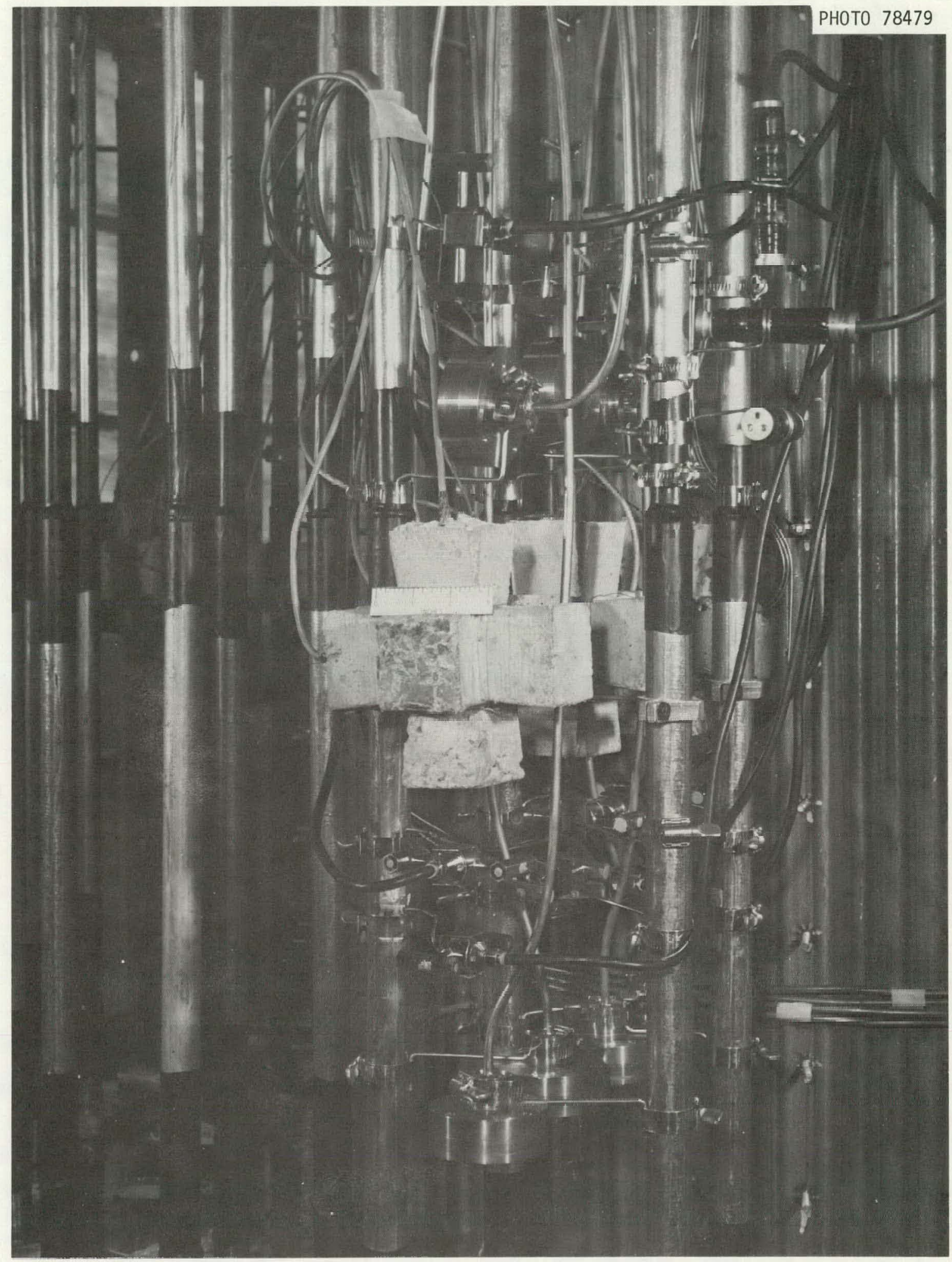

Fig. 3.2. Close-up of instrumentation at one of four gaged sections. 
prestressing. Shown in Fig. 3.2 from bottom to top are axial titanium stress cells; type A vibrating-wire strain gages; precast single-filament strain gage rosettes; and circumferential titanium stress cells, to the right of which are unbonded resistance strain gages. Axially oriented type A gages are shown at the top.

After the embedment instrumentation was installed, the outer heat exchanger was positioned and welded to the bottom moisture seal.

\subsection{Temperature- and Pressure-Contro1 Systems}

The temperature-control system consisted of two water-circulation loops - one for heating and one for cooling. The two loops were essentially the same except for inclusion of a water heater in the heating system. The hot-water loop supplied both interior heat exchangers ( $A$ and $B$ Panelcoils) from a common supply but at different flow rates; the coldwater system supplied the outer heat exchanger (C Panelcoil). Each loop was equipped with an extra pump to provide emergency backup and to allow for maintenance during periods of continuous operation. The assembled system and control instrumentation are shown in Fig. 3.3.

The annulus pressurization system consisted of four nitrogen bottles connected by a manifold to an oil expansion tank, which was in turn connected to the annulus of the model. During pressurization, the annulus and connecting line were filled with synthetic high-temperature hydraulic fluid to the level of the oil expansion tank. The applied pressure was controlled by the gas manifold pressure regulators.

\subsection{Casting of Model and Companion Specimens}

In addition to the thermal cylinder model, two $0.46-\mathrm{m}$-diam by $1.02-\mathrm{m}-$ long cylindrical molds were fabricated and assembled. These specimens contained representative instrumentation of every type used in the thermal cylinder.

The assembled model and molds were transported on a flatbed trailer, as shown in Fig. 3.4, to the casting site at WES in Vicksburg, Miss. In the figure, which shows the concrete placing operation in progress, part of the plastic and wooden protective covering has been removed. 


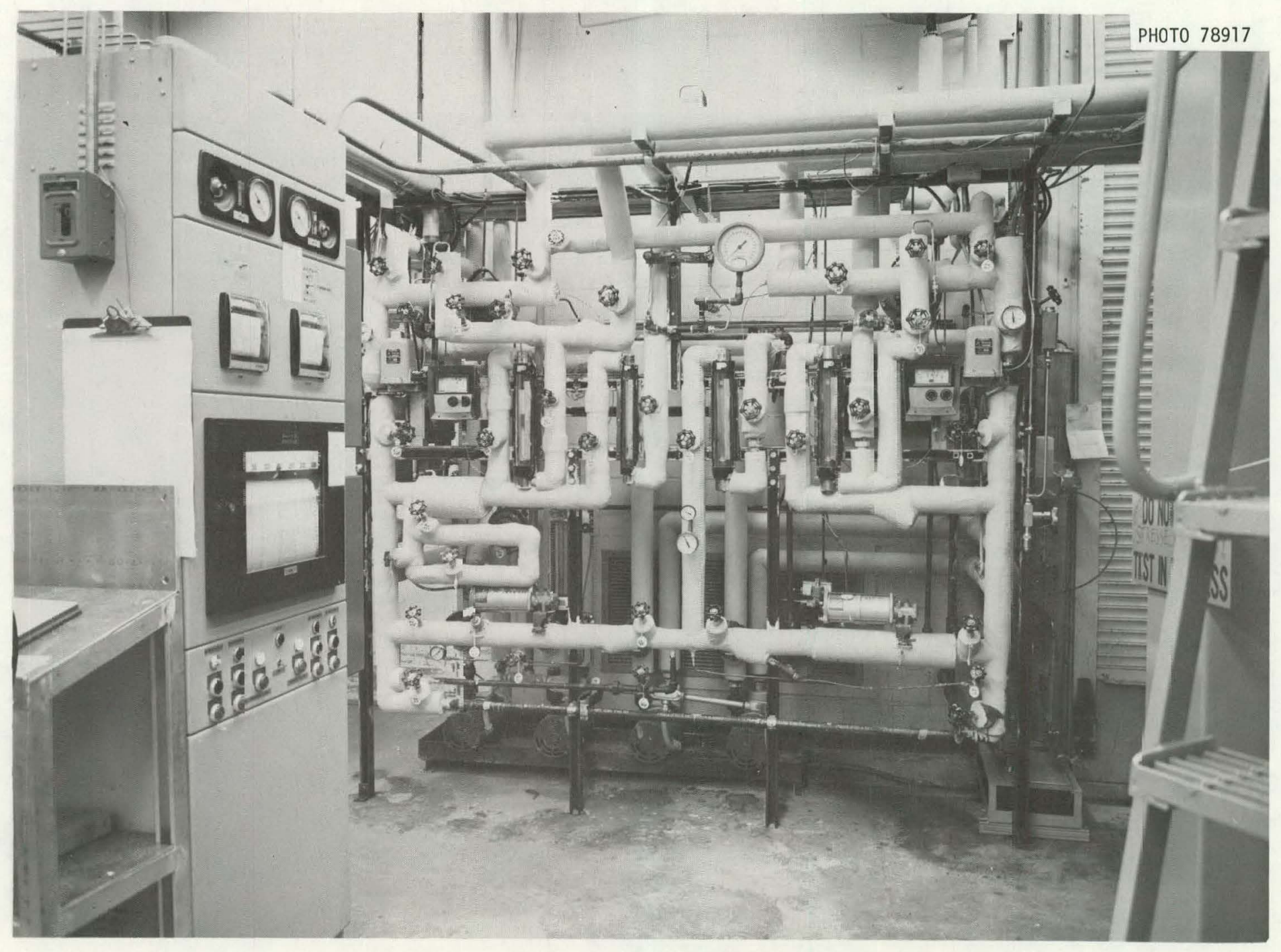

Fig. 3.3. Temperature control system. 


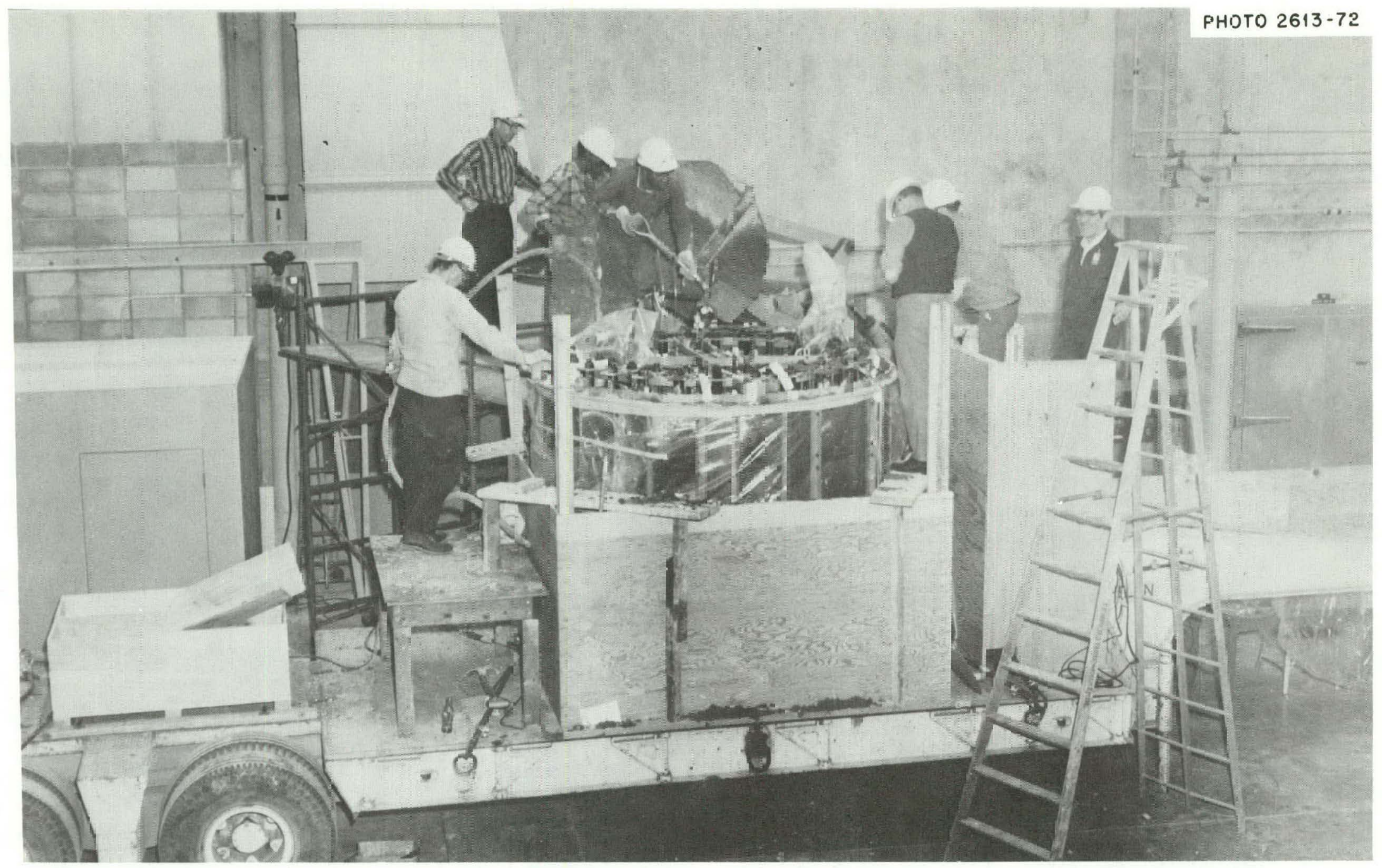

Fig. 3.4. Castins operation, showing plecing of concrete into thermal cylinder mold. 
The thermal cylinder, two $0.46-$ by $1.02-\mathrm{m}$ cylinders, and forty $0.15-$ by $0.30-\mathrm{m}$ standard compression specimens were cast, using fourteen $0.38-\mathrm{m}^{3}$ batches of the concrete mixture described in Table 3.1. This is the same concrete mixture used in the ORNL concrete program basic studies.

Upon completion of the finishing operation, the exposed concrete was covered with wet burlap to prevent overnight drying. The following day all exposed concrete was sealed using a combination of epoxy and copper sheeting.

After an initial 14-day curing period at WES, the trailer was returned to ORNL, where the specimens were prepared for testing. The water-circulaLion manifolds and related piping were installed, and the temperature-control system was set a $297 \mathrm{~K}$. With the exception of the vibrating-wire resistance strain gages and control thermocouples, the instrumentation was connnected to a 520-channel data-acquisition system.

Table 3.1. Thermal cylinder model concrete mixture

\begin{tabular}{|c|c|}
\hline Cement & Type 2 portland cement \\
\hline Aggregate & \\
\hline Type & Carter limestone \\
\hline Nominal maximum size, $\mathrm{cm}$ (in.) & $1.9(0.75)$ \\
\hline Gradation & $\begin{array}{l}\text { In accordance with ASTM } \\
\text { designation C33-67 }\end{array}$ \\
\hline$\frac{\text { Mixture proportions }}{\left(1-\mathrm{yd}^{3}\right) \text { batch] }}$ for $0.76-\mathrm{m}^{3}$ & \\
\hline Material/SSD ${ }^{\alpha}$ weight, kg (1b) & $\begin{array}{l}\text { Portland cement/309.1 }(681.5) \\
\text { Fine aggregate/626.6 (1381.5) } \\
\text { Coarse aggregate/809.4 (1784.4) } \\
\text { Water/176.9 (389.9) }\end{array}$ \\
\hline $\begin{array}{l}\text { Water-to-cement ratio, },^{b} \mathrm{~m}^{3} / \mathrm{sk} \\
(\mathrm{gal} / \mathrm{sk})\end{array}$ & $18.2 \times 10^{-3}(4.8)$ \\
\hline $\begin{array}{l}\text { Actual cement factor, },^{b} \mathrm{sk} / \mathrm{m}^{3} \\
\left(\mathrm{sk} / \mathrm{yd}^{3}\right)\end{array}$ & $9.48(7.25)$ \\
\hline Compressive strength, MPa (psi) & $41.37(6000) \pm 10 \%$ at 28 days \\
\hline
\end{tabular}




\section{TESTING}

\subsection{Concrete Strength Tests}

Seven of the standard compression specimens were tested at WES. The remainder of the $0.15-$ by $30-\mathrm{m}$ standard cylinders were transported in wet sawdust along with the thermal cylinder to ORNL, where compression tests were conducted at concrete ages of 28, 90, and 180 days. The results of these tests, together with the results of tests conducted at WES, are summarized in Table 4.1. The significant differences between 28-day compressive strengths of specimens tested at the two locations can be attributed to the 1 1/2 days of air drying required at WES for application of bonded strain gages. These differences are not seen when comparing ORNL 28-day strengths with WES trial batch results, where in both cases drying did not occur. A typical stress-strain curve and a plot of axial strain vs lateral strain are shown in Figs. 4.1 and 4.2 , respectively.

Table 4.1. Summary of thermal cylinder unconfined compression test results

\begin{tabular}{cccccc}
\hline $\begin{array}{c}\text { Dayo from } \\
\text { casting }\end{array}$ & $\begin{array}{c}\text { Number of } \\
\text { specimens }\end{array}$ & $\begin{array}{c}\text { Compressive } \\
\text { strength } \\
\text { [MPa (psi) }]\end{array}$ & $\begin{array}{c}\text { Modulus of } \\
\text { elasticlty } \\
{\left[\mathrm{GPa}\left(10^{6} \text { psi) }\right]\right.}\end{array}$ & $\begin{array}{c}\text { Poisson's } \\
\text { ratio }\end{array}$
\end{tabular} $\begin{array}{ccc}\text { Cure } & \text { Test } \\
\text { site }\end{array}$

Trial batch mixture

$\begin{array}{llll}28 & 10 & 46.8(6790) & \text { Wet WES }\end{array}$

Thermal cylinder concrete

\begin{tabular}{rlllllll}
7 & 3 & $34.4(4993)$ & & & Wet & WES \\
28 & 4 & $51.0(7390)$ & $31.0(4.5)$ & 0.26 & Wet & WES \\
28 & 3 & $46.3(6721)$ & $31.7(4.6)$ & & Wet & ORNL \\
90 & 6 & $60.8(8819)$ & $35.9(5.2)$ & 0.28 & Dry & ORNL \\
90 & 6 & $60.7(8804)$ & $37.9(5.5)$ & 0.31 & Wet & ORNL \\
180 & 4 & $62.7(9100)$ & $37.2(5.4)$ & 0.28 & Wet & ORNL \\
180 & 3 & $62.8(9115)$ & $37.9(5.5)$ & 0.26 & Dry & ORNL \\
\hline
\end{tabular}

${ }^{a}$ Wet - moist cured to time of testing; dry - moist cured for 28 days and air dried to time of testing. 


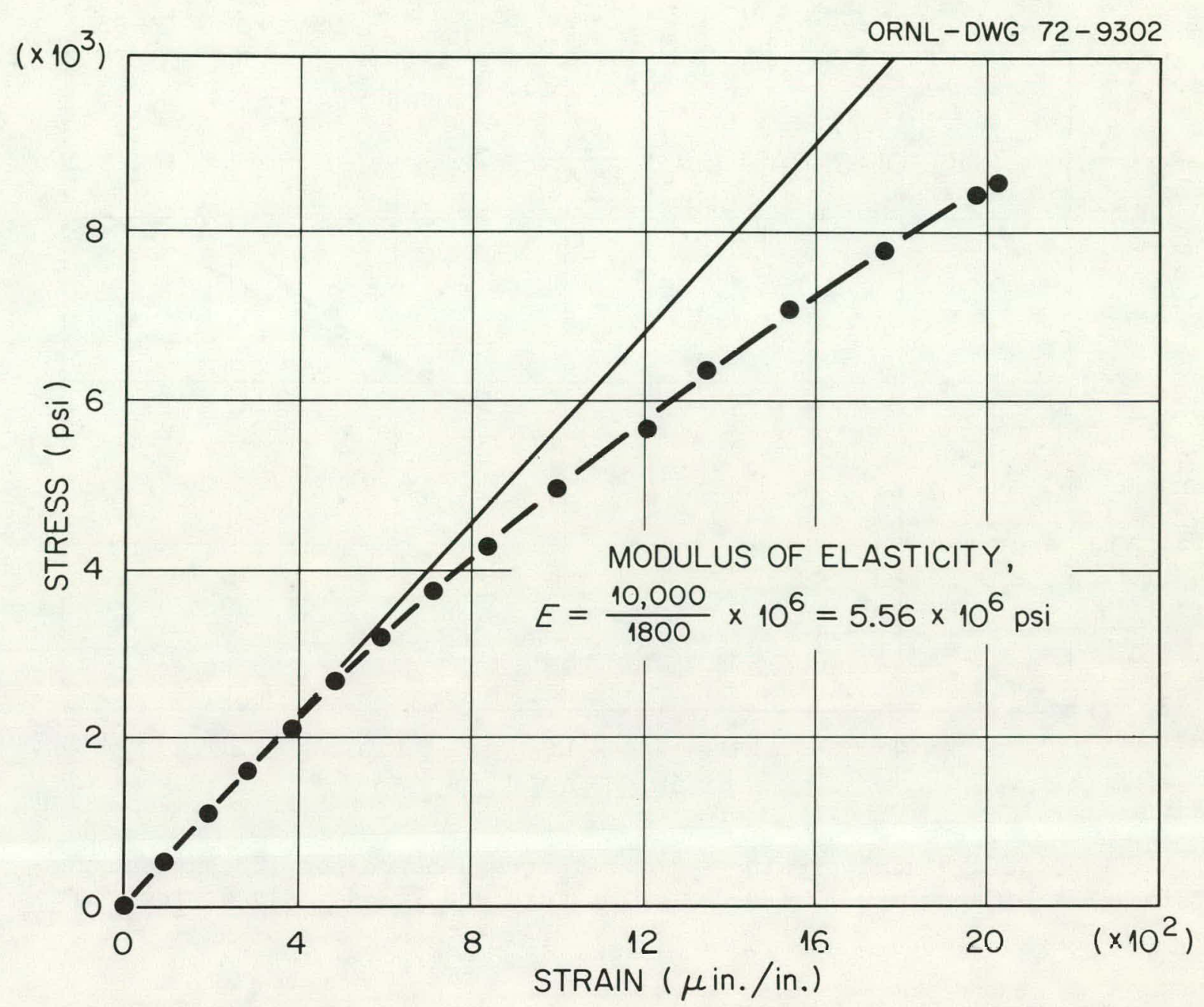

Fig. 4.1. Axial stress-strain curve for 180-day compression test of specimen 13 (28-day moist cure and 152-day air drying). $(1$ psi $=6895 \mathrm{~Pa}$.)

\subsection{Posttensioning of Mode1}

The thermal cylinder circumferential prestressing system was assembled after the specimen was installed at the ORNL test site. Posttensioning took place at a concrete age of 90 days. 'l'he circumferential tendons were stressed using seven 0.89-MN (100-ton) rams; six 0.27-MN (30-ton) rams were used to stress the axial tendons. The rams are shown positioned for posttensioning in Fig. 4.3. Each tendon was initially stressed to the halfload level, using a predetermined loading schedule. The schedule was then repeated, with the stress in each tendon being increased to the design 


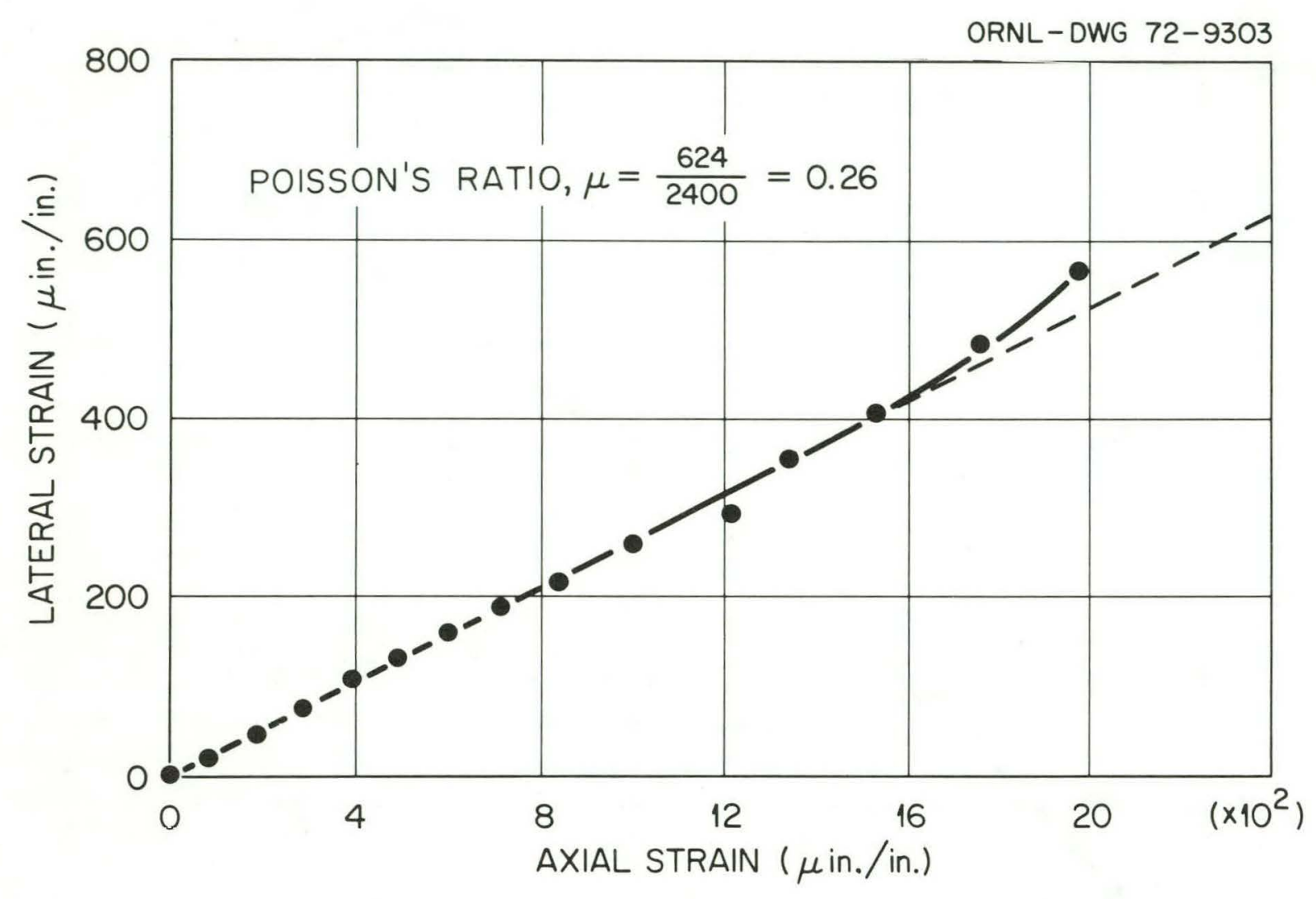

Fig. 4.2. Axial strain vs lateral strain curve for 180-day compression test of specimen 13 (28-day moist cure and 152-day air drying).

leve1. After the problems associated with localized crushing of the top moisture seal were solved, good agreement was seen between the loading applied to longitudinal tendons and the final loadings as indicated by the tendon transducers. Good agreement was also seen between the measured circumferential tendon strain and design values.

After posttensioning, the remaining phases of assembly, which consisted of installation of the upper insulation and moisture tube extensions and filling of the pressurizing annulus with hydraulic fluid, were completed. The completed model is shown in Fig. 4.4.

\subsection{Simulated Vessel Operation}

The scheduled heating phase of the experiment was initiated at a concrete age of 130 days. While the temperature of the outer heat exchanger 


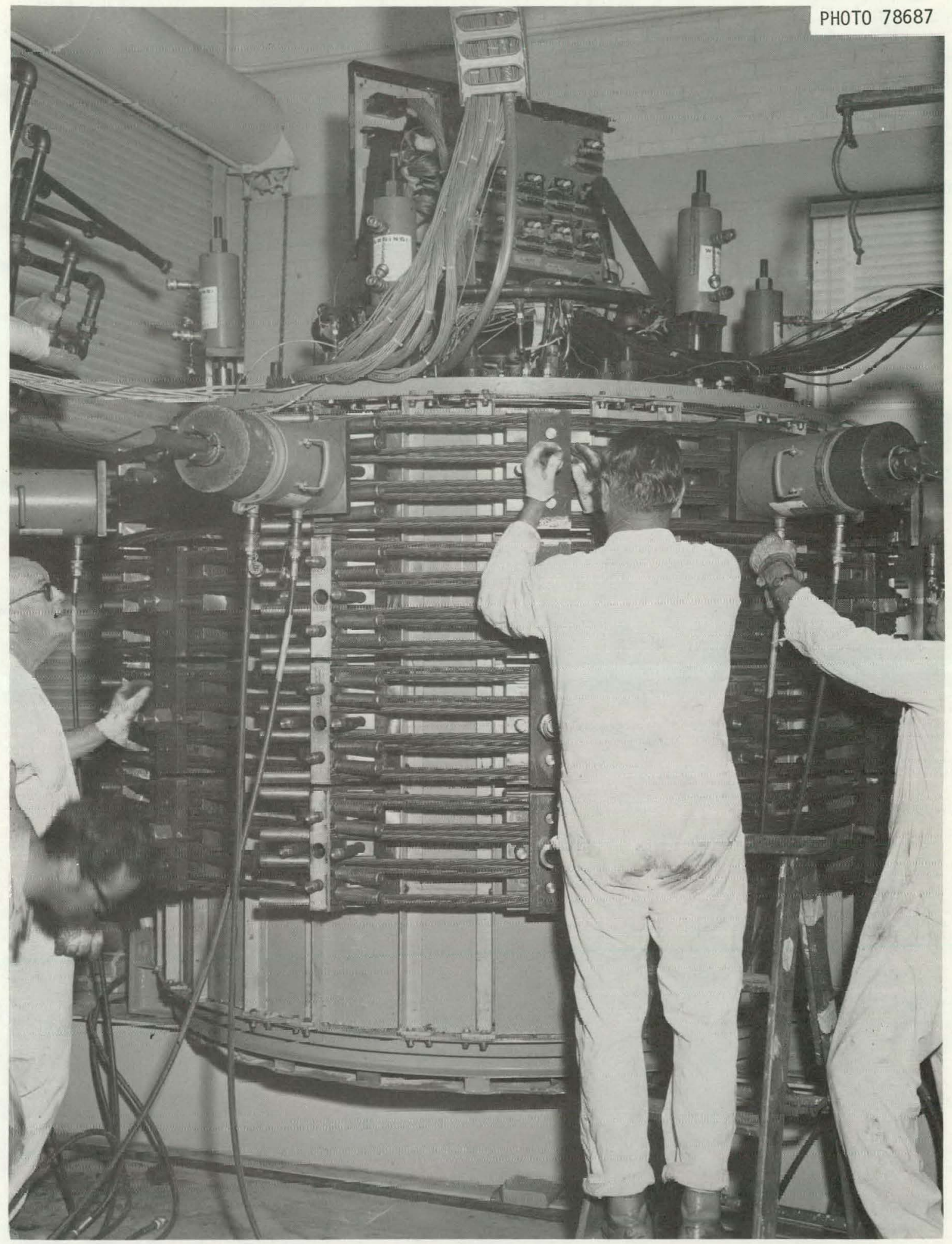

Fig. 4.3. Posttensioning operation, showing longitudinal and circumferential rams in position. 


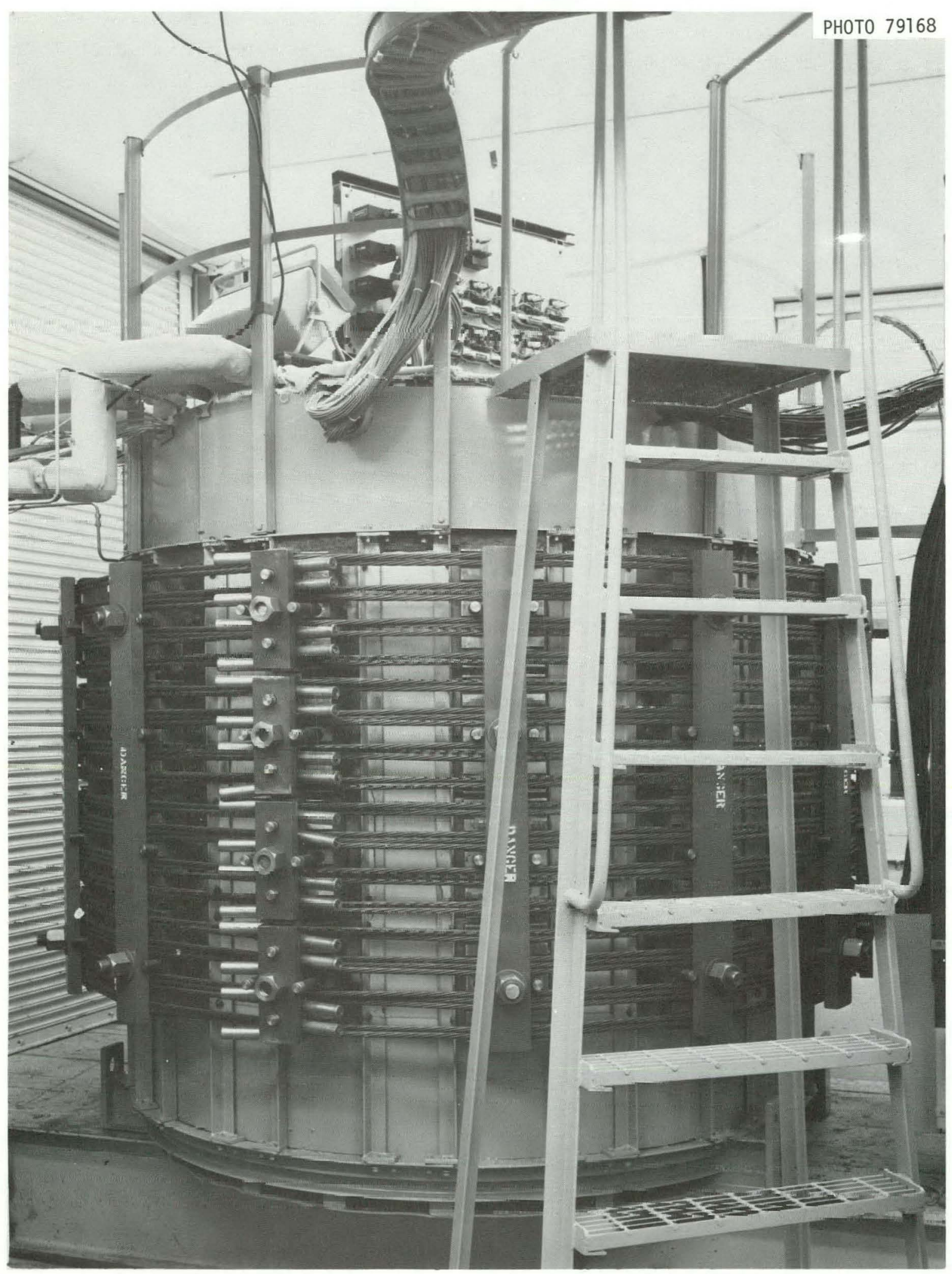

Fig. 4.4. Completed thermal cylinder model. 
was maintained at $297 \mathrm{~K}$, the temperature of the interior heat exchangers ( $A$ and $B$ Panelcoils) was increased at a rate of $2.8 \mathrm{~K}$ per day from the initial $297 \mathrm{~K}$ to a final value of $338.7 \mathrm{~K}$. The resulting through-the-wall thermal gradient shown in Fig. 4.5 was maintained for a period of approximately $141 / 2$ months as indicated in Fig. 1.2 .

In addition to the prestress loading and thermal gradient, the model was subjected to a $4.83-\mathrm{MPa}$ internal pressure by means of the annulus during the two time increments shown in Fig. 1.2. The initial 194-day pressurization period simulated normal PCRV operating conditions followed by a 146-day reactor shutdown.

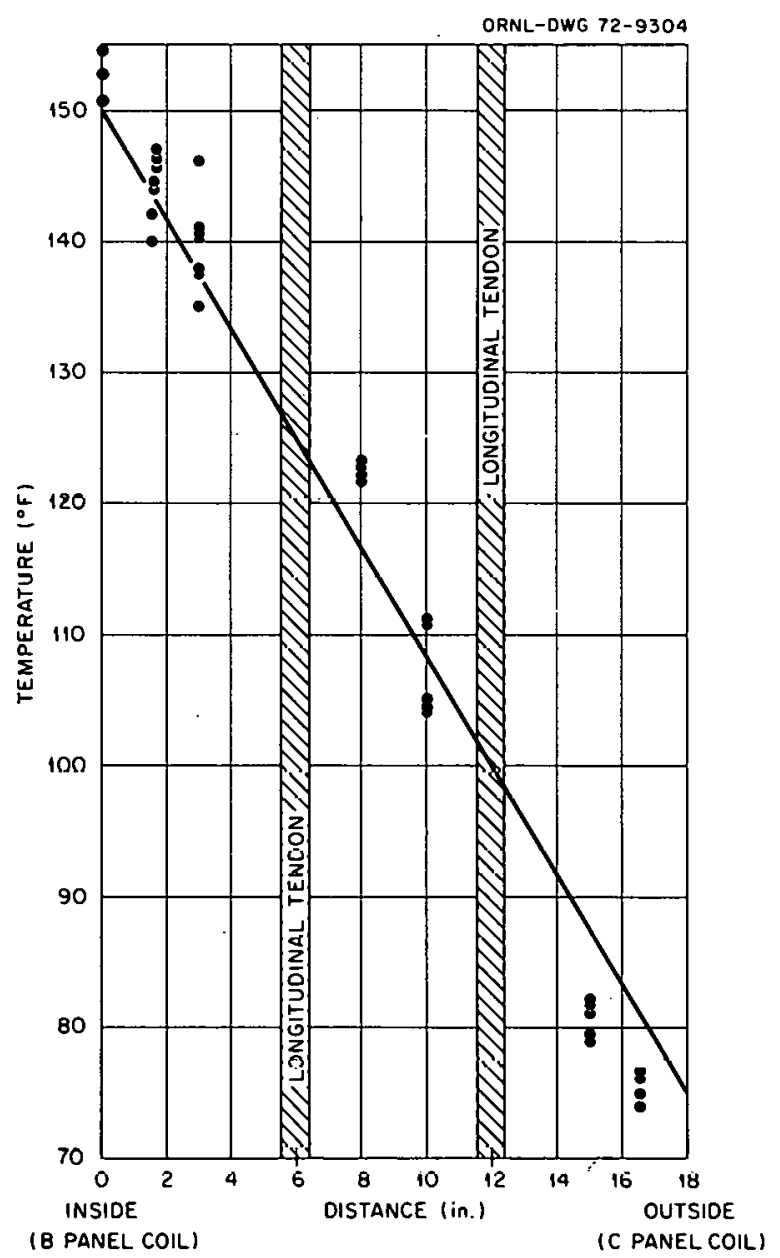

Fig. 4.5. Final thermal cylinder temperature gradient. Points indicate individual temperature readings of thermocouples and precision resistors. [1 in. $-25.4 \mathrm{~mm}$; $\left.\mathrm{K}=273.15+5 / 9\left({ }^{\circ} \mathrm{F}-32\right).\right]$ 


\subsection{Hot-Spot Test}

After the shutdown period, the 4.83-MPa pressure was reapplied and maintained for the duration of the hot-spot test. The inner water-circulation system was shut down, and two electric resistance heaters located on the concrete side of heat exchanger $B$ were activated 21 days after repressurization. After an initial two-week adjustment period, the temperature stabilized at the specified value of $505.4 \mathrm{~K}$ on the heater sheath and was maintained near that level for the 84-day duration of the test.

At the end of that period, the inner surface was cooled to $338.7 \mathrm{~K}$, using the inner water-circulation system, and eventually was cooled to $297 \mathrm{~K}$ in a second step. This temperature excursion simulates an off-design hot-spot condition in which the liner cooling system and/or the insulation is assumed to have failed in an operating nuclear reactor. 


\section{ANALYSIS}

A time-dependent creep analysis of the entire operational history of the thermal cylinder model was conducted using the SAFE-CRACK computer program $^{5}$ together with concrete materials properties data developed at the University of Texas $^{6}$ for the same basic concrete mixture. The original computer program was modified to include a new integration scheme and a new temperature treatment based on the shift principle. ${ }^{7}$ These improvements are most important in cases where the stress relaxation curve deviates appreciably from a straight line. The time-temperature shift treat-

ment is applicable to creep behavior only. In addition, the new integration scheme will permit the use of larger time steps in the analysis, although this was not needed at this time for analyzing the thermal cylinder model. The complete analysis employed 47 time steps covering 585 days from the completion of posttensioning.

The analytical model is the axisymmetric thick-walled cylinder shown in Fig. 5.1, having the dimensions and geometry of the test model. Both the cylinder and core are included in the finite-element grid. A total' of 564 elements are used, with triangular ring elements representing the concrete and membrane shell elements representing the liner or heat exchangers. The circumferential prestressing is represented as uniform pressure applied to the outer barrel section, and the axial prestressing tendons are treated as concentrated nodal loads. Once the specified failure criteria are exceeded, the affected concrete element is allowed to crack, and new stiffness and load matrices are computed in the analysis. The resulting new equilibrium equations are then solved for new displacements.

A heat transfer analysis was performed for the hot-spot condition to evaluate the temperatures that were measured during this overtemperature event. Internal and external boundary conditions and materials properties were varied to obtain the best fit of measured temperatures in the test specimen section. The material and heat transfer parameters that gave the best fit are listed in Table 5.1, and the recorded and predicted temperatures are shown in Fig. 5.2. The transport of heat by the synthetic fluid 

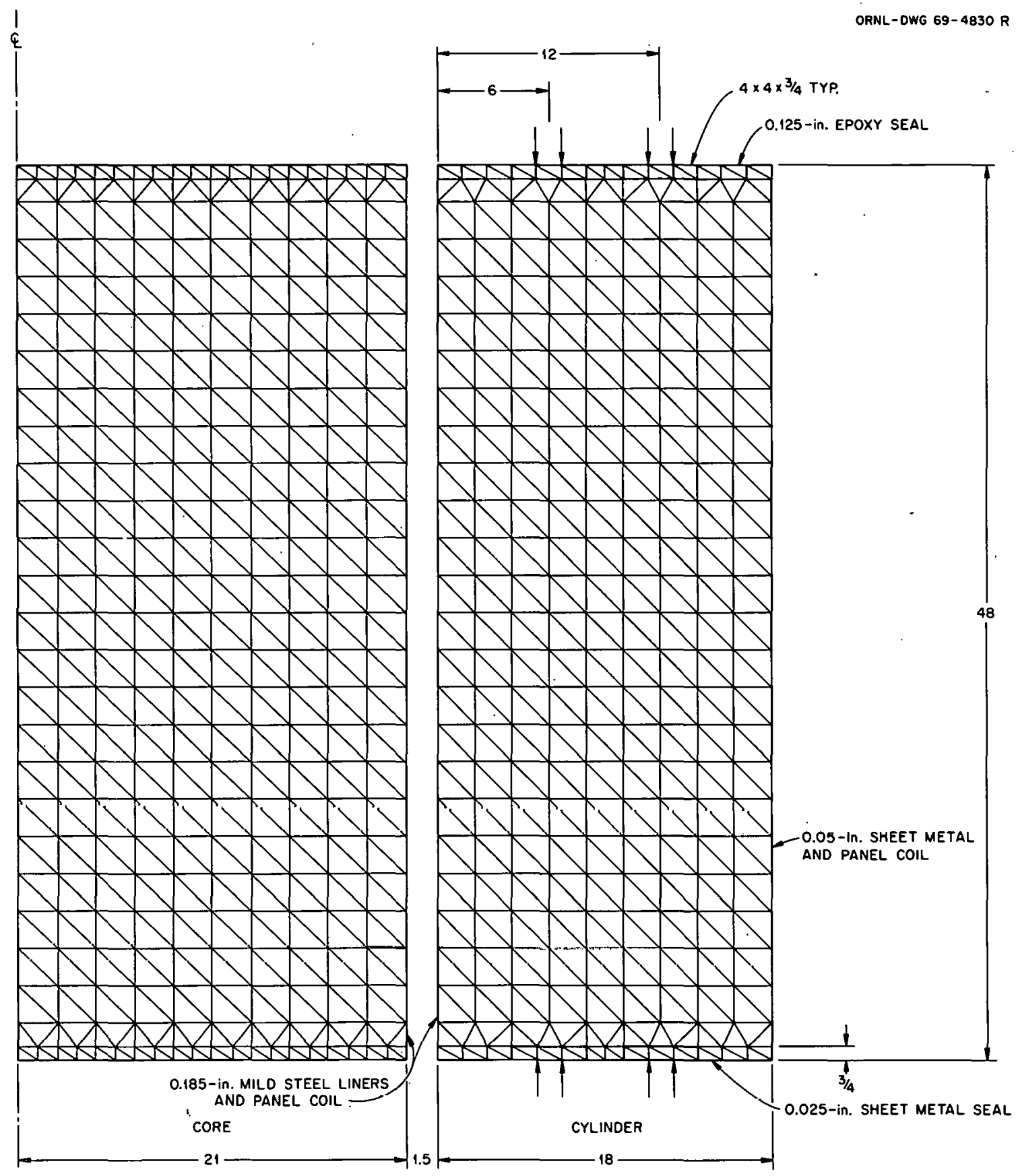

NOTE: DIMENSIONS ARE IN INCHES

Fig. 5.1. Axisymmetric finite-element layouts for thermal cylinder test section and core ( 1 in. $=25.4 \mathrm{~mm}$ ). 
Table 5.1. Macerial and heat transfer parameters for hot-spot analysis

Electric heater power, $3100 \mathrm{~W}$

Recorded sheath temperature, $505.3 \mathrm{~K}\left(450^{\circ} \mathrm{F}\right)$

\begin{tabular}{|c|c|c|c|}
\hline & Concrete & Oil & Water \\
\hline Density, $\mathrm{kg} / \mathrm{m}^{3}\left(1 \mathrm{~b} / \mathrm{ft}^{3}\right)$ & $2402.8(150.0)$ & $1414.4(88.3)$ & $961.1(60.0)$ \\
\hline $\begin{array}{l}\text { Thermal conductivity, } \mathrm{W}^{\prime} \mathrm{m} \cdot \mathrm{K} \\
{\left[\mathrm{Btu} \mathrm{hr}^{-1} \mathrm{ft}^{-1}\left({ }^{\circ} \mathrm{F}\right)^{-1}\right]}\end{array}$ & $2.86(1.65)$ & $0.118(0.068)$ & $0.69(0.4)$ \\
\hline $\begin{array}{l}\text { Specific heat, } \mathrm{J} / \mathrm{kg} \cdot \mathrm{K} \\
{\left[\text { Btu } 1 \mathrm{~b}^{-1}\left({ }^{\circ} \mathrm{F}\right)^{-1}\right]}\end{array}$ & $837.4(0.2)$ & $1172.3(0.28)$ & $4186.8(1.0)$ \\
\hline $\begin{array}{l}\text { Heat transfer coefficient, } \mathrm{W} / \mathrm{m} \cdot \mathrm{K} \\
{\left[\text { Btu hr } \mathrm{ft}^{-1}\left({ }^{\circ} \mathrm{F}\right)^{-1}\right]}\end{array}$ & & $a$ & $3459.1(2000)$ \\
\hline
\end{tabular}




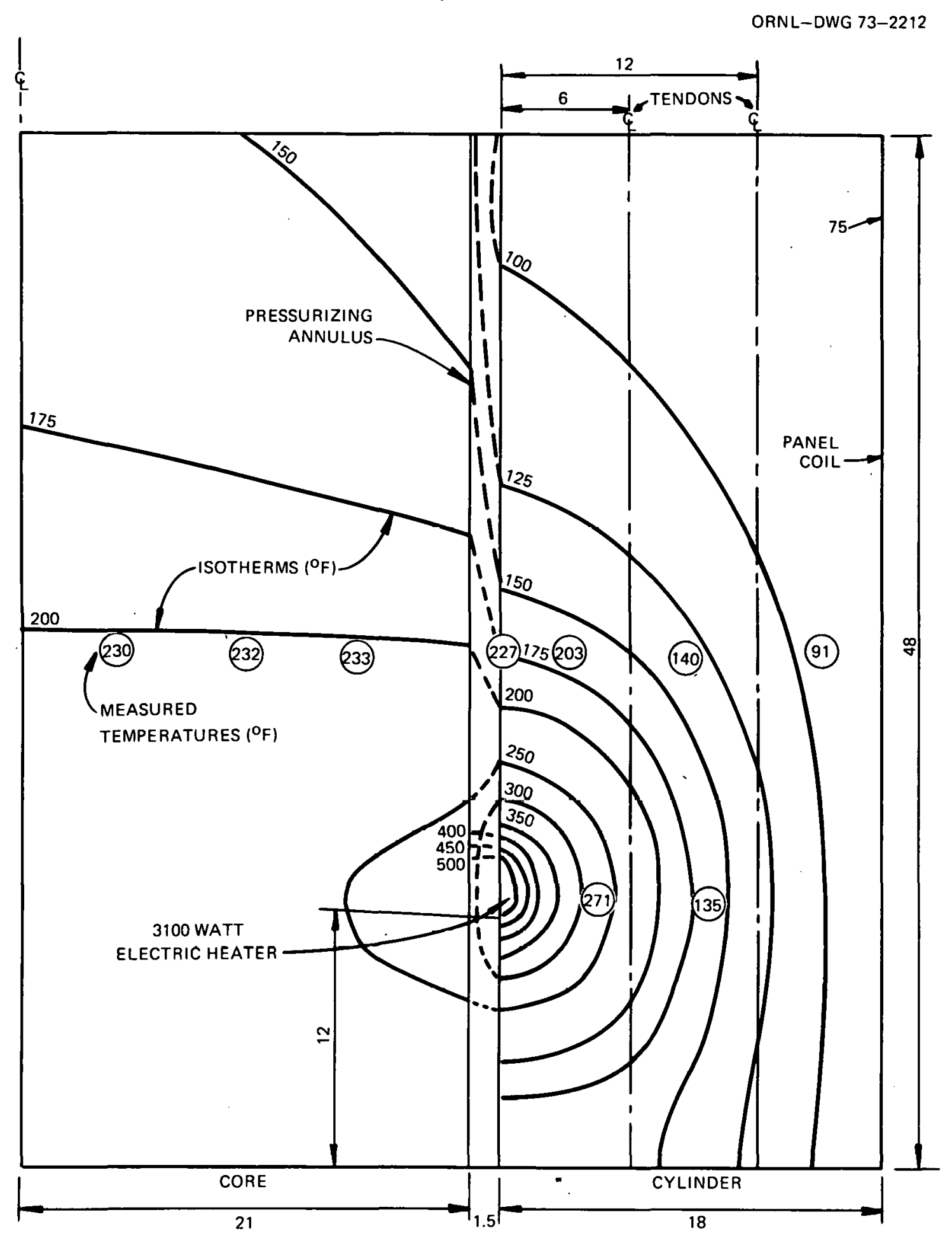

Fig. 5.2. Temperature profiles during thermal cylinder hot-spot test $\left[1\right.$ in. $\left.=25.4 \mathrm{~mm} ; \mathrm{K}=273.15+5 / 9\left({ }^{\circ} \mathrm{F}-32\right)\right]$. 
in the pressurizing annulus, the refluxing of water and steam in the inactive circulating-water heating coils, and the variation in properties of the concrete as a function of temperature made this analysis difficult. However, the agreement with experimental data is generally good.

. The results of the finite-element analysis are compared with the corresponding experimental results in the next chapter. 


\section{EXPERIMENTAL AND ANALYTICAL RESULTS}

The performance of the 155 gages included in the model is summarized in Table 6.1; however, no general conclusions can be reached on overali gage performance, since there were 11 gage types or installations, each having a different level of development or calibration at the time of selection and each having been installed and checked under widely varying conditions. The following sections discuss the relative performance of the various types of instrumentation. The strains shown in the various data plots have all been adjusted to eliminate thermal expansion.

Table 6.1. Thermal cylinder test gage survival

\begin{tabular}{lcccc}
\hline \multicolumn{1}{c}{ Gage type } & $\begin{array}{c}\text { Letter } \\
\text { designation }\end{array}$ & $\begin{array}{c}\text { Total } \\
\text { number }\end{array}$ & $\begin{array}{c}\text { Number } \\
\text { failed }\end{array}$ & $\begin{array}{c}\text { Percent } \\
\text { survival }\end{array}$ \\
\hline $\begin{array}{l}\text { Embedment gages } \\
\text { Single-filament resistance }\end{array}$ & EB & 47 & 18 & 61.7 \\
$\begin{array}{l}\text { Vibrating wire } \\
\text { Type A }\end{array}$ & D & 27 & 21 & 22.2 \\
Type B & P & 9 & 3 & 33.3 \\
Type C & GA & 1 & 1 & 0 \\
Wound-wire resistance & & 6 & 1 & 83.3 \\
Stress cells & T & 8 & 3 & 62.5 \\
I1tantum res1stance & PSC & 6 & 6 & 0 \\
Pressure diaphragm & & & & \\
Strain gages & & 19 & 6 & 68.4 \\
Weldable (liner) & CB & 12 & 3 & 75.0 \\
Axial tendons & CG & 8 & 0 & 100.0 \\
Circumferential tendons & & & & \\
Load cells & TR & 12 & 1 & 91.7 \\
Axial tendons & & 155 & 63 & 59.4 \\
$\quad$ Total & & &
\end{tabular}

\subsection{Embedment Strain Gages}

of the various concrete embedment gages, the single-filament resistance type provided the most consistent and interpretable data. The performance of the vibrating-wire gages varied markedly by type, which was due in part to a mismatch in readout equipment. 
Comparisons of analytical and experimental results for axially and radially oriented gages located in position 1 are given in Figs. 6.1 and 6.2, respectively. (See Sect. 2.1 for a complete explanation of gage and position designations.) In both cases, the prestressing and pressurization strains were overestimated, while strains produced during heatup were underestimated. The behavior of the axial gages during hot-spot heating appears erratic, since a strain jump was recorded shortly after repressurization. The probable causes of this effect as well as the sharp fluctuations in analytical values are discussed in Chap. 7.

The calculated and experimental results for gages in the second rosette position are given in Figs. 6.3 to 6.5 . The same behavioral trends seen for the gages in position 1 were recorded by these gages as well, with the prestressing and pressurization strains being overestimated and the heatup strains underestimated. As expected, the recorded strains during hot-spot heating were less deviant, since these gages were farther away from the heated zone (center rosette position of Fig. 2.1). However, significant strain jumps were again monitored by the axial gages, and the analytical curves showed sharp fluctuations during hot-spot heating.

Single-filament-type embedment strain gages were also positioned in the concrete directly adjacent to the hot-spot heaters, as shown in Fig. 2.1 for the " $D$ " section. In Figs. 6.6 and 6.7, calculated and experimental results are compared for radial and circumferential gages at the hot spot. The prestressing strains agreed exceptionally well for these two gages, although, as seen previously, the initial heatup strains differed significantly from the calculated values and the experimental pressurization strains were consistently low. With the exception of three questionable calculated data points in Fig. 6.6, the experimental and analytical curves followed each other exceedingly well during the hot-spot test.

Average comparisons for the type A vibrating-wire strain gages in radial position 1 (see Fig. 2.1) are shown in Figs. 6.8 to 6.10 for axial, radial, and circumferential directions, respectively. The same general trends discussed for the single-filament-type gages shown in Figs. 6.1 and 6.2 were recorded by this entirely different type of concrete embedment strain gage, which was cast directly into the concrete of the thermal 


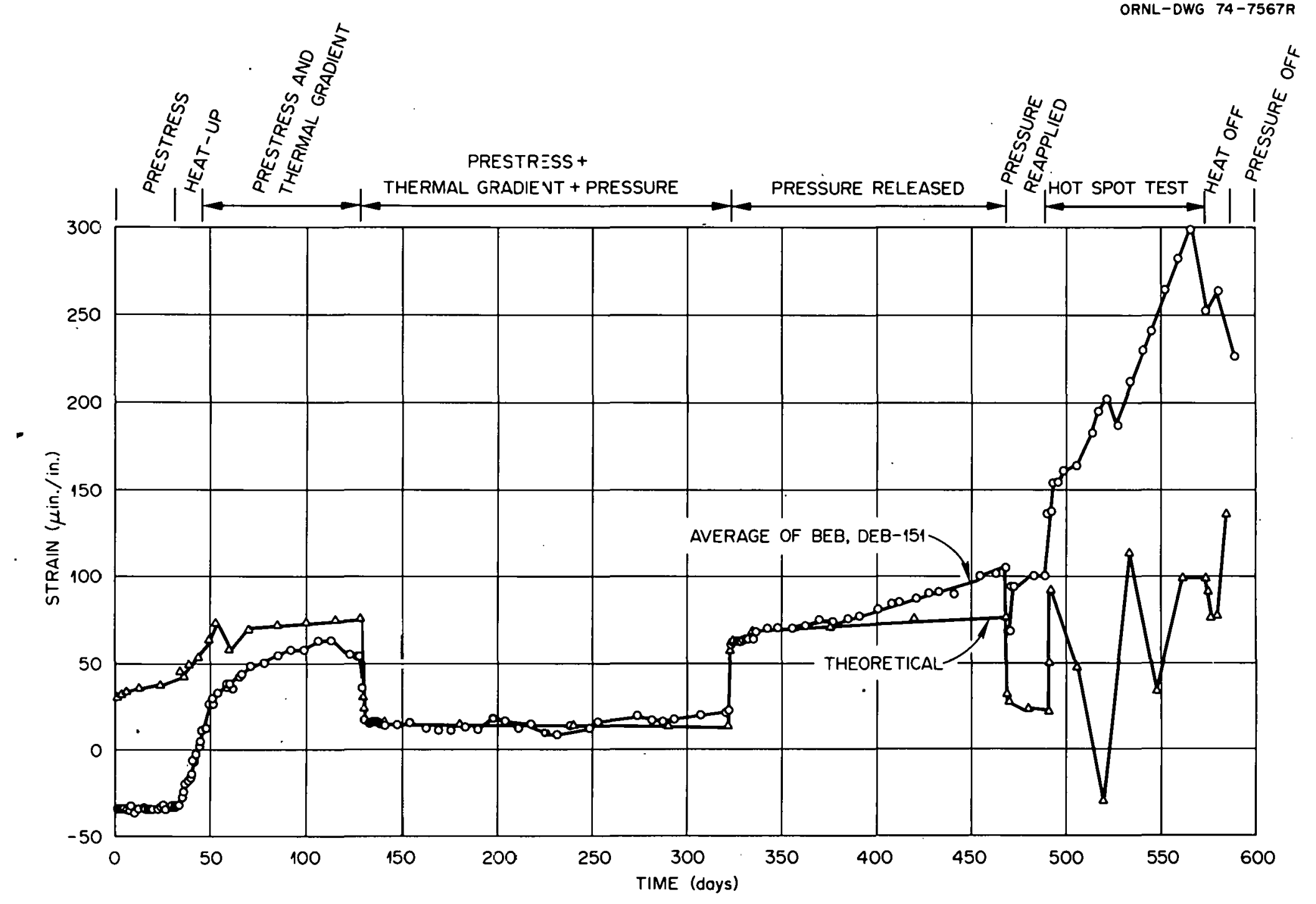

Fig. 6.1. Calculated and experimental results for first-position axial single-filament resistance strain gages. 


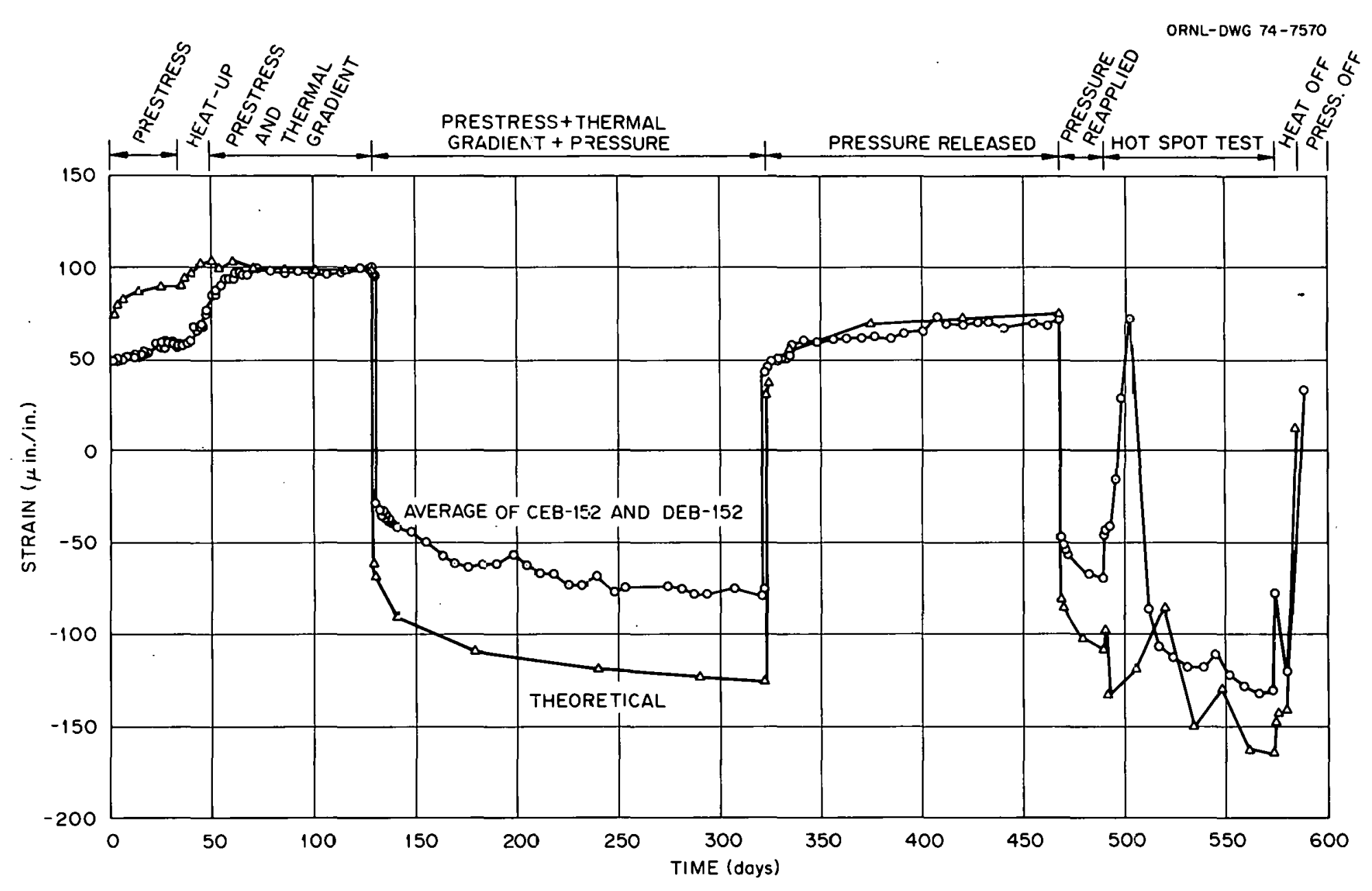

Fig. 6.2. Calculated and experimental results for first-position radial single-filament resistance strain gages. 


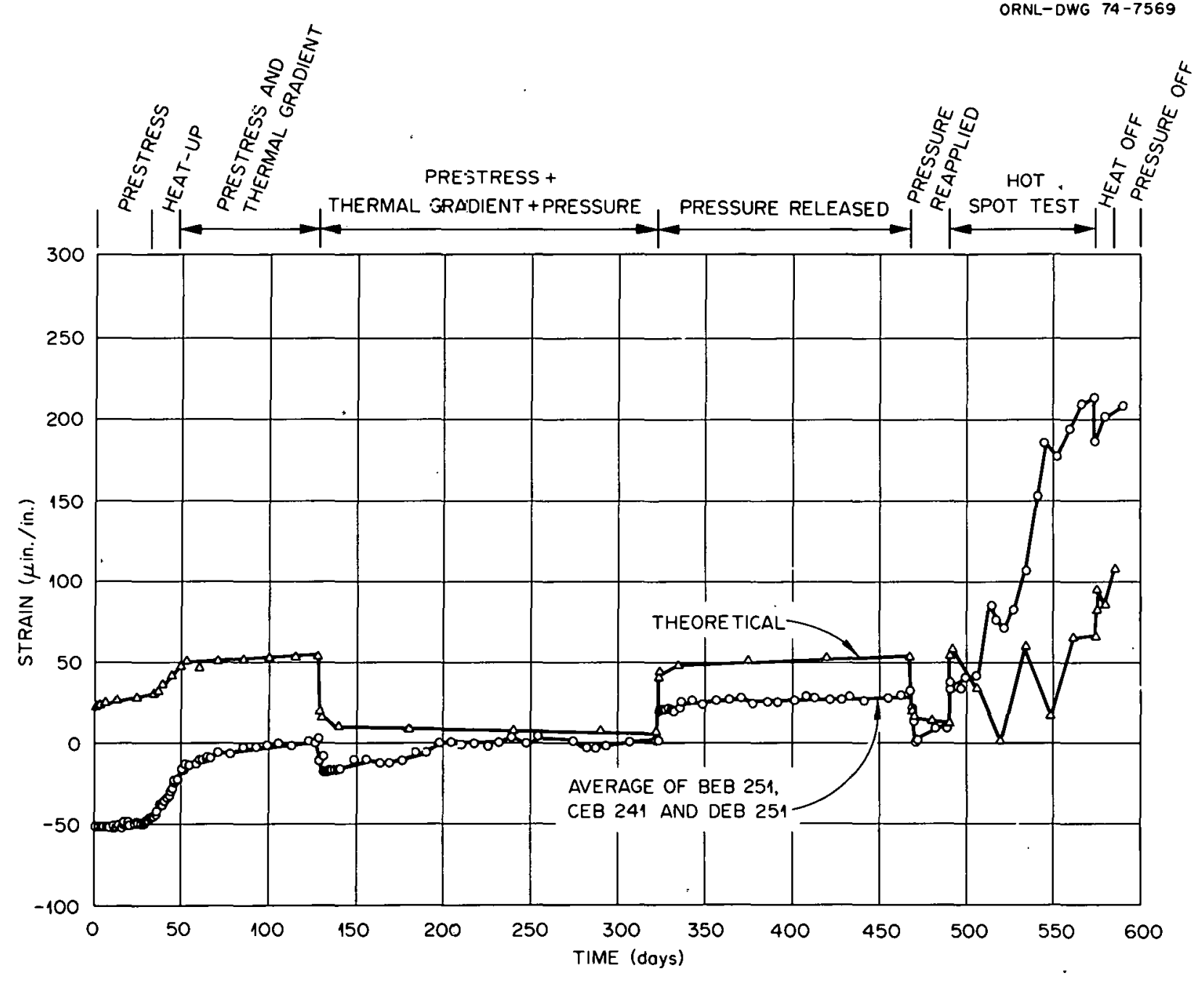

Fig. 6.3. Calculatel and experimental results for second-position axial single-filament resistance strain gages. 


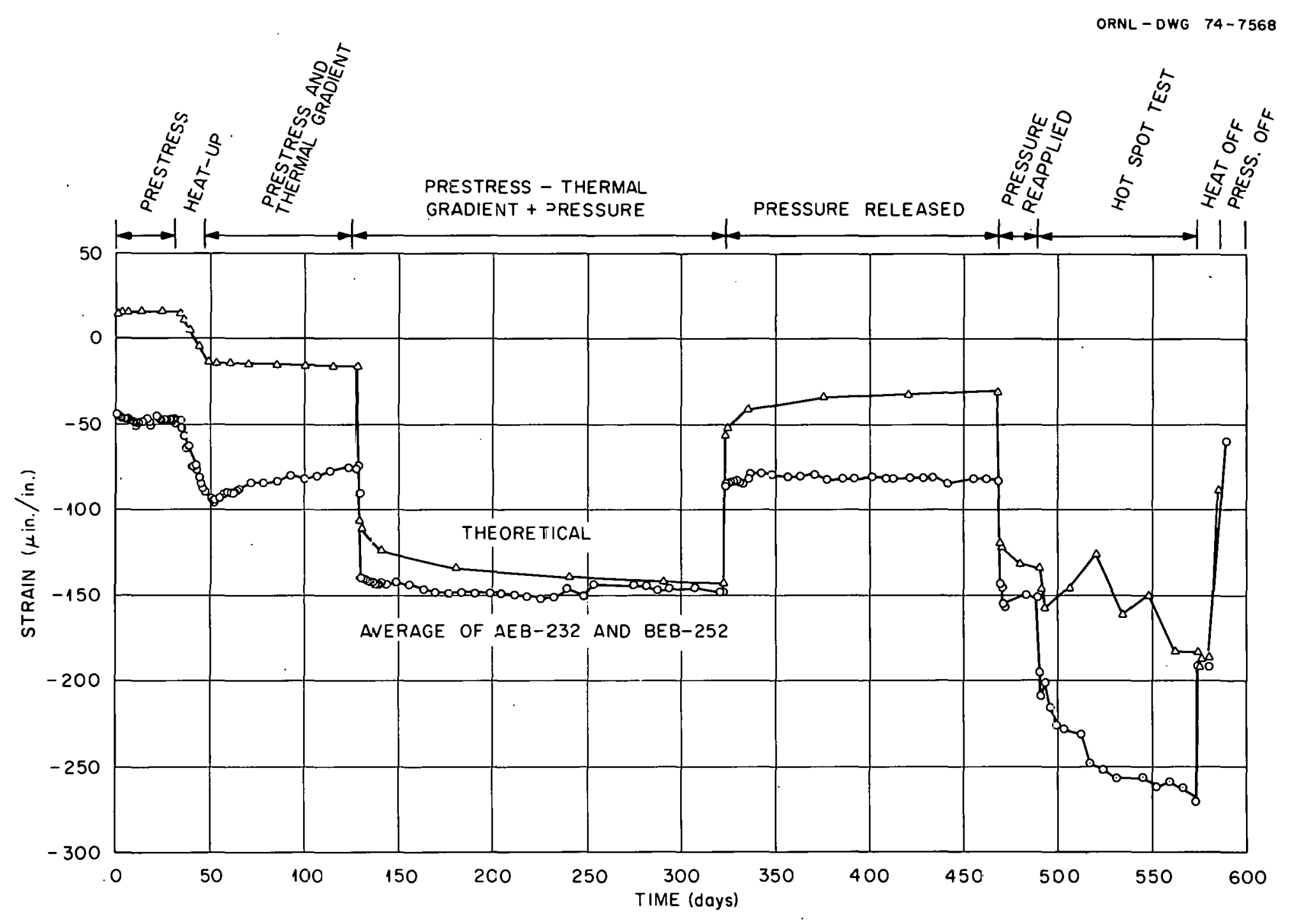

Fig. 6.4. Calculated and experimental results for second-position radial single-filament resistance strain gages. 


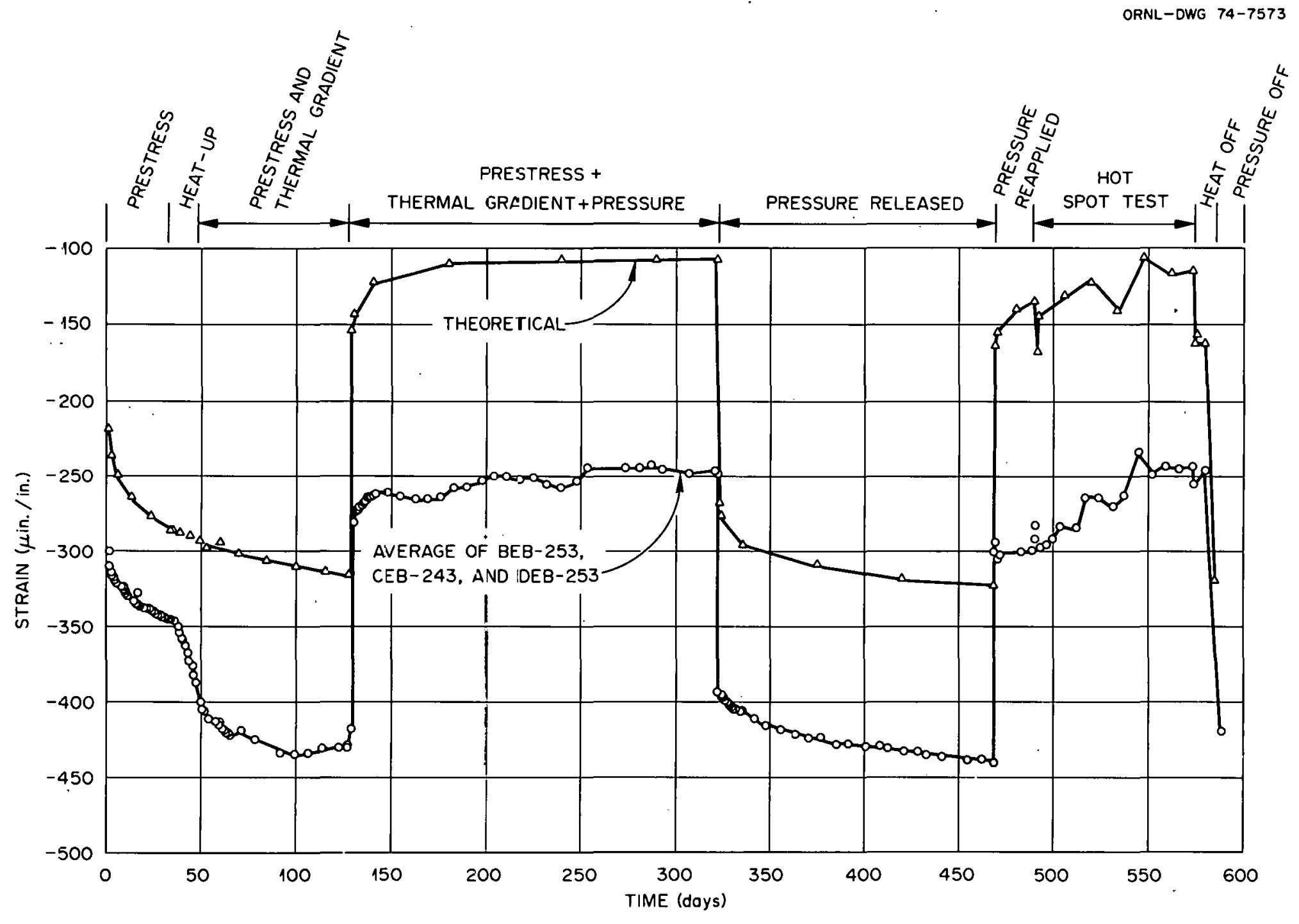

Fig. 6.5. Calculated and experimental results for second-position circumferential single-filament resistance strain gages. 


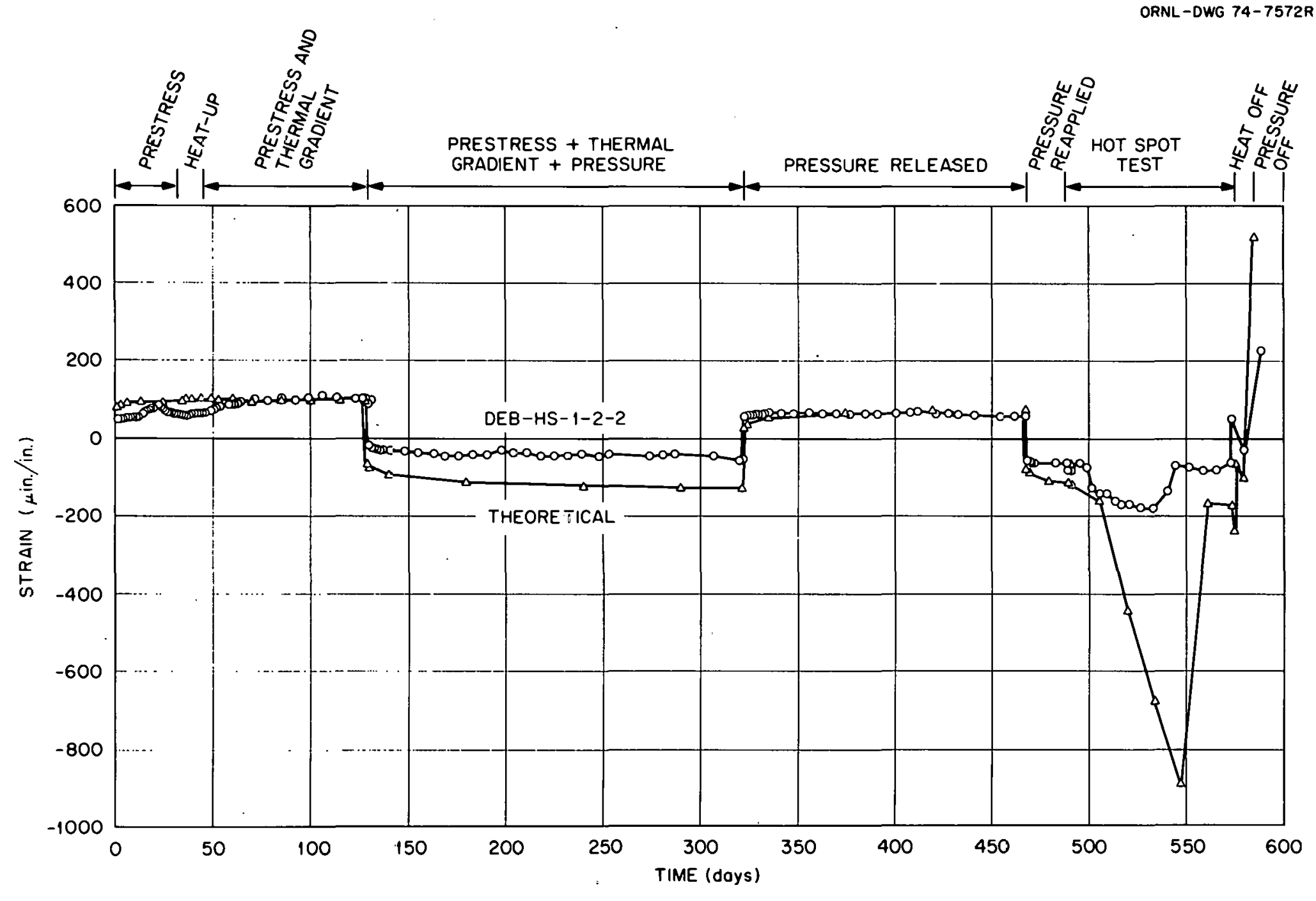

Fig. 6.6. Calculated and experimental results for hot-spot-position radial single-filament resistance strain gage. 


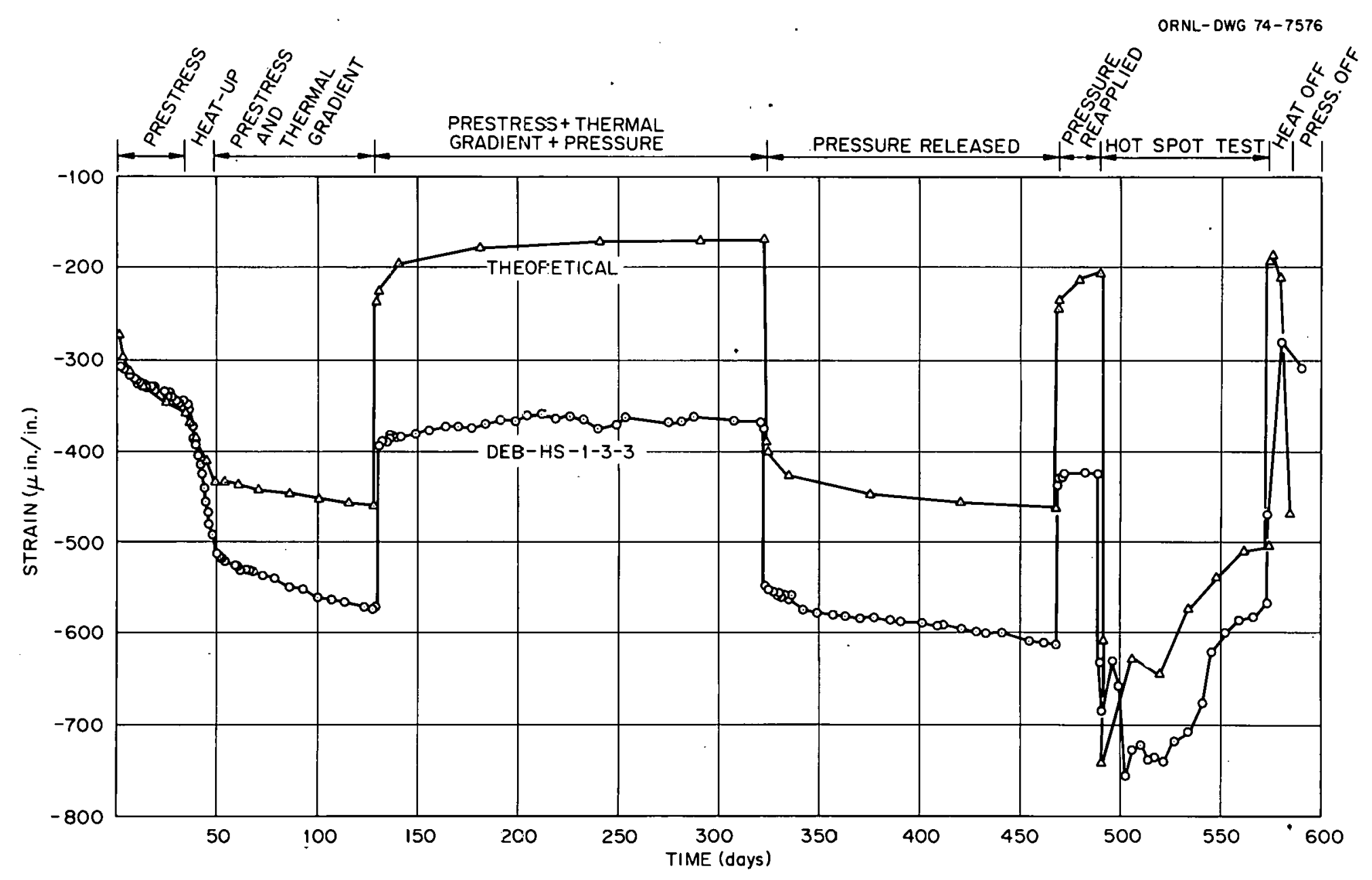

Fig. 6.7. Calculated and experimental results for hot-spot-position circumferential single-filament resistance strain gage. 


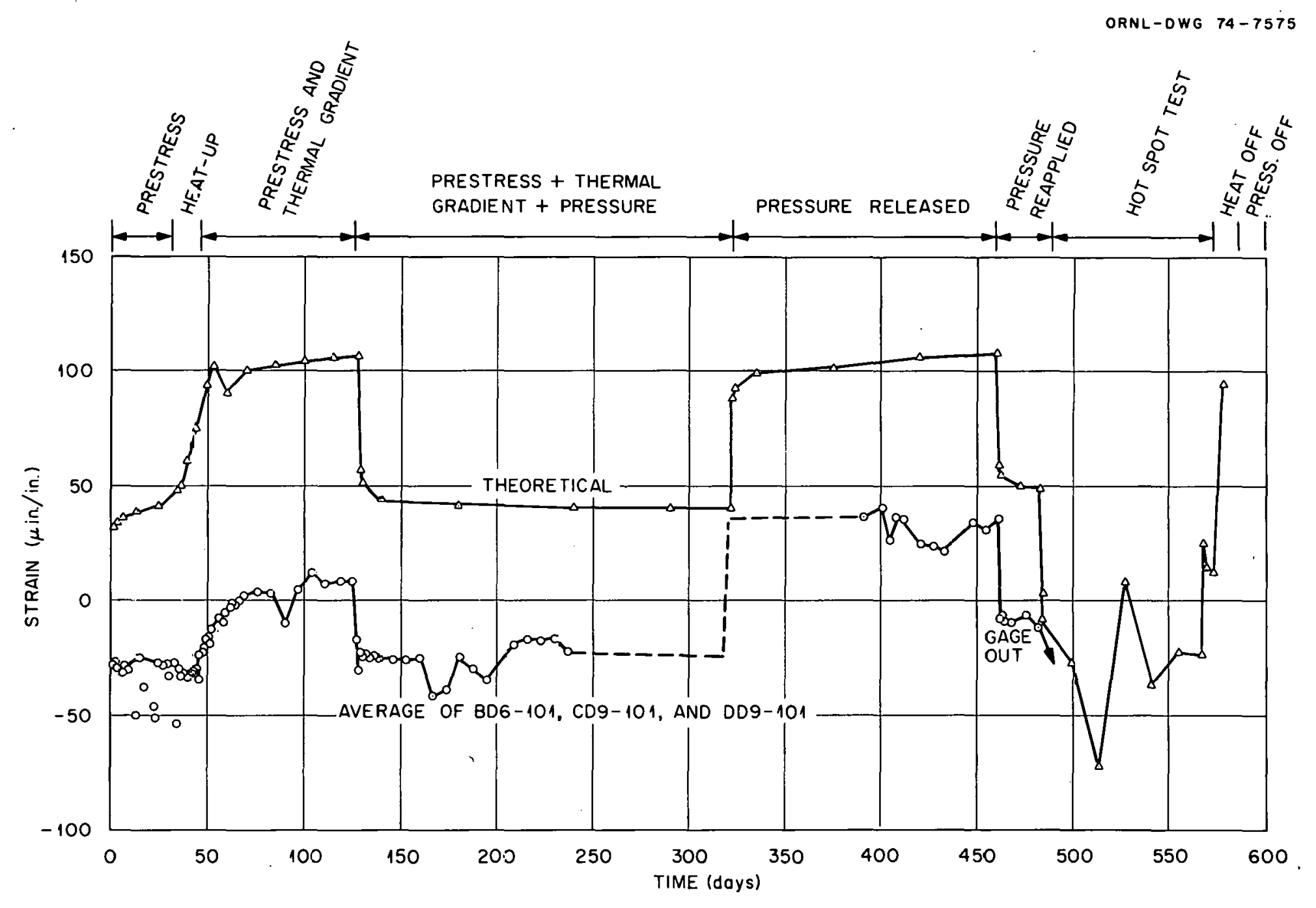

Fig. 6.8. Calculated and experimental results for first-position. axial type A vibrating-wire strain gages. 


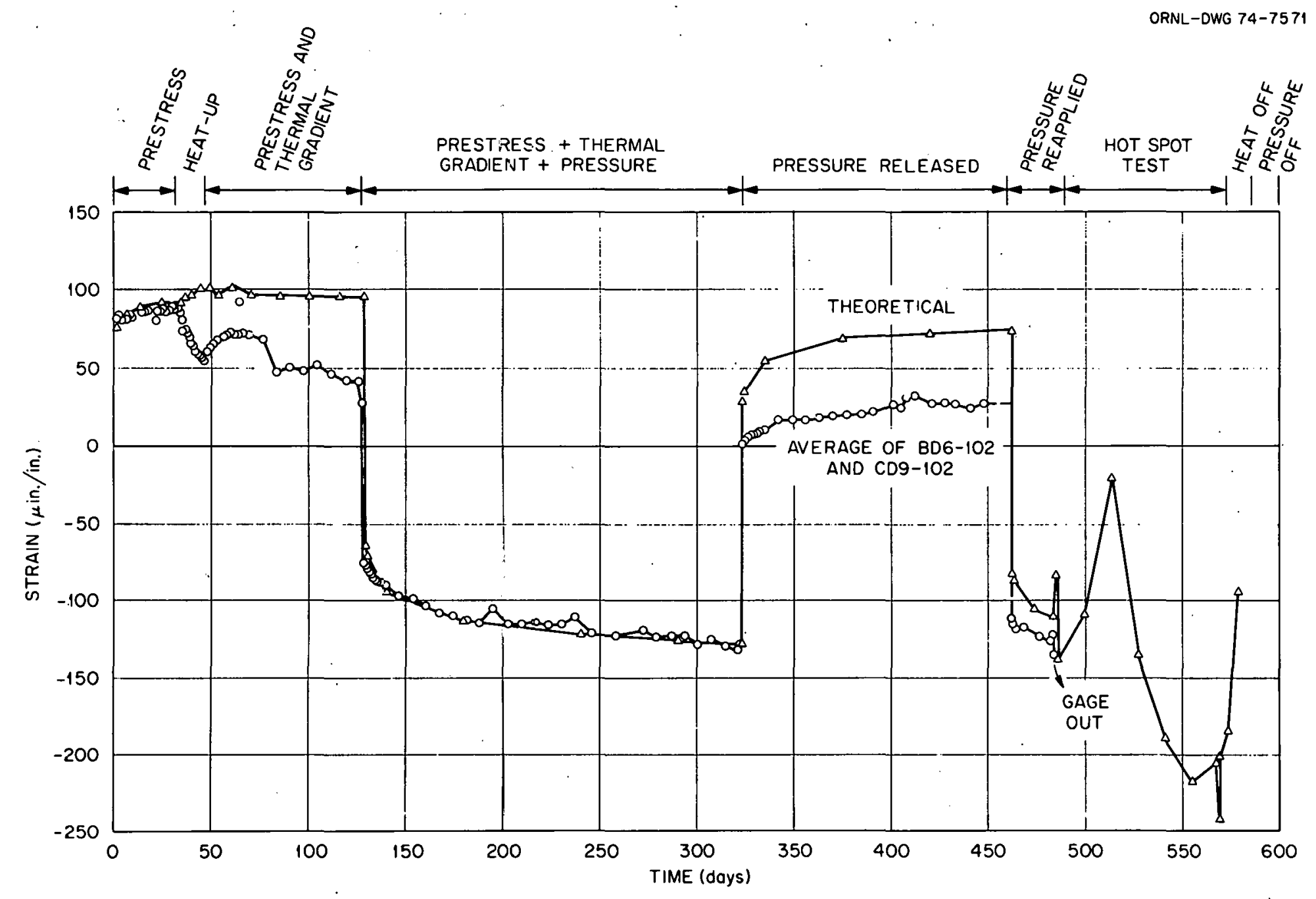

Fig. 6.9. Calculated and experimental results for first-position radial type A vibrating-wire strain gages. 


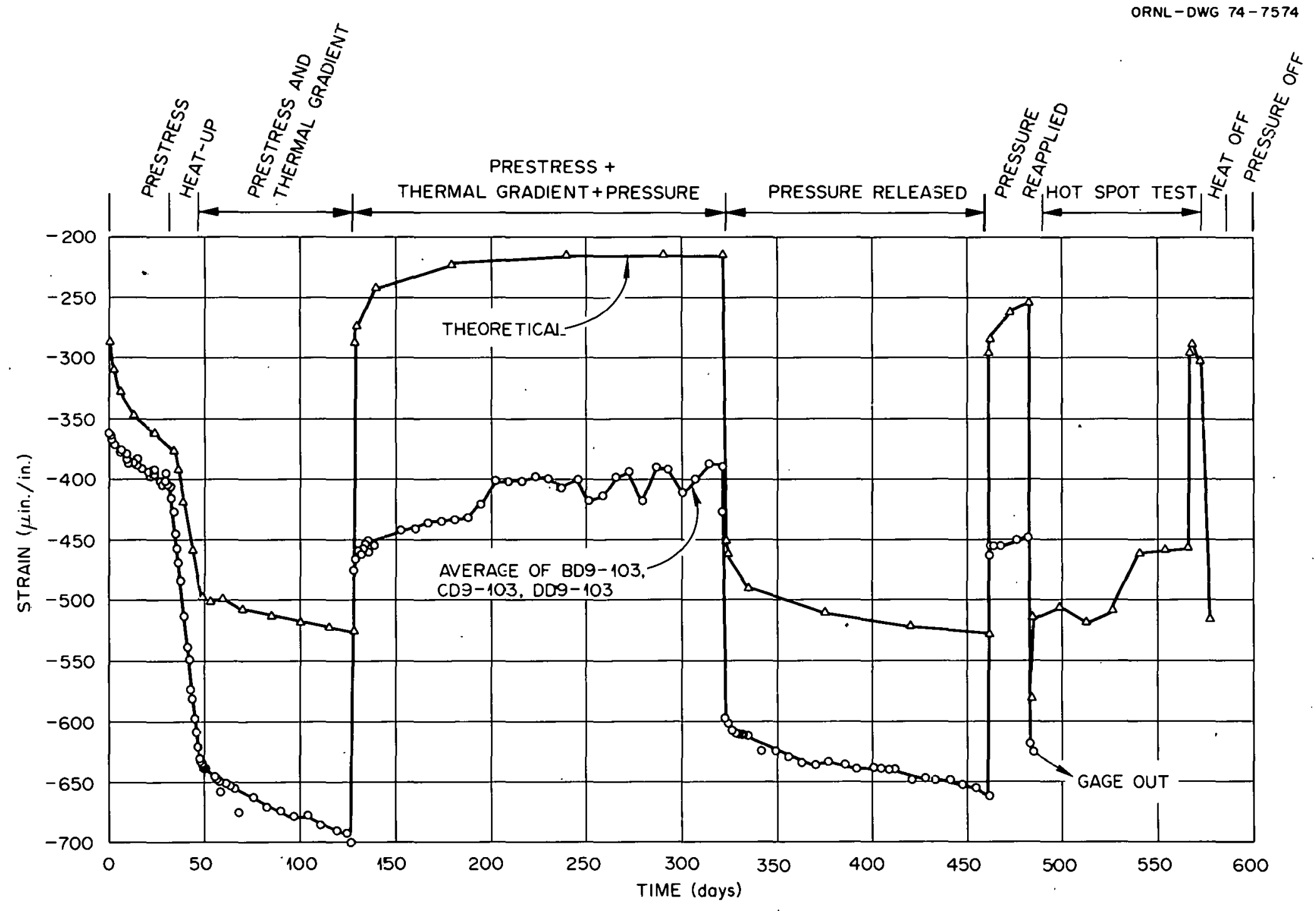

Fig. 6.10. Calculated and experimental results for first-position circumferential type A vibrating-wire strain gages. 
cylinder model; that is, there was overestimation by the analyses of prestressing and pressurization strains and underestimation of heatup strains. Since the vibrating-wire strain gages will function satisfactorily only at temperatures less than $\sim 340 \mathrm{~K}$, the gages failed at the beginning of the hot-spot test. The missing data from 240 to 390 days (see Fig. 6.8) was caused by problems with the gage readout equipment. Although four vibrating-wire gage positions were used across the test section, the position 3 gage results (shown in Fig. 6.11) can be compared from the behavioral standpoint with the single-filament gage data shown in Fig. 6.5; the same basic differences between experimental and analytical results are seen for both gage types.

of the nine type $B$ vibrating-wire embedment strain gages used in the model, six continued to operate during the experiment; however, the readings in many cases were inconsistent because of problems with the readout equipment. The vibrating-wire gage frequency monitor used for the study was designed specifically for use with type A gages and frequently gave inconsistent readings when used with type $B$ and $C$ gages.

Comparisons for two circumferential type $B$ gages are given in Figs. 6.12 and 6.13 for the first and second gage positions. Although better agreement occurred for prestressing strains, the same basic trends are again seen for this gage type; that is, the calculated strains during pressure steps are larger and the heatup strains smaller than the experimental values.

Only one of the type $C$ vibrating-wire strain gages was included in the model. Although this gage is far superior in basic design than the other two types of vibrating-wire gages, it requires precasting to ensure satisfactory performance. (This was not done in this experiment.)

The wound-wire resistance embedment strain gages also failed to perform satisfactorily, although all but one remained operational during the experiment. (However, the gages of this type used in the companion concrete specimens functioned satisfactorily.) The unsatisfactory performance of these gages is attributed to the absence of bonding between gage and concrete. It is felt that the present gage deficiency could be corrected with only minor modifications of the bonding surfaces of the gage housing. 


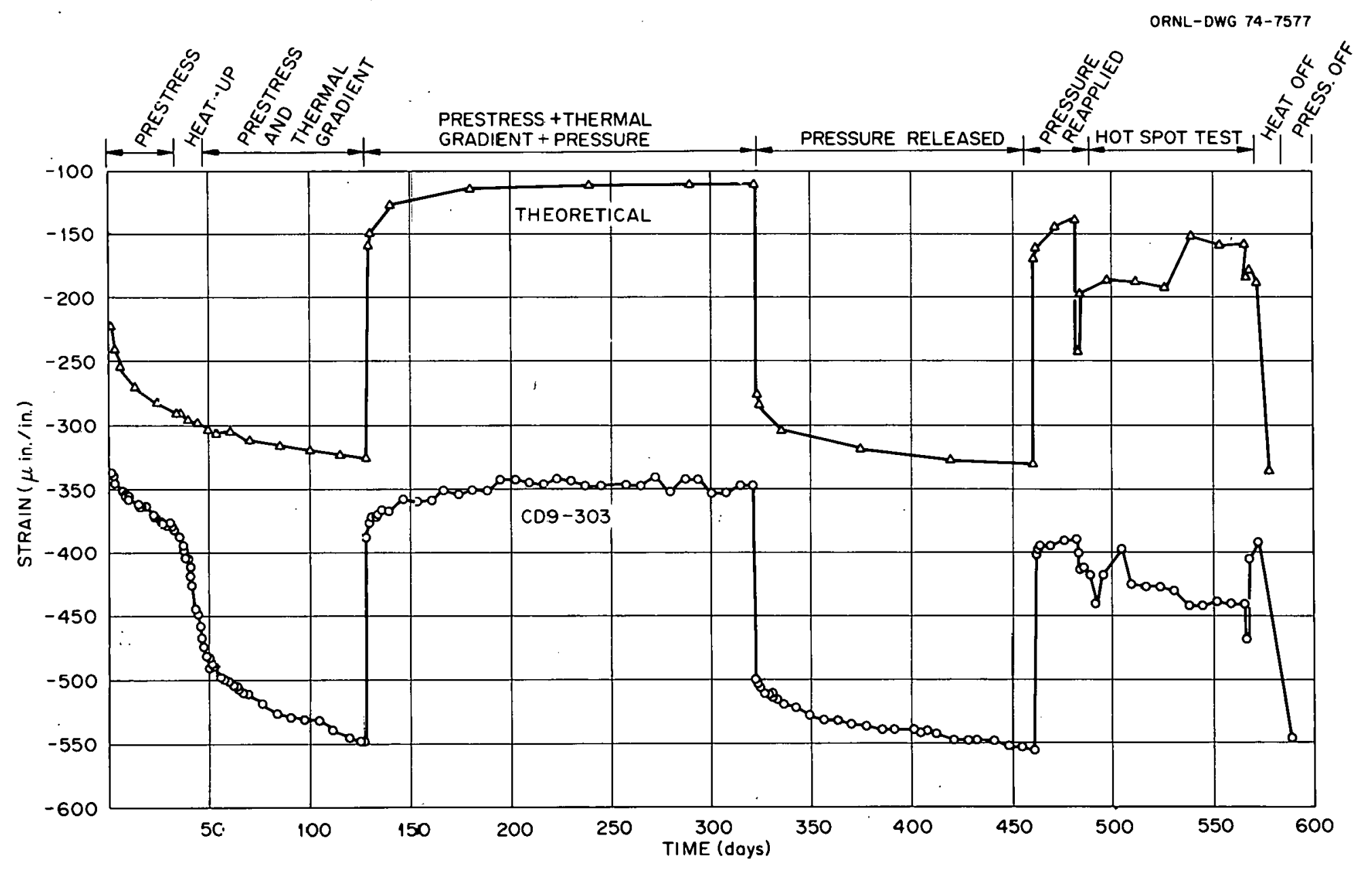

Fig. 6.11. Calculated and experimental results for the third-position circumferential tyfe A vibrating-wire strain gage. 


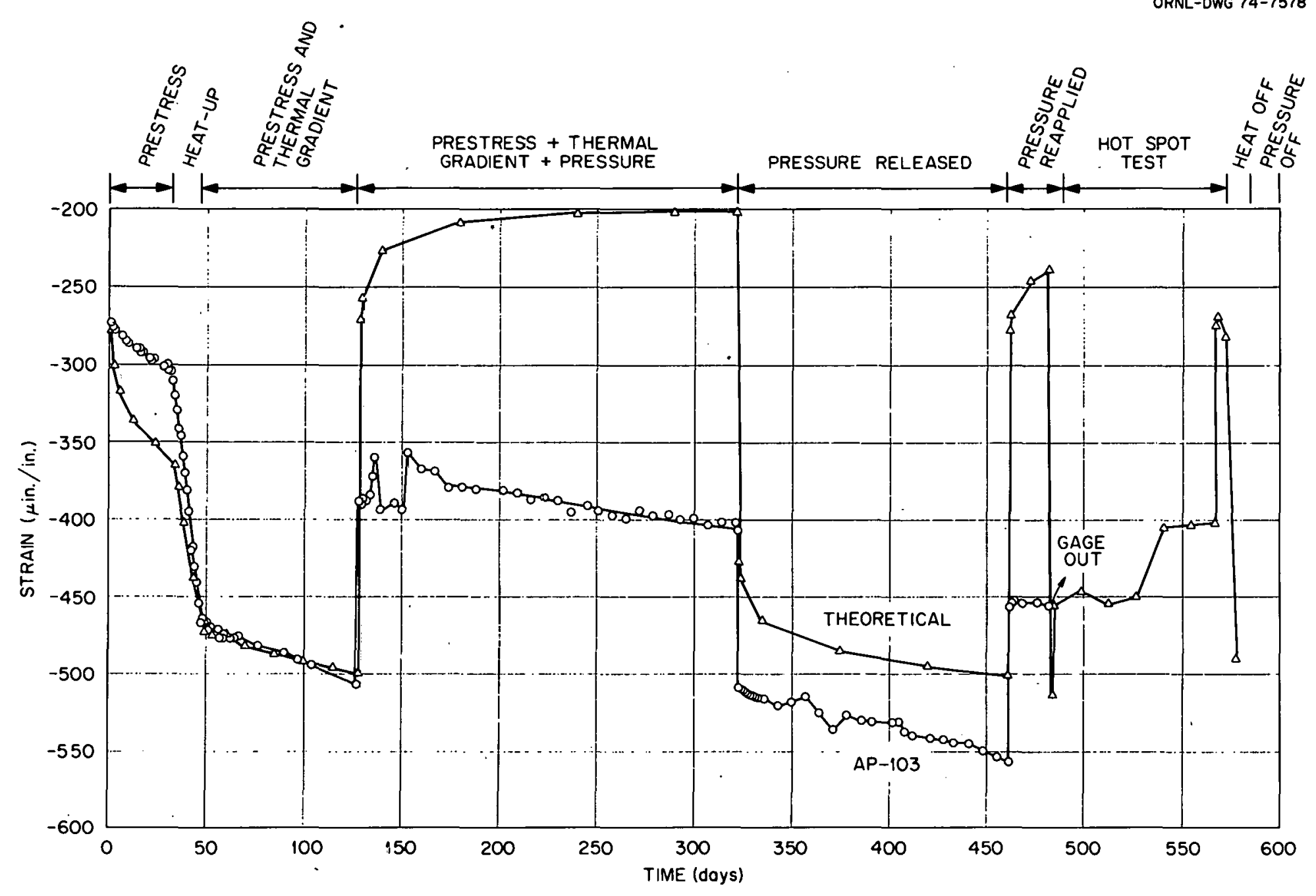

Fig. 6.12. Calculated and experimental results for first-position circumferential type B vibrating-wire strain gage. 


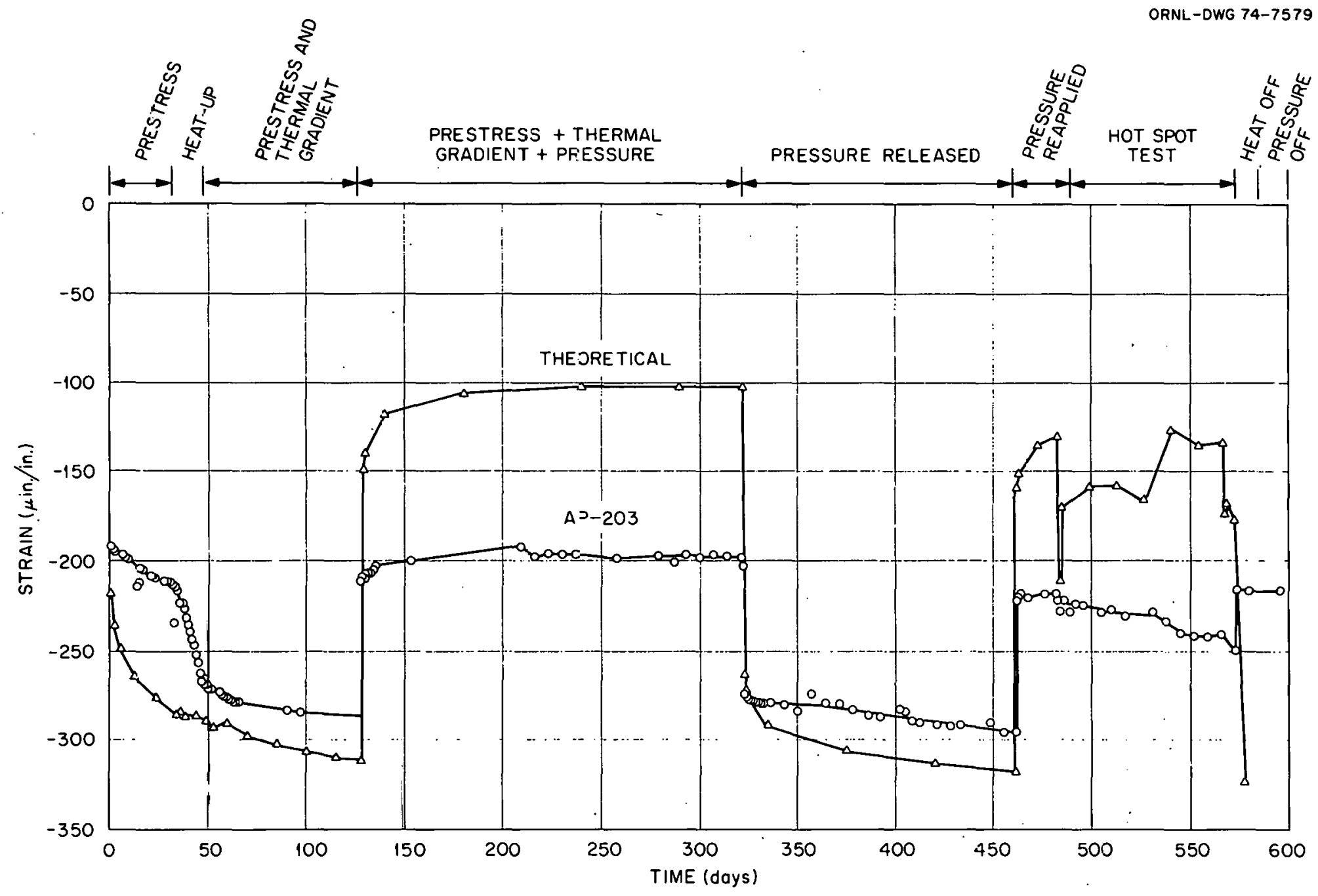

Fig. 6.13. Calculated ard experimental results for second-position circumferential type $B$ vibrating-wire strain gage. 


\subsection{Stress Cel1s}

Experimental and calculated stresses for three circumferentially oriented titanium stress cells are shown in Figs. 6.14 to 6.16 for the first, second, and fourth positions of Fig. 2.1, respectively. These cells functioned satisfactorily until after the initial pressurization loading. Cell 253 performed spasmodically from that point until the pressure was released, and cell 4-11-3 monitored an unexplainable stress drop at 360 days. This test was the first attempt to use a stress cell of

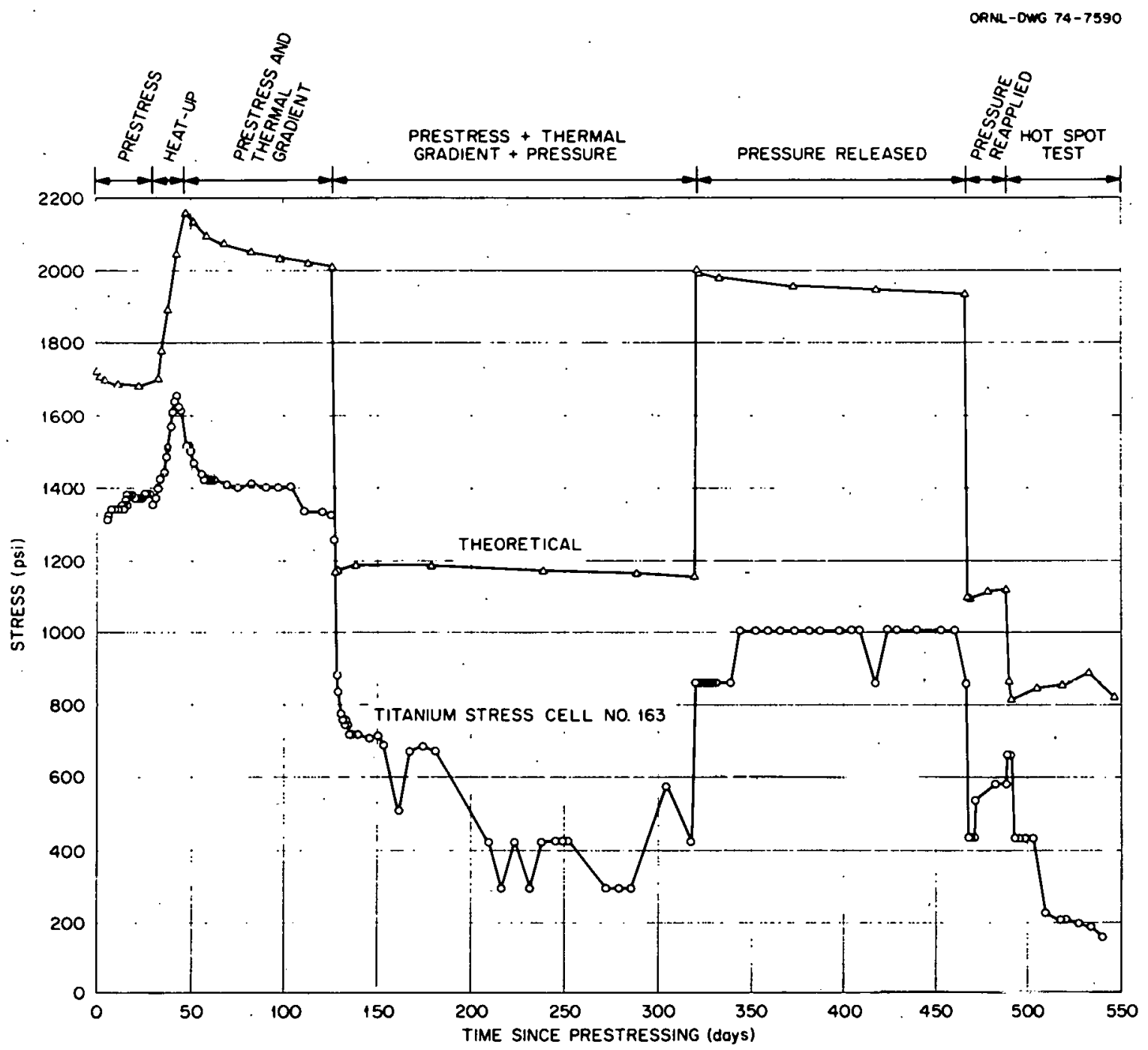

Fig. 6.14. Calculated and experimental results for first-position circumferential titanium stress cell ( 1 psi $=6895 \mathrm{~Pa}$ ). 


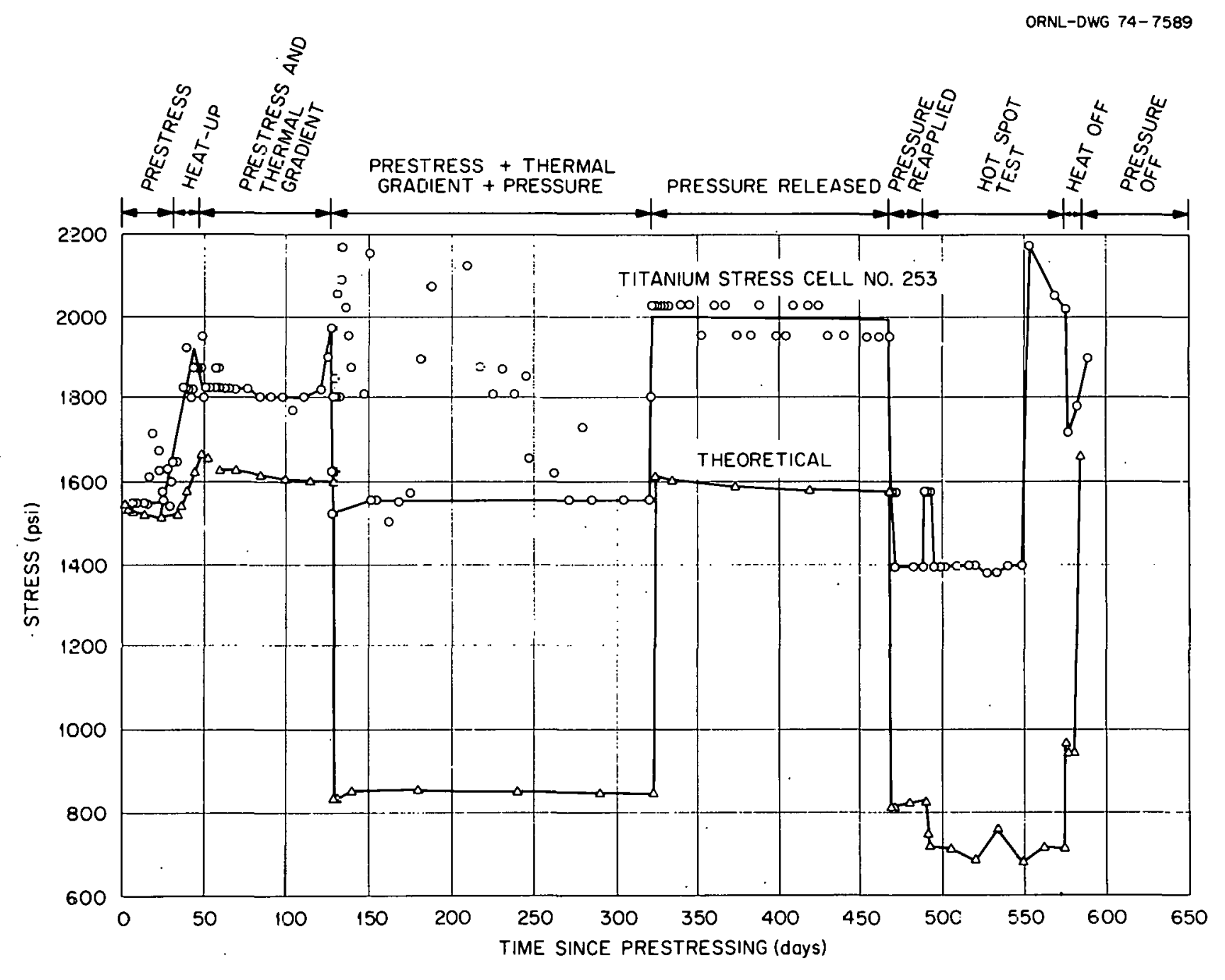

Fig. 6.15. Calculated and experimental results for second-position circumferential titanium stress cell ( 1 psi $=6895 \mathrm{~Pa})$. 


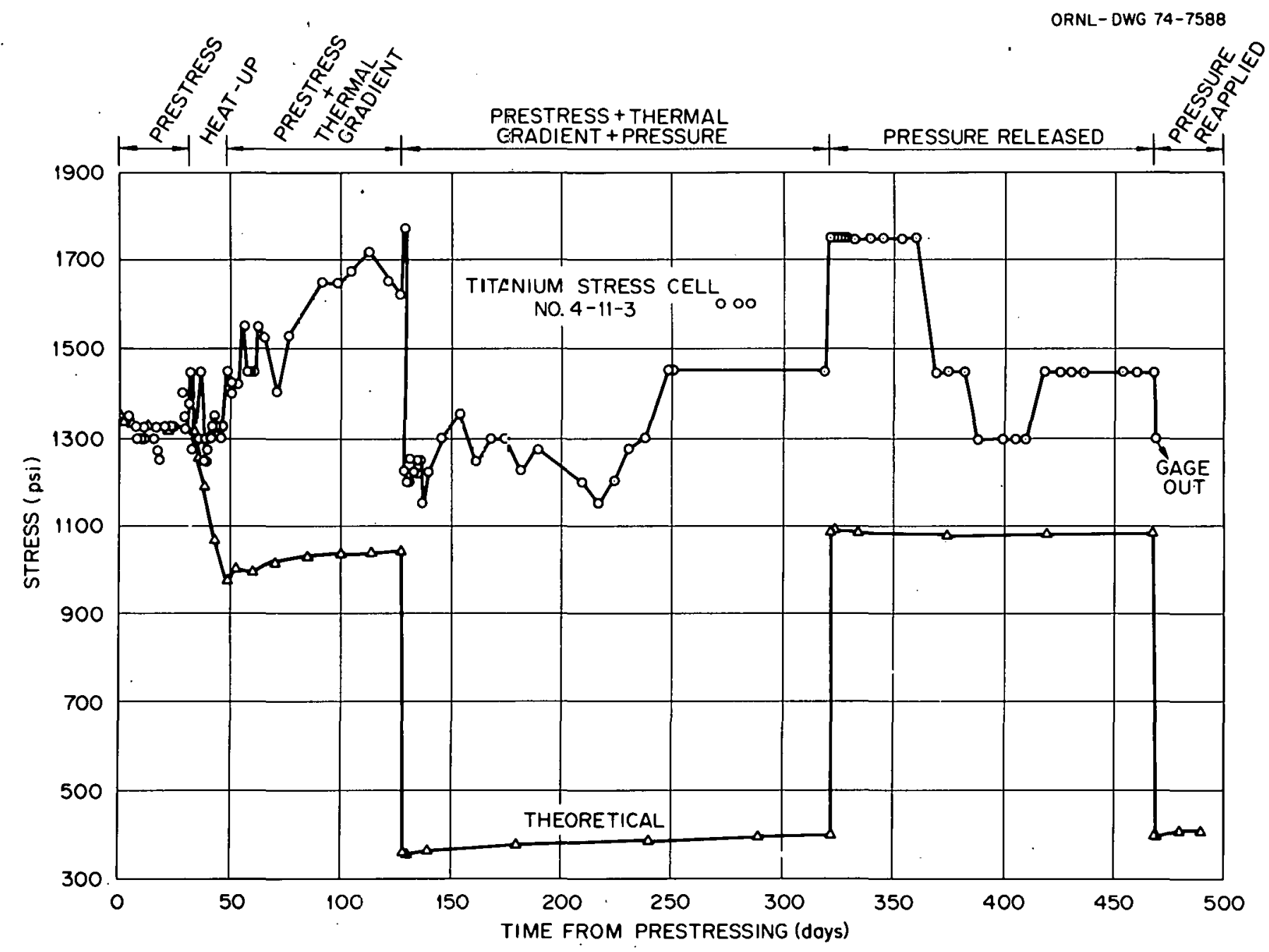

Fig. 6.16. Calculated and experimental results for fourth-position circumferential titanium stress cell $(1 \mathrm{psi}=6895 \mathrm{~Pa})$. 
this particular design; further refinement will be required to ensure reliability and long-term stability.

The pressure diaphragm type of stress cell consists of two singlefilament embedment strain gages positioned in parallel in uniform stress locations, with one having a relatively thin sheet-metal pressure diaphragm attached. The stress is determined by measuring the applied diaphragm pressure required to balance the strain readings of the two gages. A1though this technique appeared capable of measuring stresses developed during short-term loading (see following discussion of companion specimen tests), it was incapable of determining time-dependent stresses in the thermal cylinder model. To do this would require individual diaphragm pressure control and strain gage readout systems.

\subsection{Liner Strain}

The calculated and experimental strains for axial and circumferential weldable strain gages are shown in Figs. 6.17 and 6.18 for the concrete and annulus sides, respectively, of the inside heat exchanger (heat exchanger $B)$. The same general observation made for the embedment instrumentation also applies to these gages; that is, except for the hot-spot test, the strains produced by mechanical loadings were slightly overestimated by the analysis and those produced during heatup were underestimated. The sharp flucuations in calculated results noted previously for the embedment gages during hot-sprit heating were not seen on the liner, but: the greatest disagreement occurred during the hot-spot test. This was especially true in the case of the circumferential gage.

Comparisons for the weldable gages located on the annulus side of the heat exchanger or liner (Fig. 6.18) show considerably greater disagreement. This trend was consistent for all four sets of liner gages. The strains produced by heatup were considerably distorted; however, pressurization strains were consistent with the readings for the concrete side. A final check of the gages on both sides showed that the resistance of the gages on the annulus side, which were not equipped with integral leads, changed during the experiment, whereas the resistance of the gages on the concrete side, which were equipped with integral leads, remained unchanged. It was 


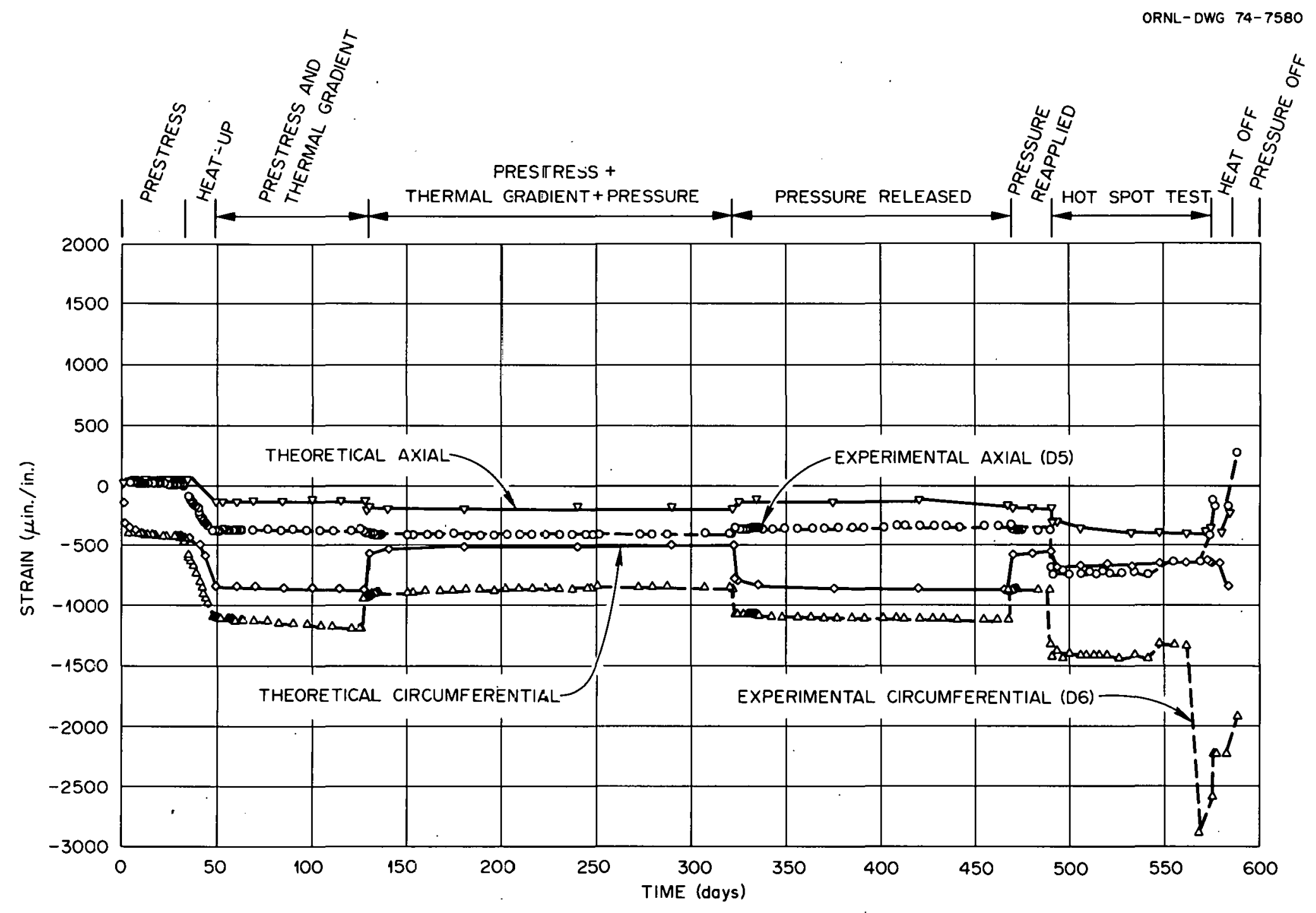

Fig. 6.17. Calculated and experimental results for axial and circumferential weldable strain gages attached to the concrete side of $B$ heat exchanger. 


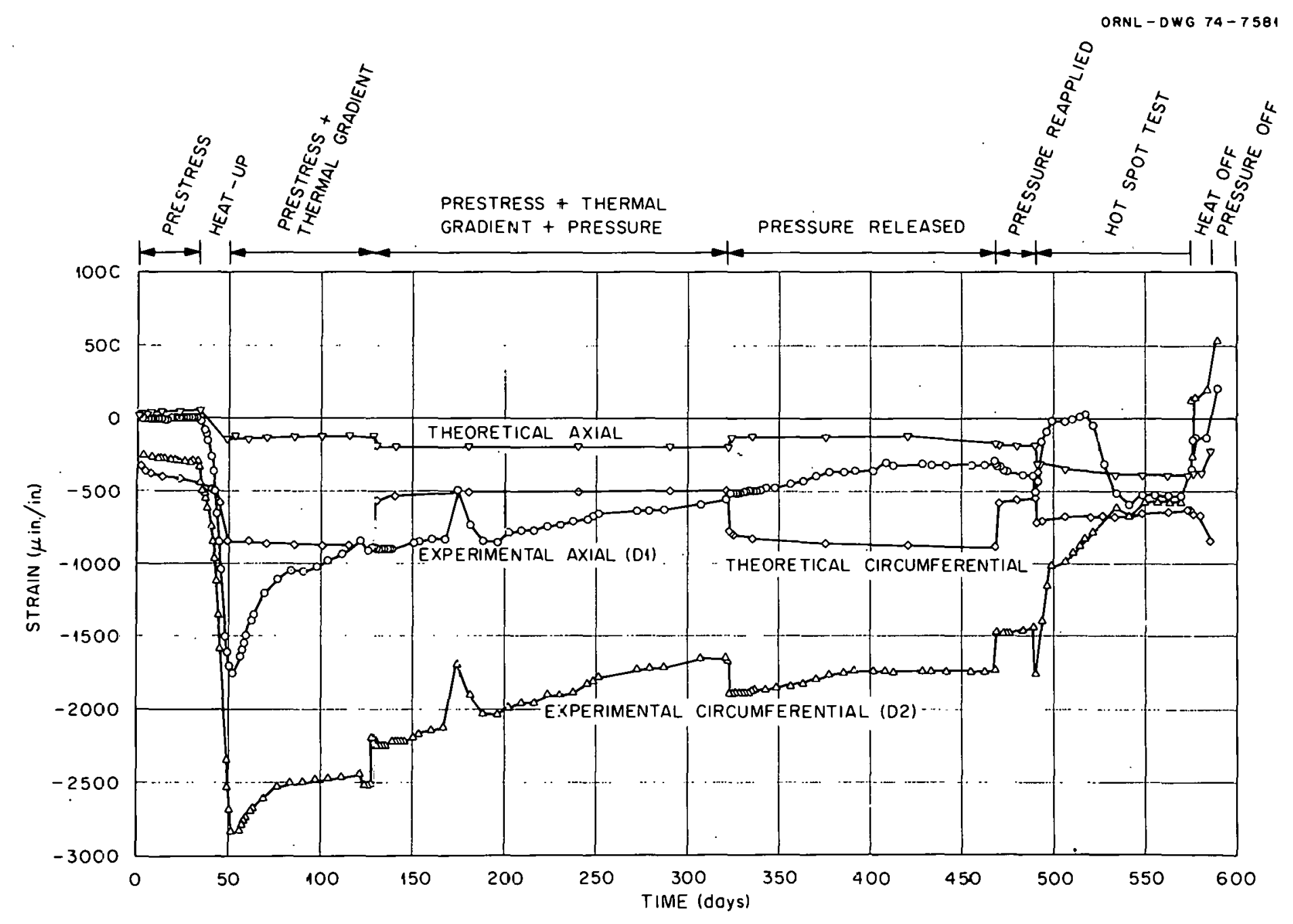

Fig. 6.18. Calculated and experimental results for axial and circumferential weldable strain gages attached to the annulus side of $B$ heat exchanger. 
concluded from this behavior that the gage data shown in Fig. 6.17 represented the behavior of the heat exchanger and that the strain distortions seen in Fig. 6.18 resulted from instrumentation problems rather than from liner behavior.

The results for weldable gages attached at the level of the hot-spot heaters are shown in Fig. 6.19, along with plots for circumferential gages attached to both sides of the heat exchanger for comparison. Although the strains during hot-spot heating were much greater than those shown in Fig. 6.17 , the same general trend is seen; however, in this case, the circumferential gage did not exhibit the previously noted strain jump toward the end of the hot-spot heating period.

\subsection{Tendon Instrumentation}

Individual strands of 12 axial and 8 circumferential prestressing tendons were instrumented with conventional foil-type resistance strain gages, and compression load cells were attached in series with the axial tendons. Results for three axial tendon strain gages are shown in Fig. 6.20. The inner-row tendon gage $\mathrm{CCB}-3$ apparently suffered a bonding failure prior to prestressing and must therefore be discounted. The two outer-row tendon gages, positioned as shown in the small inset of Fig. 6.20, indicated stable conditions until initiation of the hot-spot test. At that time, gage CCB-2 showed a gradual decrease in strain followed by a distinct downward jump. The load-vs-time plot of axial tendon load cell CTR-2 is shown in Fig. 6.21. This transducer, which was attached to the CCB-2 instrumented tendon, indicated a stable loading during the hot-spot heating period. It is therefore doubtful that the strain gage recorded the actual tendon behavior. On the other hand, load transducers CTR-1 and CTR-3, which were coupled to inner-row tendons, measured periodic step-load drops during the experiment. Recent postmortem studies yielded strong evidence that the load changes were produced by progressive corrosion failure of inner-row tendons. The corrosion problem is discussed in Chap. 7.

Strain gage data for two circumferential temdons are shown in Fig. 6.22. In contrast to the axial tendons, the circumferential tendons were located outside the concrete test section and were constrained, as shown in Fig. 


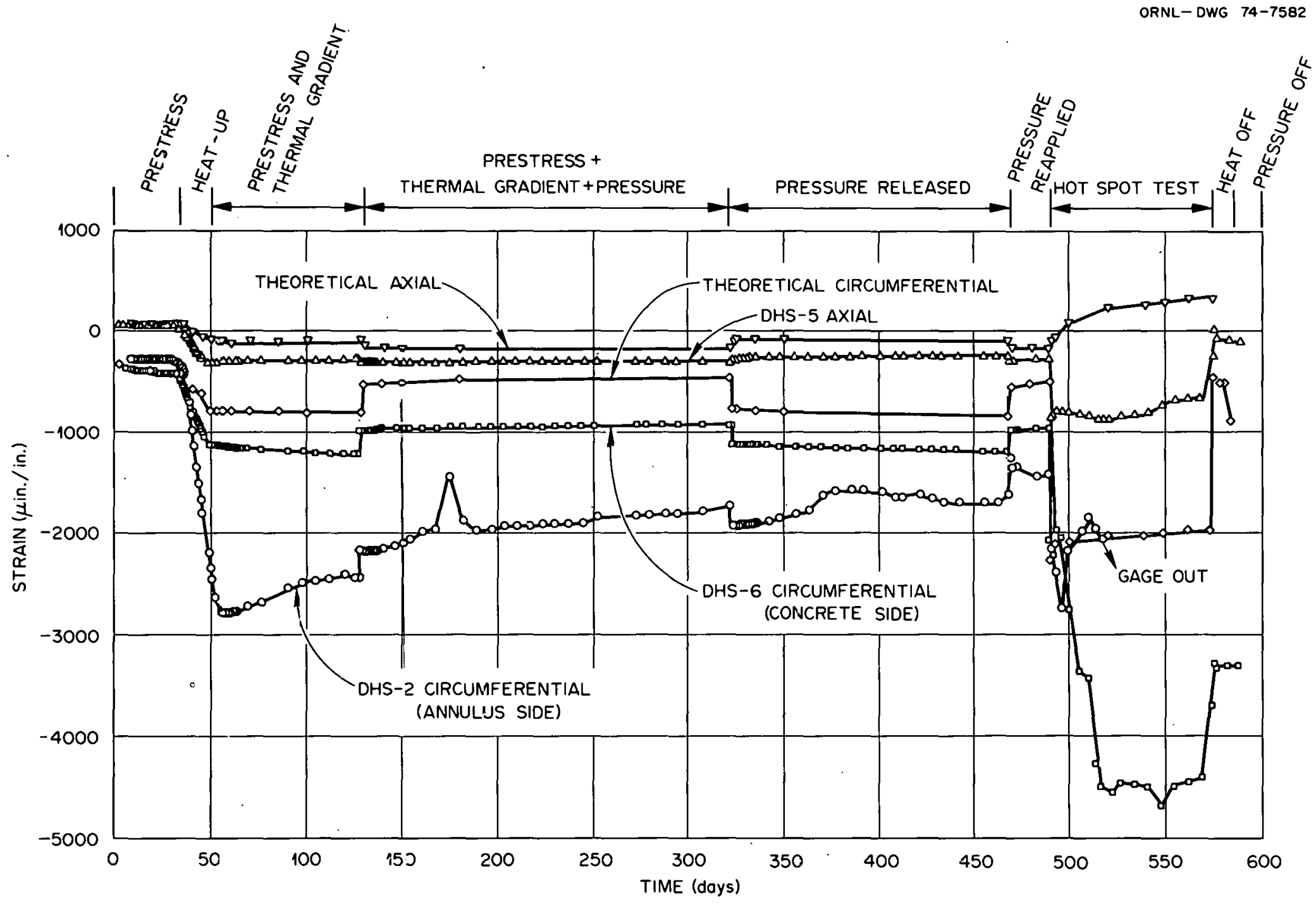

Fig. 6.19. Calculated and experimental results for axial and circumferential weldable strain gages attached to concrete side and for circumferential gage attached to annulus side of $B$ heat exchanger. 


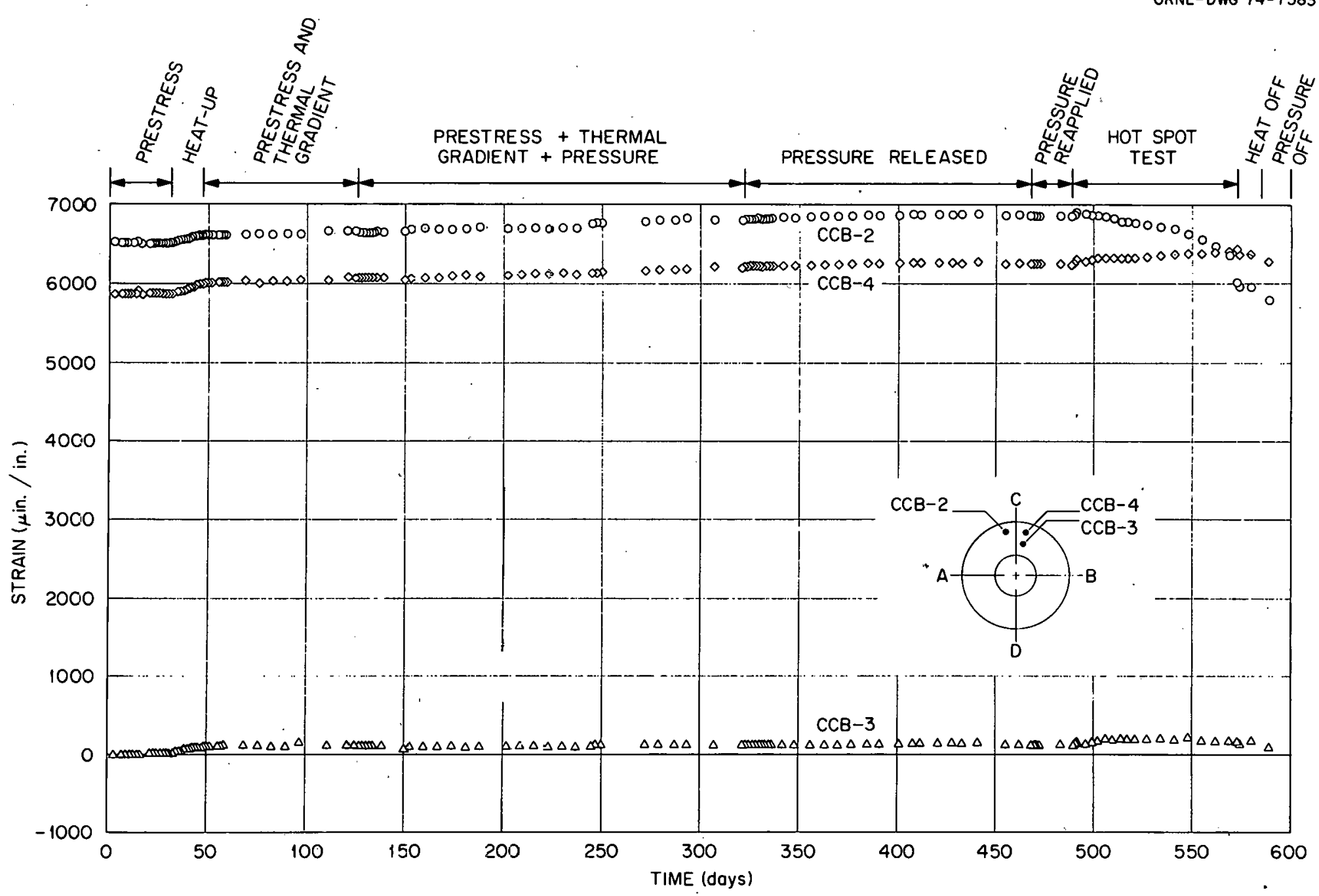

Fig. 6.20. Experimental results for foil-type strain gages attached to axial prestressing tendens. 


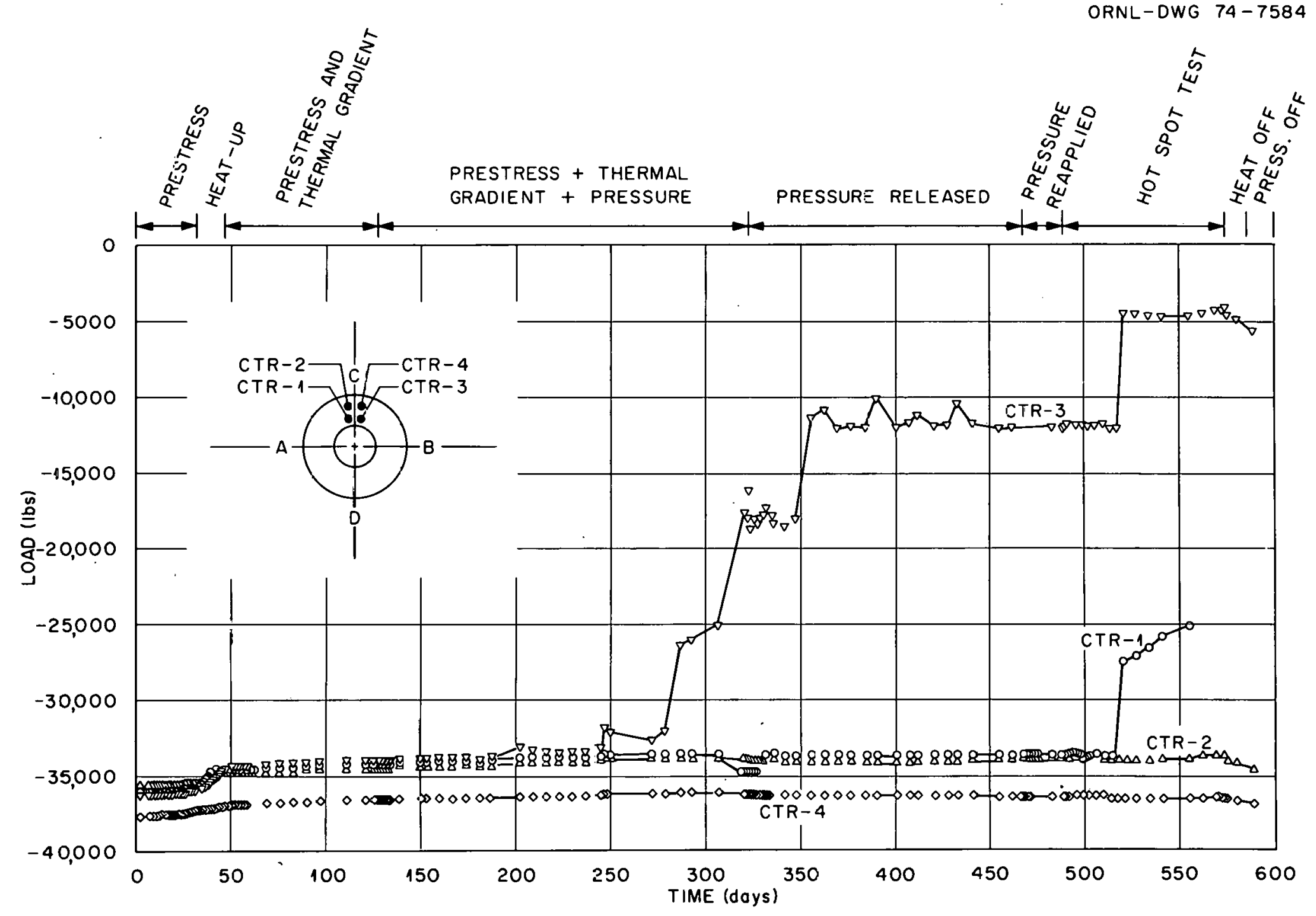

Fig. 6.21. Experimental results for load cells coupled to axial prestressing tendons $(1 \mathrm{lb}=4.448 \mathrm{IJ})$. 


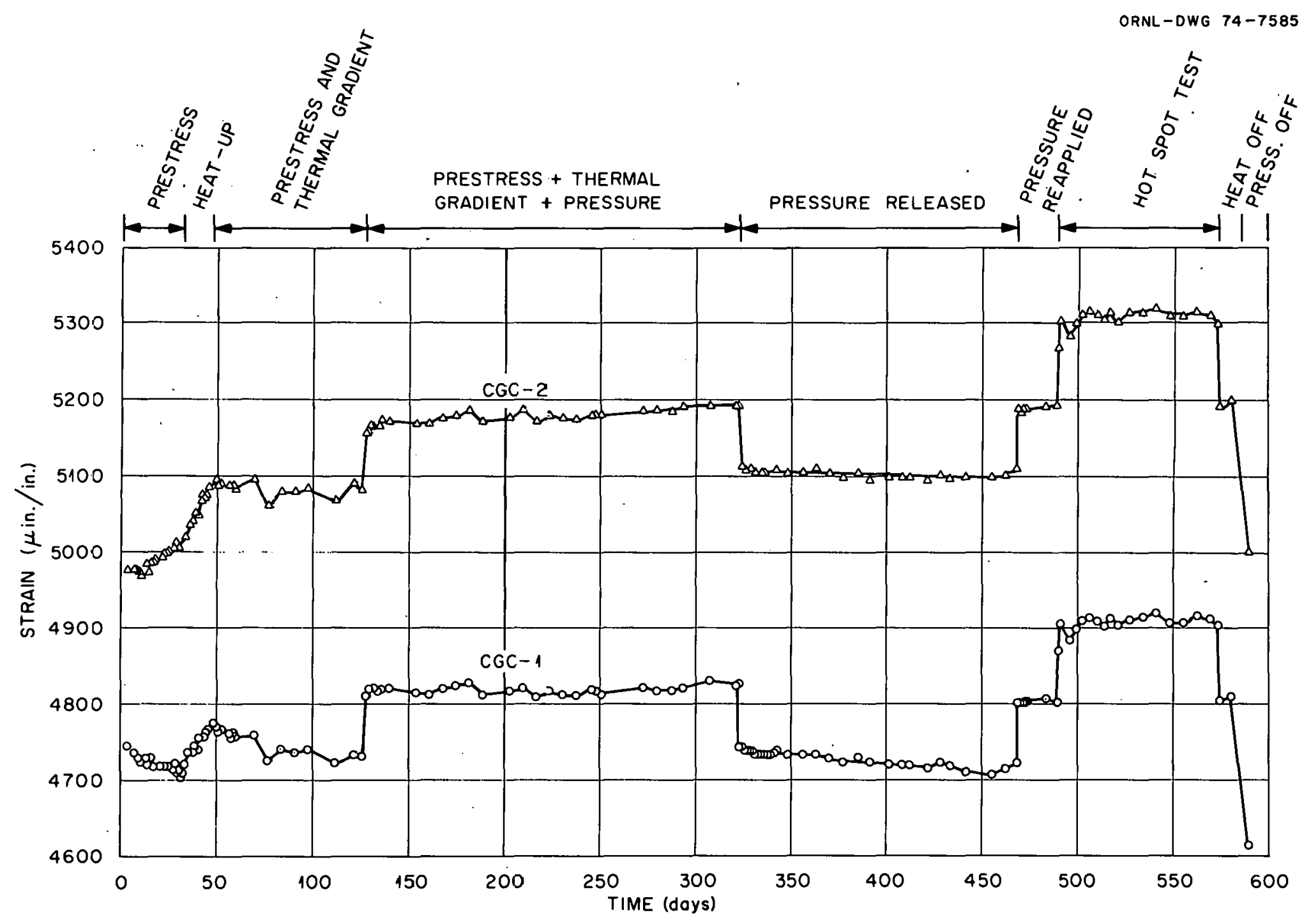

Fig. 6.22. Experimenta1 results for foil-type strain gages attached to circumferential prestressing tendons. 
4.3. Based on the strain gage data, the circumferential tendons apparently performed satisfactorily.

\subsection{Moisture Measurements}

The results of the probe-type neutron and gamma-ray backscattering instrument calibration tests are shown in Fig. 6.23. Inconsistencies were found between the recorded weights and the probe readings of the specimens subjected to $100 \%$ relative humidity when compared with those from the remaining nine specimens; consequently, only two sets of these readings are shown in the figure. No discernible difference was seen between the rates of moisture loss in the remaining three sets; the average values are shown in Fig. 6.23. Of the two curves shown, the upper curve and data points represent total moisture content (based on calculated dry weight), and the lower curve represents evaporable moisture content (based on oven-dried specimen weight). The circled data points on both curves represent the moisture content measured using a $0.3-$ by $0.3-$ by $0.3-\mathrm{m}$ specimen cut from the thermal cylinder model.

This scaling factor was then used to reduce the thermal cylinder moisture probe counts, or readings, to the values shown in Table 6.2. From left to right in the table, the positions extend raidally from near the center of the core (designated as $3.81 \mathrm{~cm}$ ) to the three positions located in the test section. The $69.9-\mathrm{cm}$ position is nearest the $338.7 \mathrm{~K}$ surface and the hot-spot heater; the $77.5-\mathrm{cm}$ position is in the center of the test section; and the $88.9-\mathrm{cm}$ position is located nearest to the $297 \mathrm{~K}$ surface, which is the outer surface of the section. In most cases, each value listed in the table represents the average of nine 1-min counts, which are taken in sets of three at each of three levels in the cylinder.

Initially, little variation is seen in the readings for the various radial positions in the cylinder, which indicates that the moisture seal was effective and little migration of moisture resulted from the heating. The intensive heating during the hot-spot test resulted in excessively high counts at 614 days. Only those readings that appeared to be relatively unaffected by the heating are shown in Table 6.2; however, the high reading shown for the center of the core was caused by heating of the moisture probe. 


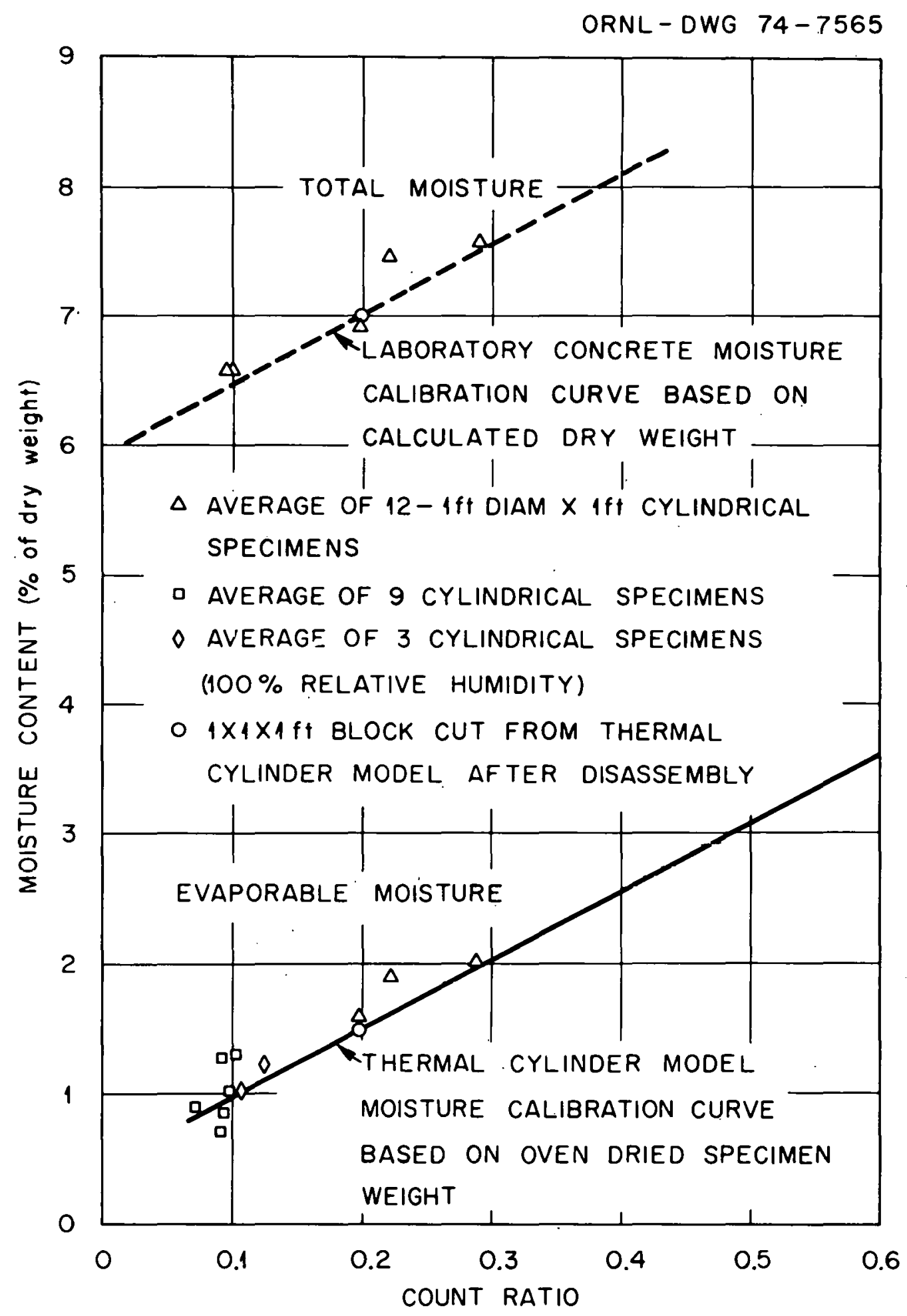

Fig. 6.23. Total and evaporable moisture-content calibration curves for ORNL thermal cylinder concrete having $7.59 \%$ as-cast total moisture content $(1 \mathrm{ft}=0.3048 \mathrm{~m})$. 
Table 6.2. Average evaporable moisture content (\% of oven-dried weight) for various radial positions in ORNL thermal cylinder model

\begin{tabular}{|c|c|c|c|c|c|c|c|}
\hline \multirow{3}{*}{$\begin{array}{l}\text { Days since } \\
\text { prestressing }\end{array}$} & \multicolumn{6}{|c|}{ Radial distance from center $[\mathrm{cm}$ (in.)] } & \multirow{3}{*}{ Status of test section } \\
\hline & \multicolumn{3}{|c|}{ 1.05-m-diam (41.5 in.) core } & \multicolumn{3}{|c|}{$\begin{array}{c}2.06-\mathrm{m}-\mathrm{OD}(81-\mathrm{in} .) \text { test section } \\
{[0.46 \mathrm{~m}(18 \mathrm{in.}) \text { thick }]}\end{array}$} & \\
\hline & $3.8(1.5)$ & $20.3(8.0)$ & $29.4(15.5)$ & $69.9(27.5)$ & $77.5(30.5)$ & $88.9(35)$ & \\
\hline 130 & & 1.47 & 1.44 & 1.41 & 1.40 & 1.37 & $297 \mathrm{~K}\left(75^{\circ} \mathrm{F}\right)$ inside, $297 \mathrm{~K}\left(75^{\circ} \mathrm{F}\right)$ outside \\
\hline 135 & 1.48 & 1.53 & 1.46 & 1.45 & 1.46 & 1.44 & $314 \mathrm{~K}\left(105^{\circ} \mathrm{F}\right)$ inside, $297 \mathrm{~K}\left(75^{\circ} \mathrm{F}\right)$ outside \\
\hline 146 & 1.49 & 1.53 & 1.46 & 1.47 & 1.46 & 1.45 & $339 \mathrm{~K}\left(150^{\circ} \mathrm{F}\right)$ inside, $297 \mathrm{~K}\left(75^{\circ} \mathrm{F}\right)$ outside \\
\hline 175 & 1.51 & 1.55 & 1.48 & 1.47 & 1.49 & 1.47 & $339 \mathrm{~K}\left(150^{\circ} \mathrm{F}\right)$ inside, $297 \mathrm{~K}\left(75^{\circ} \mathrm{F}\right)$ outside \\
\hline 223 & 1.51 & 1.55 & 1.47 & 1.46 & 1.48 & 1.47 & $\begin{array}{l}339 \mathrm{~K}\left(150^{\circ} \mathrm{F}\right) \text { inside, } 297 \mathrm{~K}\left(75^{\circ} \mathrm{F}\right) \text { outside, } \\
\text { before pressurization }\end{array}$ \\
\hline 236 & 1.47 & 1.51 & 1.46 & 1.44 & 1.46 & 1.45 & $\begin{array}{l}339 \mathrm{~K}\left(150^{\circ} \mathrm{F}\right) \text { inside, } 297 \mathrm{~K}\left(75^{\circ} \mathrm{F}\right) \text { outside, } \\
\text { pressurized to } 4.83 \mathrm{MPa}(700 \mathrm{psi})\end{array}$ \\
\hline 318 & 1.51 & 1.54 & 1.47 & 1.47 & 1.48 & 1.47 & Same as for 236 days \\
\hline 403 & 1.54 & 1.57 & 1.52 & .1 .44 & 1.46 & 1.44 & Same $3 s$ for 236 days \\
\hline 425 & 1.54 & 1.58 & 1.53 & 1.44 & 1.45 & 1.43 & $\begin{array}{l}339 \mathrm{~K}\left(150^{\circ} \mathrm{F}\right) \text { inside, } 297 \mathrm{~K}\left(75^{\circ} \mathrm{F}\right) \text { outside, } \\
\text { pressure released }\end{array}$ \\
\hline 614 & $a$ & $a$ & $c:$ & $1.65^{6}$ & 1.52 & 1.48 & $\begin{array}{l}\text { Repressurized to } 4.83 \mathrm{MPa}(700 \mathrm{psi}) \text { and } \\
\text { subjected to } 505 \mathrm{~K}\left(450^{\circ} \mathrm{F}\right) \text { hot-spot } \\
\text { heating }\end{array}$ \\
\hline 686 & 1.20 & 1.31 & 1.20 & 1.46 & 1.50 & 1.50 & $\begin{array}{l}\text { After cooldown to } 339 \mathrm{~K}\left(150^{\circ} \mathrm{F}\right) \text { inside, } \\
297 \mathrm{~K}\left(75^{\circ} \mathrm{F}\right) \text { outside, at pressure }\end{array}$ \\
\hline 718 & 1.23 & 1.29 & 1.19 & 1.43 & 1.48 & 1.48 & $\begin{array}{l}\text { After complete cooldown to } 297 \mathrm{~K}\left(75^{\circ} \mathrm{F}\right) \\
\text { inside, } 297 \mathrm{~K}\left(75^{\circ} \mathrm{F}\right) \text { outside, and } \\
\text { pressure released }\end{array}$ \\
\hline
\end{tabular}

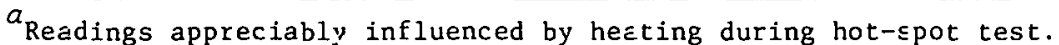


Since the moisture probe was found to be temperature sensitive, the increases in values coinciding with temperature changes to which the model was subjected are the result of the temperature increases. If these temperature effects are taken into consideration, it can be concluded that the copper-epoxy moisture seal was adequate for conditions simulating normal PCRV operation. An examination of the moisture readings made in the core region after the hot-spot test shows that a small amount of moisture was lost during heating. This is a reasonable conclusion based on the measured temperature profiles, which show that a large portion of the core was subjected to temperatures of 352.6 to $366.5 \mathrm{~K}$.

A similar examination of probe readings for the model test section indicates that moisture content remained constant during and after the hotspot test. It should be noted that a relatively small portion of this test section was subjected to elevated temperatures during the hot-spot heating; in fact, a fairly large portion of the section was cooled to temperatures of $311 \mathrm{~K}$ or lower, which should account for the differences of moisture content in the core and test ring. There is also little evidence of appreciable migration of moisture from inside to outside of the test section during the course of the experiment except for the readings made after the hot-spot heating, which show a slight increase in moisture in the two outer probe positions in comparison with the innermost position.

Although it is difficult to make any meaningful comparison between the moisture content of the model and that of the relatively small moisture calibration specimens, values can be used to provide an order-of-magnitude evaluation. At 28 days, the average moisture content of the specimens at $100 \%$ relative humidity was $1.89 \%$, while the average moisture content of the specimens subjected to the three lower relative humidities was $1.30 \%$. In comparison, the moisture content for the thermal cylinder model at 227 days (130 days after prestressing) was $1.42 \%$.

\subsection{Companion Specimen Tests}

Two $0.46-$ by $1.02-\mathrm{m}$ concrete cylinders were instrumented with every type of embedment stress and strain measuring device employed in the thermal cylinder in order to provide a better understanding of basic gage 
behavior. These companion test cylinders were cast, sealed, and heated, and one was loaded uniaxially in accordance with the time schedule of the large model. Both cylinders were maintained at a temperature of $338.7 \mathrm{~K}$ during the time-dependent portion of the study. Cylinder M-1 was subjected to a 24.8-MPa uniaxial loading 56 days from the time of thermal cylinder model prestressing, and cylinder $M-2$ remained unstressed during the model testing period. The unabridged strain history of the companion specimen single-filament resistance strain gages is shown in Fig. 6.24. The axial gages in both cylinders experienced excessive drift quite early in the experiment, and the unstressed M-2 cylinder lateral gage began drifting severcly at 420 days. On the other hand, the stressed M-1 specimen lateral gage performed consistently for the duration of the experiment. The excessive number of gage failures was probably caused by the relatively high temperatures to which these gages were subjected.

In addition to the sustalned testing period, the M-1 specimen was loaded and unloaded in steps both at 297 and $338.7 \mathrm{~K}$; the M-2 specimen was also load tested for short time periods at $297 \mathrm{~K}$ to provide additional gage data. Typical stress-vs-strain plots for these short-term tests are shown in Figs. 6.25 and 6.26 for axial single-filament resistance gage M1-SEB-111 and type B vibrating-wire gage M2-P-101, respectively. The concrete properties obtained for the operating gages of each type are shown in Table 6.3, where the final values are average 180-day strength test results for moist-cured 15.2 - by $30.5-\mathrm{cm}$ cylinders. Since the much larger companion specimens were sealed to prevent moisture loss and were at least 180 days of age, the 180-day compressive strength test data were used as the basis for comparison of gage performance. The $338.7 \mathrm{~K}$ data were obtained after approximately 550 days of heating; consequently, the modulus of elasticity should be slightly higher than the 180-day value. All the gages could not be evaluated because of premature failure nf some of the companion specimen gages; however, certain conclusions can be drawn baecd on the available data.

The single-filament resistance and type B vibrating-wire embedment gages gave the most accurate readings. The wound-wire resistance gages also performed satisfactorily at both temperatures, which was surprising since the thermal cylinder model gages of this type were unsatisfactory. 


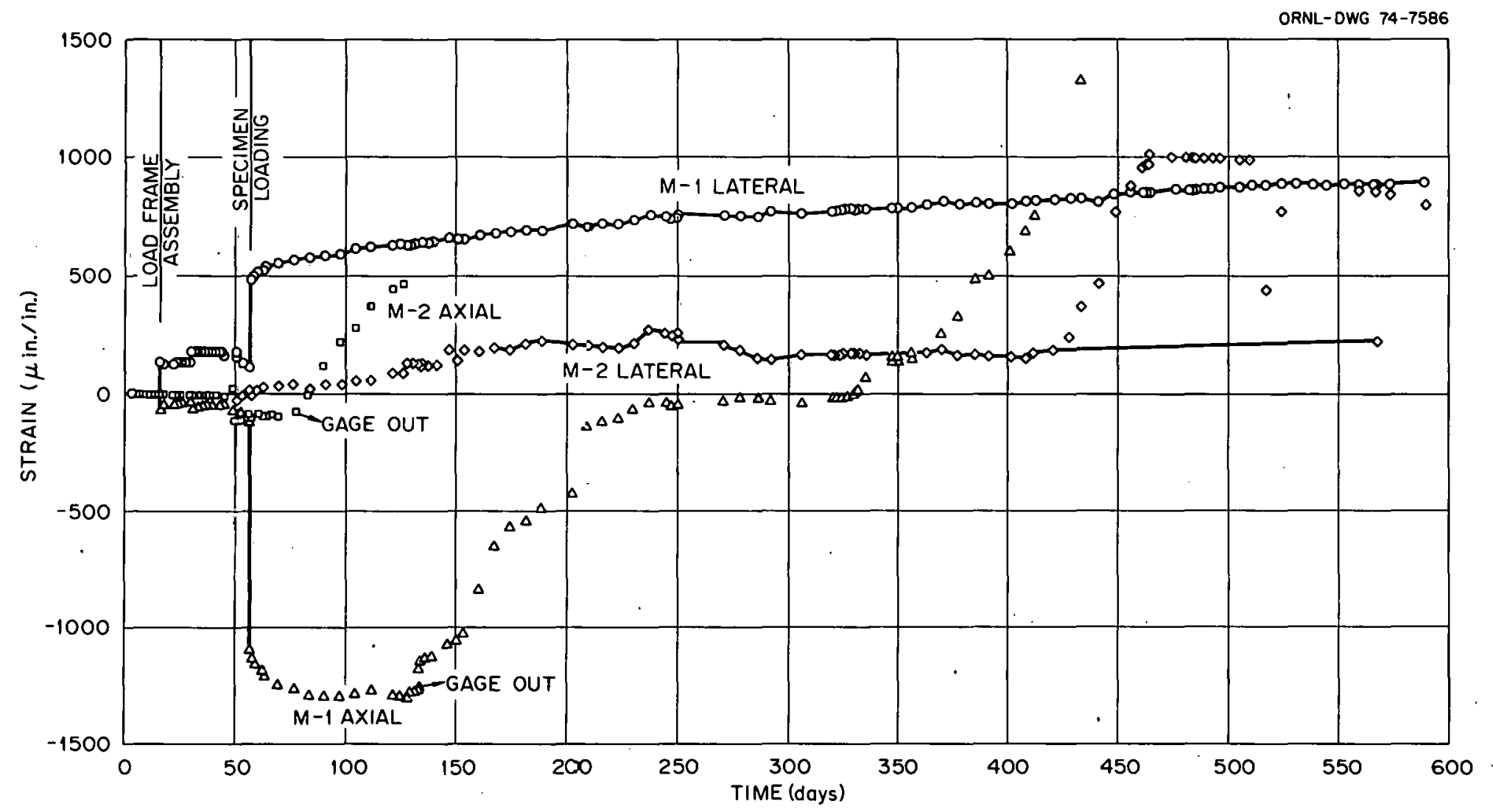

Fig. 6.24. Experinental results for axial and lateral singlefilament resistance strain gages of stressed $\mathrm{M}-1$ and unstressed $\mathrm{M}-2$ companion concrete cylinders. 


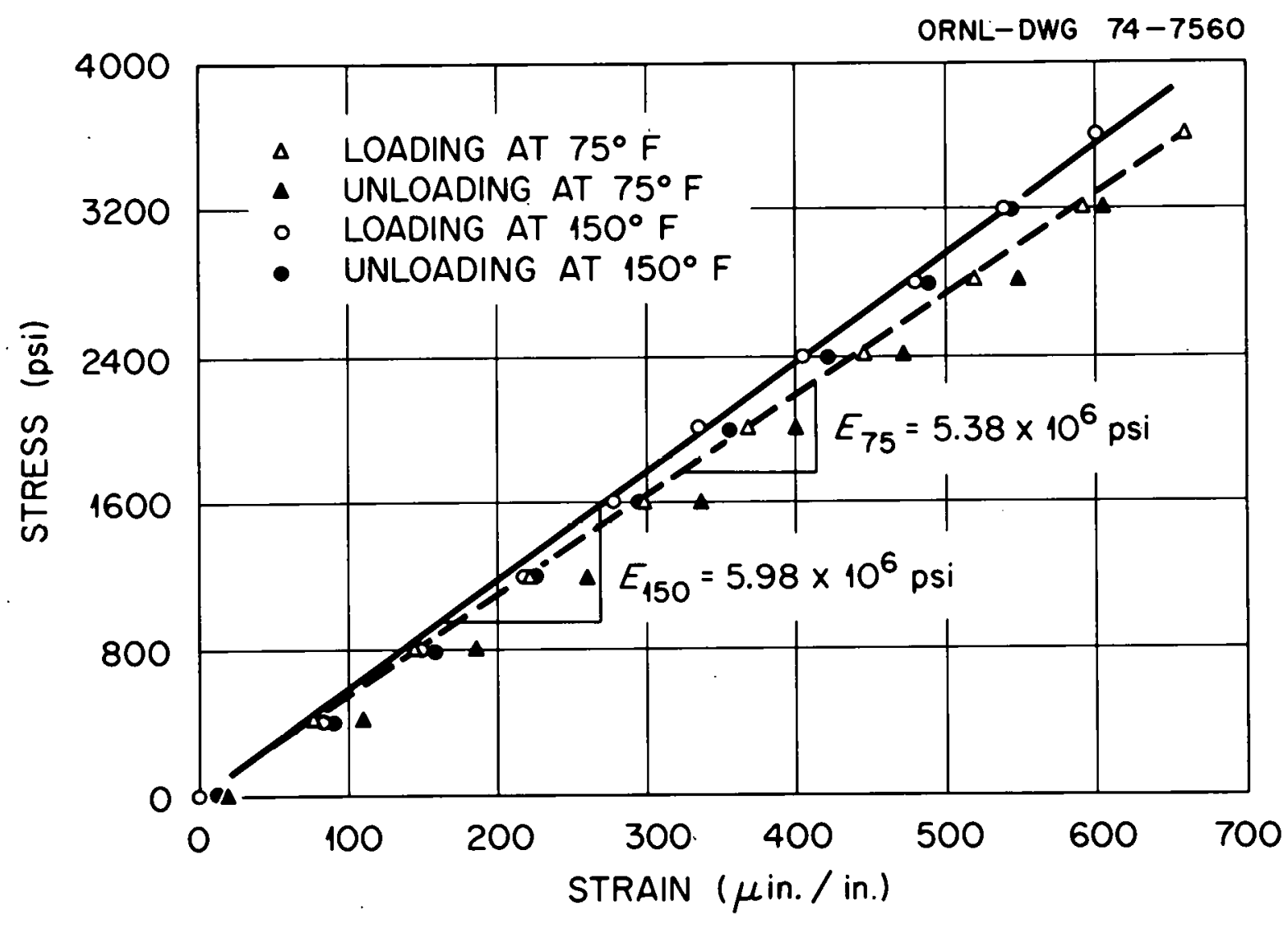

Fig. 6.25. Results of short-time M-1 specimen load test for axial single-filament resistance strain gage $[1$ psi $=6895 \mathrm{~Pa} ; \mathrm{K}=273.15+5 / 9$ $\left.\left({ }^{n} \mathrm{~F}-32\right)\right]$.

The type $\mathrm{C}$ vibrating-wire gage gave reasonable results at room temperature, but the $338.7 \mathrm{~K}$ readings for this gage were significantly low.

The surface resistance gages listed in Table 6.3 were experimental gages developed as part of the ORNL biaxial creep test apparatus. ${ }^{8}$ Three gages were attached to pairs of small steel posts protruding from the surface of each cylinder at equal angular spacing. Although these gages were not operational during the room-temperature test, they performed satisfactorily at $338.7 \mathrm{~K}$.

The results of the uniaxial compression testing of the titanium stress cell are shown in Fig. 6.27. In addition to the companion specimen tests of the embedded gages, each stress cell was load-calibrated under uniaxial compression. The results indicated that the embedded stress cell readings must be multiplied by 1.19 to obtain the actual stress in the concrete. 


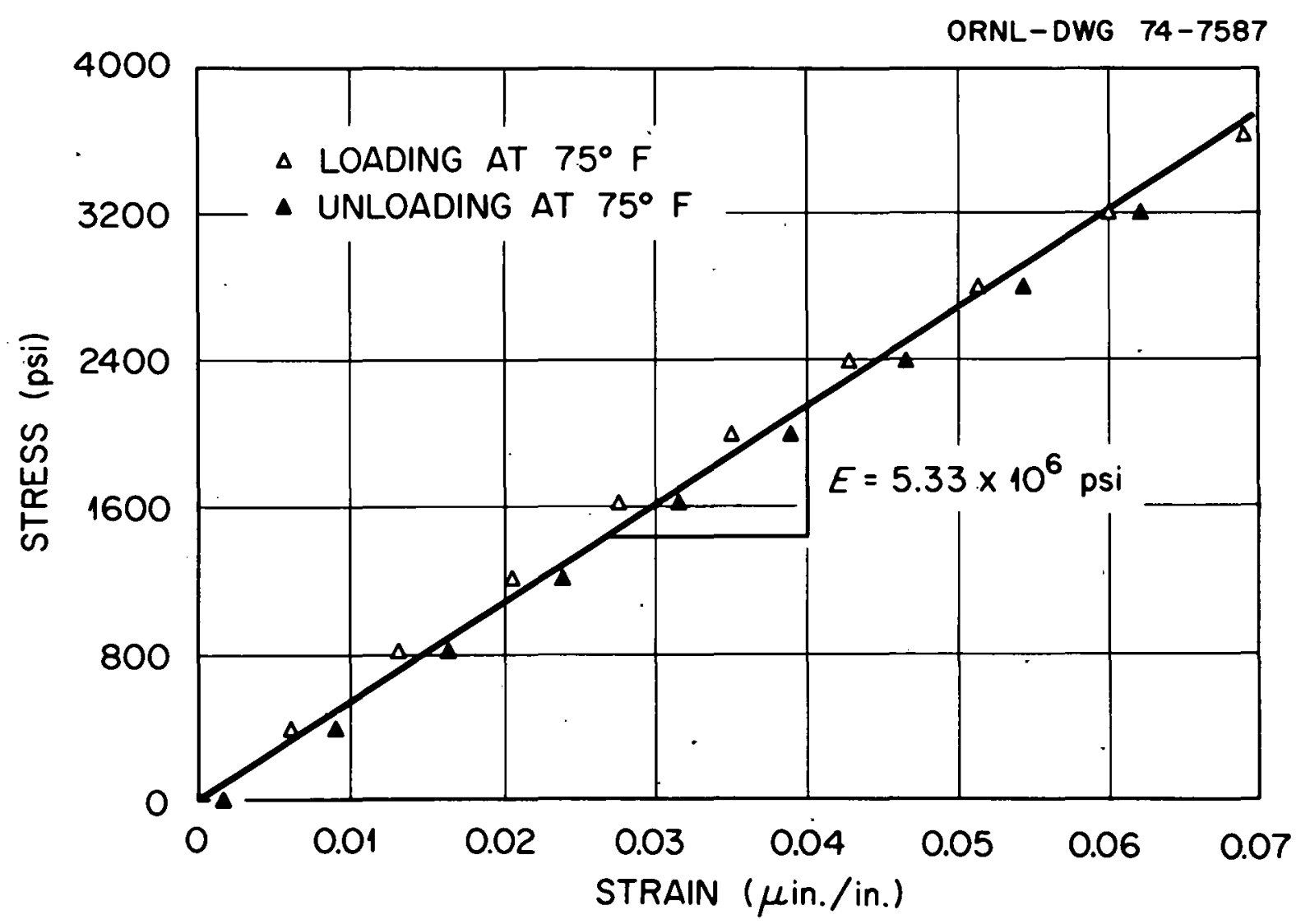

Fig. 6.26. Results of short-time M-2 specimen load test for axial type $B$ vibrating-wire strain gage $[1$ psi $=6895 \mathrm{~Pa} ; \mathrm{K}=273.15+5 / 9$ $\left.\left({ }^{\circ} \mathrm{F}-32\right)\right]$.

We also attempted to monitor the embedded pressure stress cells during the companion specimen tests, but owing to a need for additional and more sophisticated instrumentation, we were able to obtain only the following three readings:

\begin{tabular}{c}
$\begin{array}{c}\text { Actual stress } \\
{[\mathrm{MPa} \text { (psi)] }}\end{array}$ \\
\hline $2.77(402)$ \\
$5.48(795)$ \\
$25.28(3666)$
\end{tabular}

\begin{tabular}{c}
$\begin{array}{c}\text { Stress cell pressure } \\
{[\mathrm{MPa} \text { (psi)] }}\end{array}$ \\
\hline $4.83(700)$ \\
$10.34(1500)$ \\
$28.96(4200)$
\end{tabular}

\begin{tabular}{c}
$\begin{array}{c}\text { Percent } \\
\text { deviation }\end{array}$ \\
\hline 74 \\
89 \\
15
\end{tabular}

The pressure stress cell was able to determine the maximum specimen stress to within $15 \%$, but was unable to measure the lower stress levels to a reasonable accuracy. 
Table 6.3. Companion specimen compression test results

\begin{tabular}{|c|c|c|c|}
\hline \multirow{2}{*}{ Gage type } & $\begin{array}{r}\text { Modulus of } \\
{[\mathrm{GPa} \text { (1 }}\end{array}$ & $\begin{array}{l}\text { lasticity } \\
\text { psi)] }\end{array}$ & \multirow{2}{*}{$\begin{array}{c}\text { Poisson's } \\
\text { ratio }\end{array}$} \\
\hline & $297 \mathrm{~K}\left(75^{\circ} \mathrm{F}\right)$ & $339 \mathrm{~K}\left(150^{\circ} \mathrm{F}\right)$ & \\
\hline
\end{tabular}

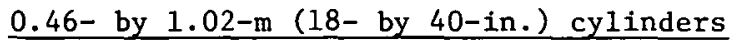

\begin{tabular}{|c|c|c|c|}
\hline Single-filament resistance & $37.09(5.38)$ & $41.23(5.98)$ & \\
\hline Type B vibrating-wire & $36.75(5.33)$ & & 0.24 \\
\hline Type C vibrating-wire & $32.20(4.67)$ & $32.68(4.74)$ & \\
\hline Wound-wire resistance & $33.78(4.90)$ & $44.13(6.40)$ & 0.31 \\
\hline Surface resistance & & $40.00(5.80)$ & \\
\hline
\end{tabular}

$15.2-$ by $30.5-\mathrm{cm}$ (6- by 12-in.) concrete strength cylinders

\begin{tabular}{lll} 
Surface resistance $^{a}$ & $37.23(5.40)$ & 0.28 \\
\hline
\end{tabular}

$a_{\text {See Table }} 4.1$ for additional concrete strength data.

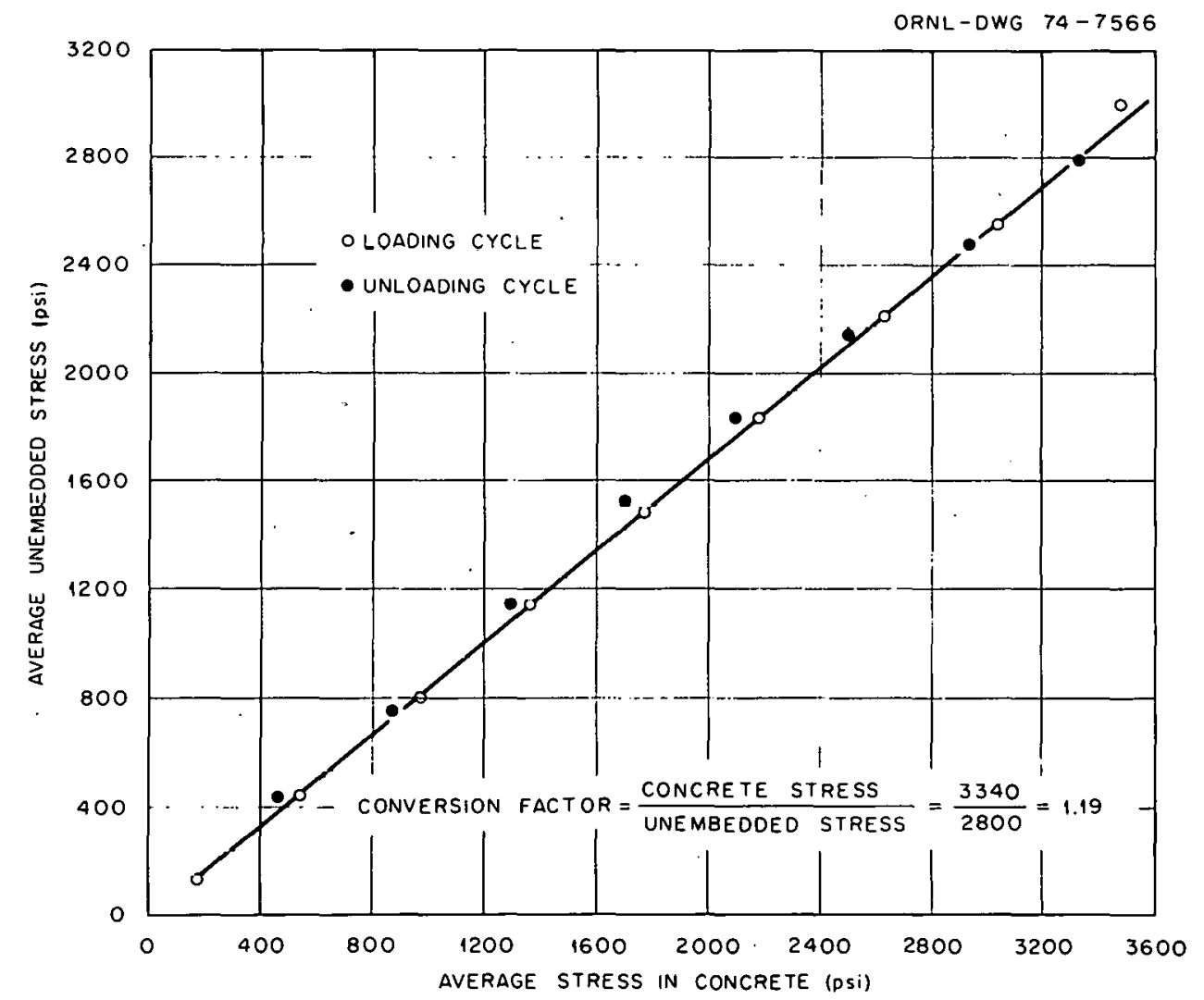

Fig. 6.27. Comparison of laboratory calibration of concrete embedment stress rel1 for embedded and unembedded conditions ( 1 psi $=6895 \mathrm{~Pa})$. 
Although both types of stress-measurement devices used in this experiment offer some promise, considerable work will be required to develop a satisfactory embedment stress cell that is capable of monitoring timedependent stresses in prestressed concrete structures. 


\section{POSTMORTEM STUDIES}

\subsection{Disassembly of the Model}

Detensioning of the thermal cylinder model was completed on May 30 , 1973 - 771 days from the time of the original tensioning of the prestressing system. First the circumferential tendons were completely detensioned; then the axial tendons were detensioned one step at a time (in sets of 13 in a quadrant), using the reverse of the original loading sequence.

One significant system failure was revealed during the detensioning operation. The axial tendons shown in Fig. 7.1 were equally divided into an inner and an outer row on the model test section. The hydraulic pull rams, which are shown positioned on top of the model in Fig. 4.3, were coupled to the tendons, and the loading was raised to 200 to $209 \mathrm{kN}$ to lift off, or unseat, the restraining nut, which was then loosened. The first inner-row tendon was pulled out excessively at $290 \mathrm{kN}$, thereby indicating failure. All the outer-row tendons required a force of at least $200 \mathrm{kN}$ to loosen the restraining nut, while all but two of the inner-row tendons required only a low ram pressure to unseat the nut.

Upon completion of the detensioning operation, one of the tendons that failed was removed. It appeared to have failed near the bottom anchor, and as indicated by the darkened appearance of some of the fracture surfaces, the wires had evidently failed prior to detensioning. The investigation of the mechanism of these tendon failures is discussed in Sect. 7.3 .

After the circumferential prestressing assemblies were removed, the model was stripped and the inner concrete core (shown in Fig. 1.3) removed. A visual examination of the liner did not reveal any buckling, cracking, or other problems. Portions of the steel liners were removed at the six locations designated as cut sections in Fig. 7.2, and the exposed portions of the axial tendon assemblies were capped and sealed, as shown in Fig. 7.3, to prevent contamination during sectioning of the concrete. The model outer ring was transported to a commercial marble company for sectioning. The ring was first cut in half using a water-cooled (nonchlorinated well water) diamond wire sdw; additional sectioning was done using a diamond 
ORNL-OWG 73-7190R
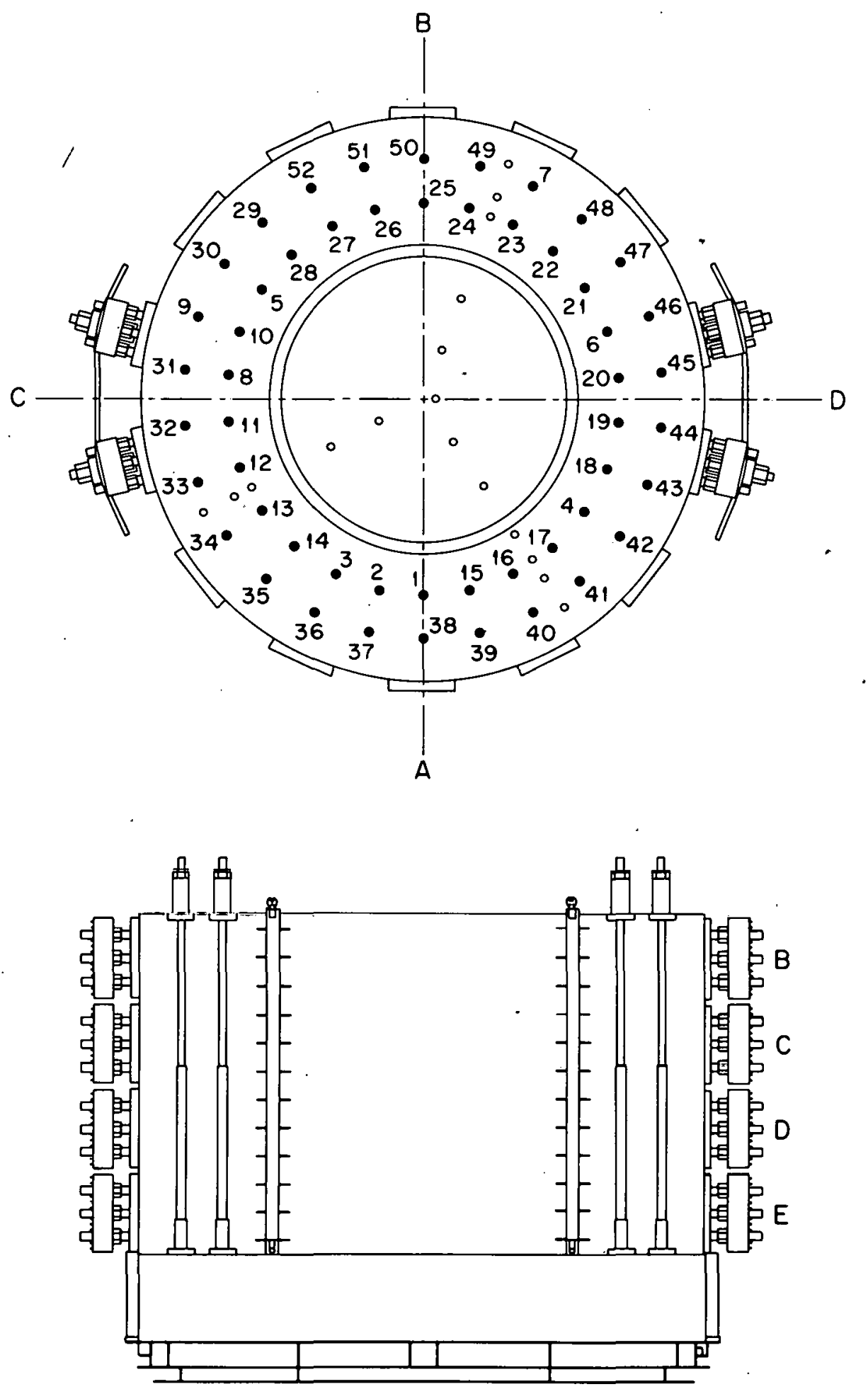

Fig. 7.1. Thermal cylinder prestressing system. 


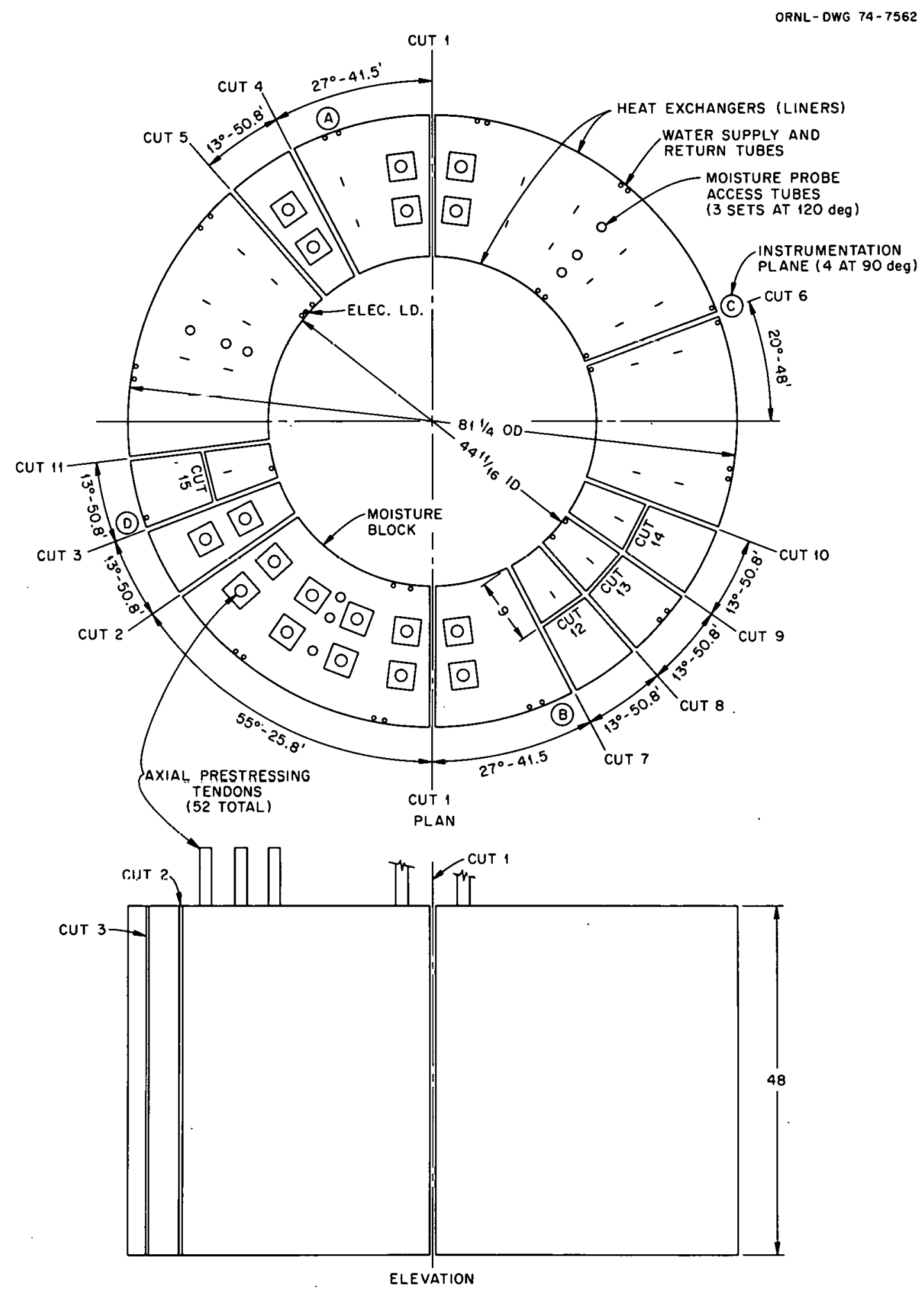

Fig. 7.2. Thermal cylinder model sectioning plan [dimensions not otherwise identified il rigure are $1 \mathrm{n}$ inches $(1 \mathrm{in} .=25.4 \mathrm{~mm}) 1$. 


$$
\text { ORNL- DWG } 74-7561
$$

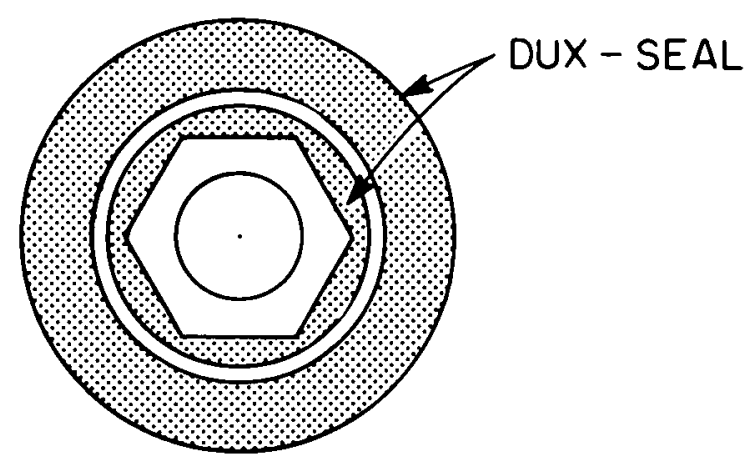

PLAN SECTION

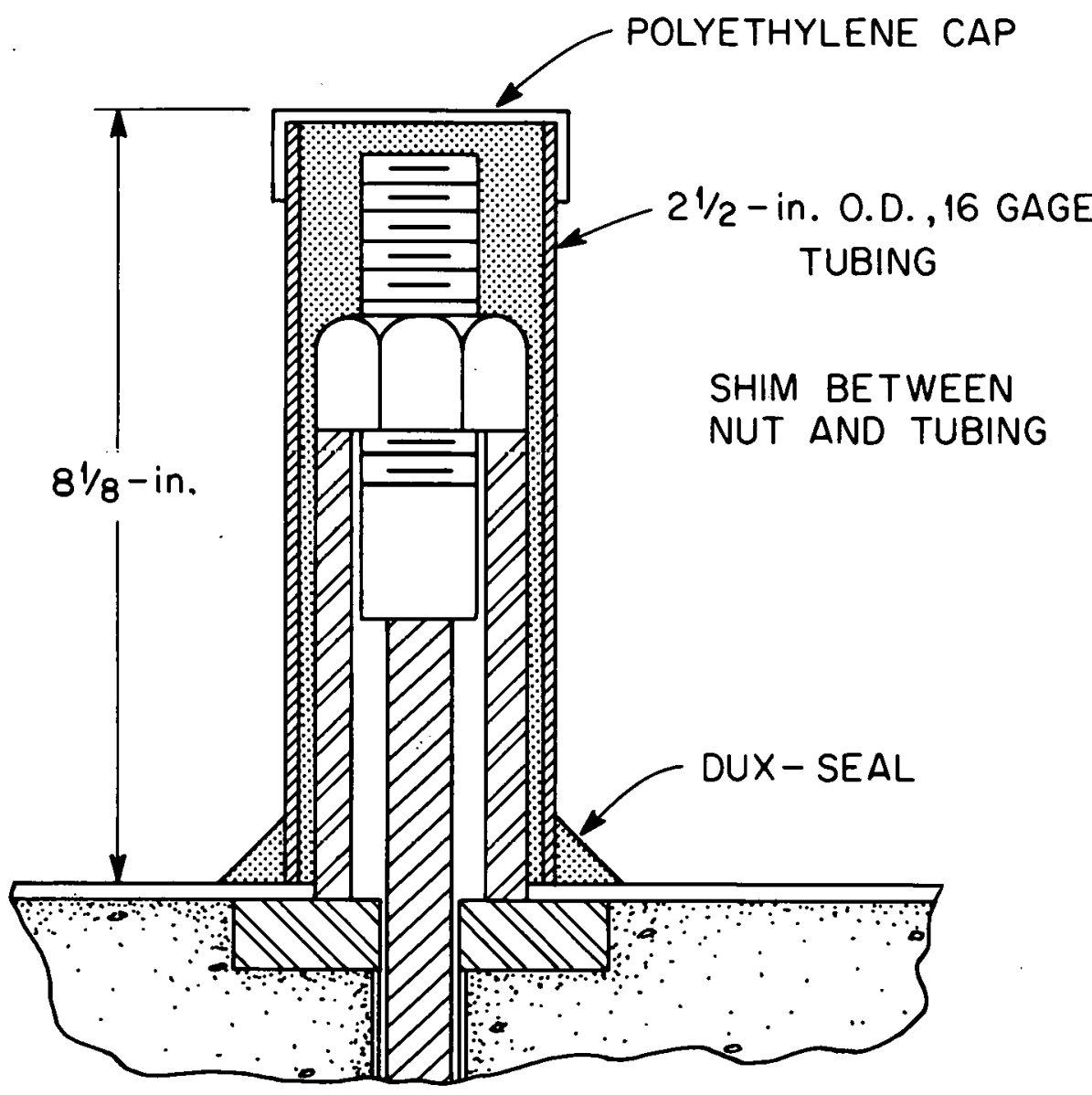

Fig. 7.3. Axial prestressing tendon assembly moisture seal for concrete sectioning $(1$ in. $=25.4 \mathrm{~mm}$ ). 
circular saw. The portion of the test section labeled "moisture block" in Fig. 7.2 was further sectioned, as shown in Fig. 7.4, to provide the 30.5by $30.5-$ by $30.5-\mathrm{cm}$ moisture test cube containing a stainless steel moisture probe access tube at the center. The use of this test cube in calibrating the moisture probe was described in Sect. 6.5.

Visual inspection of the exposed cross sections revealed no significant defects or structural cracks in the concrete. The slices made at the instrumentation section showed good bonds between the various gages and the concrete. The previously mentioned bonding problems with the wound-wire resistance embedment gages, which we assumed had occurred, were not discernible in the sliced sections.

The section produced by cut 15 (see Fig. 7.2) is shown in Fig. 7.5. The centermost gage label is to the right and below a precast three-gage rosette of single-filament resistance strain gages. A closeup of the excellent bond between the precast gage rosette and the remaining concrete is shown in Fig. 7.6. The upper gage shown in Fig. 7.5 is an axially oriented type A vibrating-wire gage, and the lower one is a radially oriented gage of the same type, with its activator coil housing and one end anchor exposed to view. The crack shown to the right of the upper gage occurred during the cutting operation, and the remaining inclusions seen in the concrete are primarily sectioned instrumentation leads.

\subsection{Rebound Hammer Test}

A1though there were no signiticant defects seen in the cut surfaces, the concrete immediately surrounding the hot-spot heating elements was darkened, as shown in Fig. 7.7, which indicates that some change occurred in the concrete due to the $505.4 \mathrm{~K}$ hot-spot heating. A series of readings were made on the concrete faces using an impact hammer (or sclerometer) in order to quantify any change in the concrete properties. This test is based on the principle that the rebound of an elastic mass depends on the hardness of the surface against which the mass impinges. The compressive strength of materials can be determined from this behavior. The test apparatus consists of a spring-loaded mass having a fixed amount of energy imparted to it by extending a spring to a predetermined compression. When 

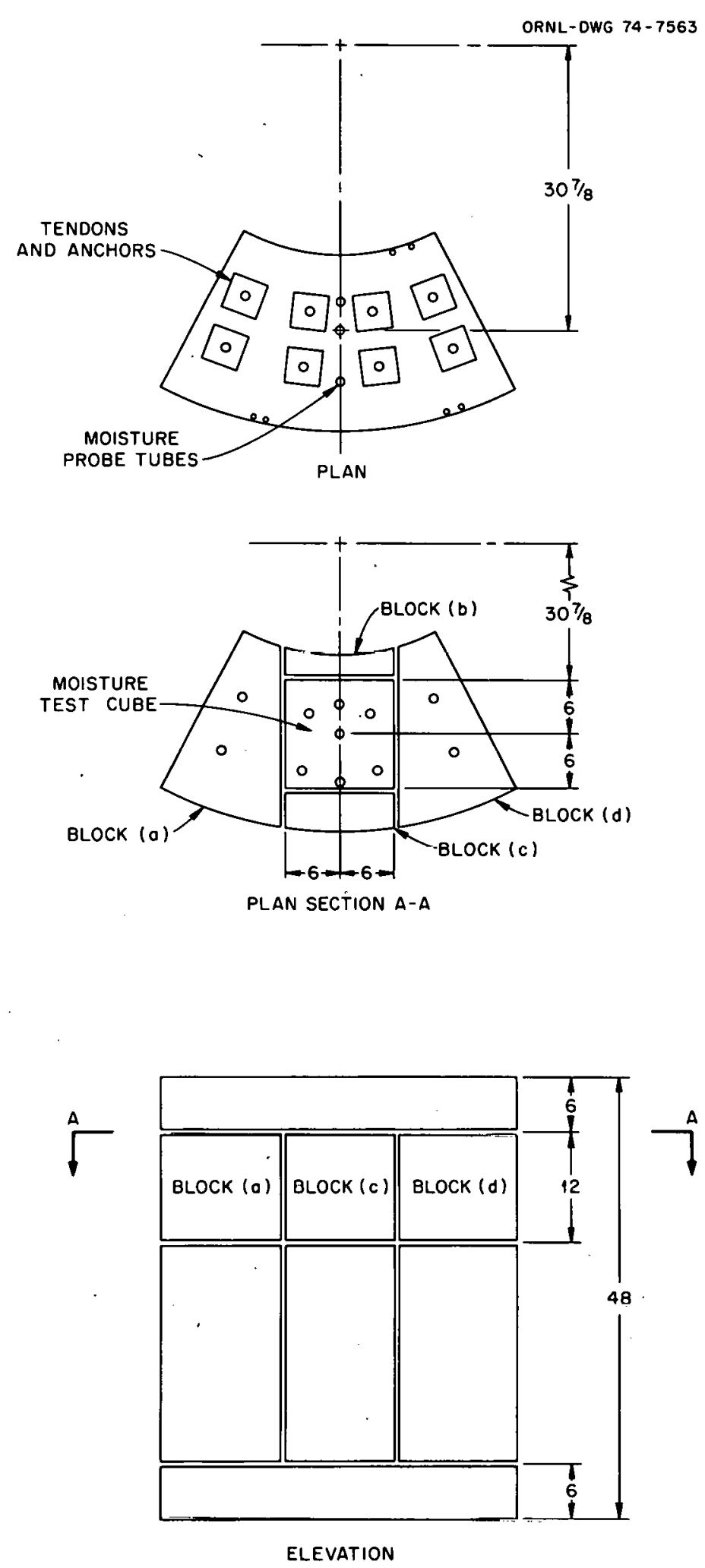

Fig. 7.4. Cutting plan for moisture block section of thermal cylinder model [dimensions in inches $(1$ in. $=25.4 \mathrm{~mm})$ ]. 


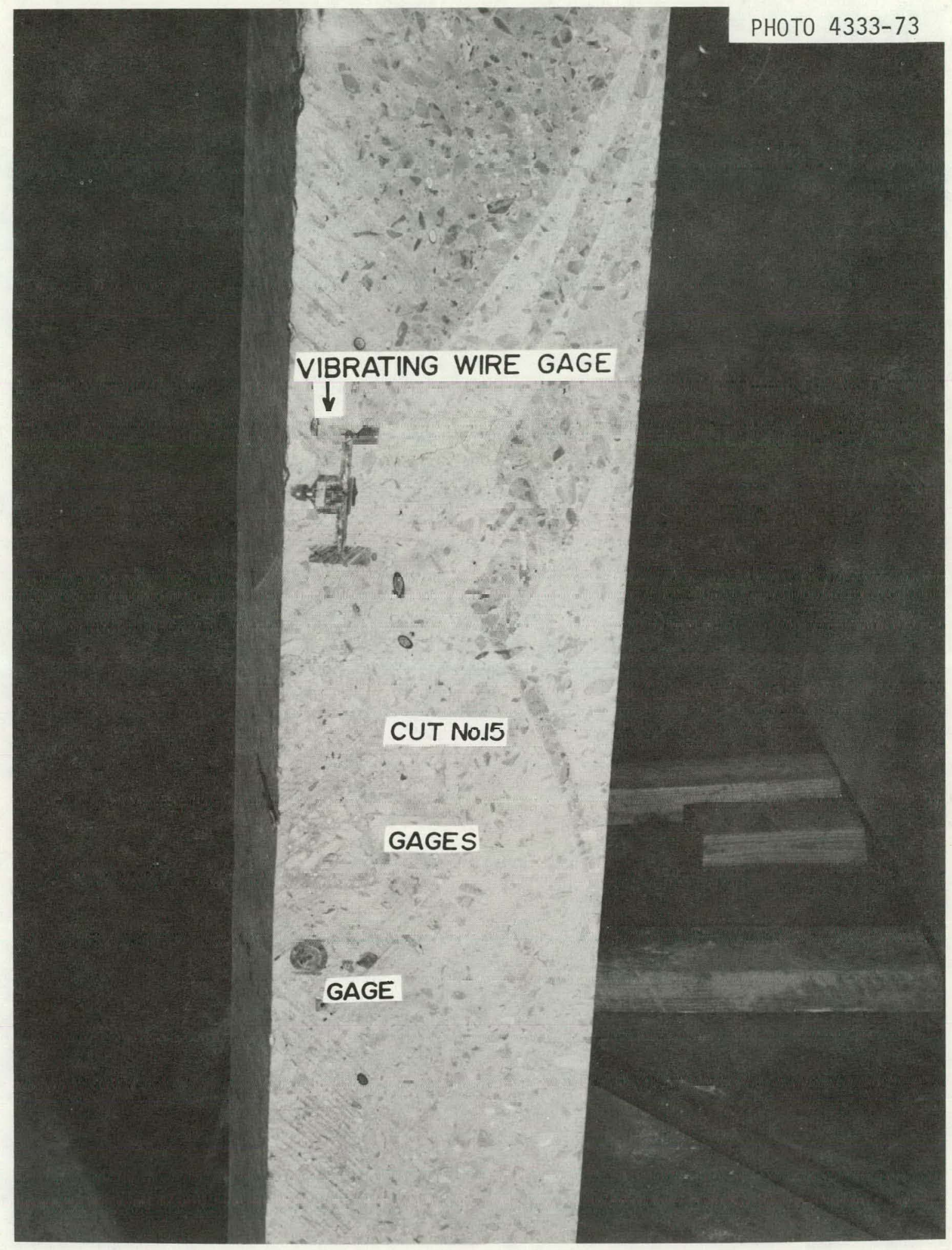

Fig. 7.5. Thermal cylinder model section produced by cut 15 . 


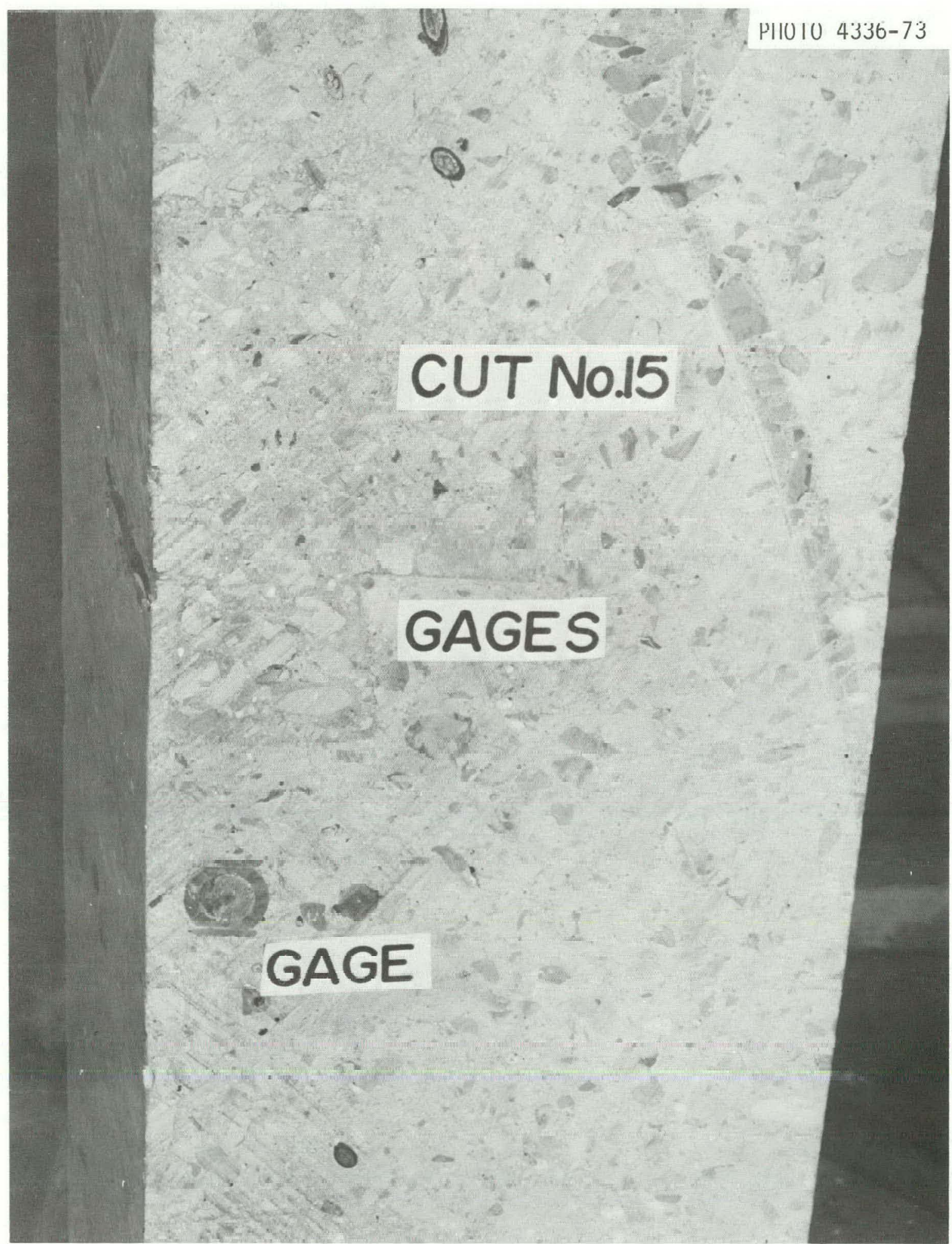

Fig. 7.6. Closeup of cut 15 showing bond between precast singlefilament resistance gage rosettes and model concrete. 


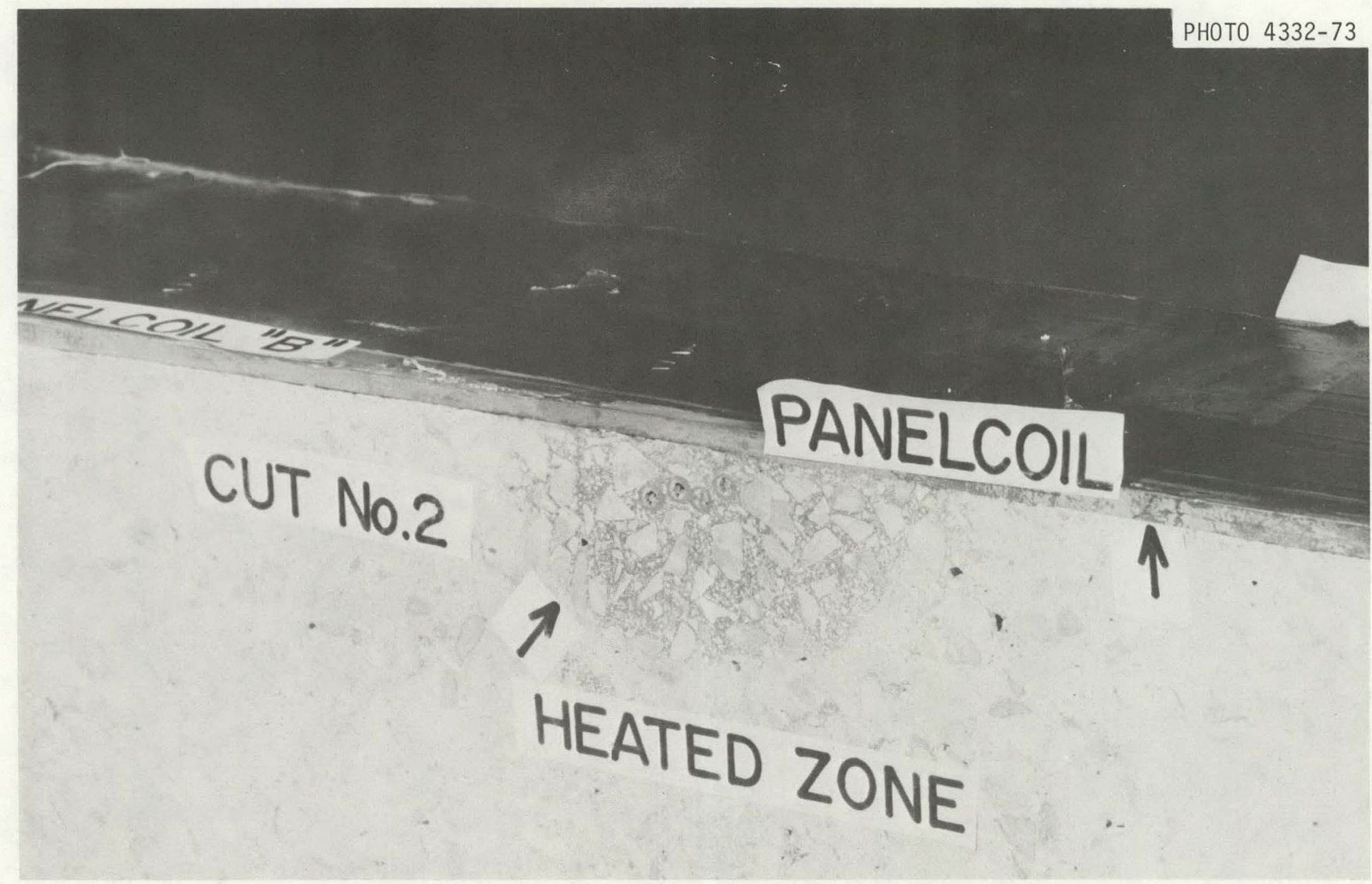

Fig. 7.7. Cross section of cut 2 showing discoloration in the vicinity of the hot-spot heating coils. 
released, the mass, or hammer, strikes the surface being tested and then rebounds; the distance traveled by the rebounding hammer, expressed as a percentage of the initial extension of the spring, is called the rebound number. This number is an arbitrary measure, since it depends on the energy stored in the given spring and on the size of the hammer.

The test is sensitive to local variations in the concrete; for example, the presence of a large piece of aggregate immediately beneath the plunger would result in an abnormally high rebound number, whereas the presence of a void in a similar position would result in a relatively low number. A correlation of rebound number with unconfined compressive strength is given by Neville $e^{9}$ for a concrete made with crushed limestone aggregate; in Fig. 7.8, this curve is extended to include a compressive strength of $55.2 \mathrm{MPa}$.

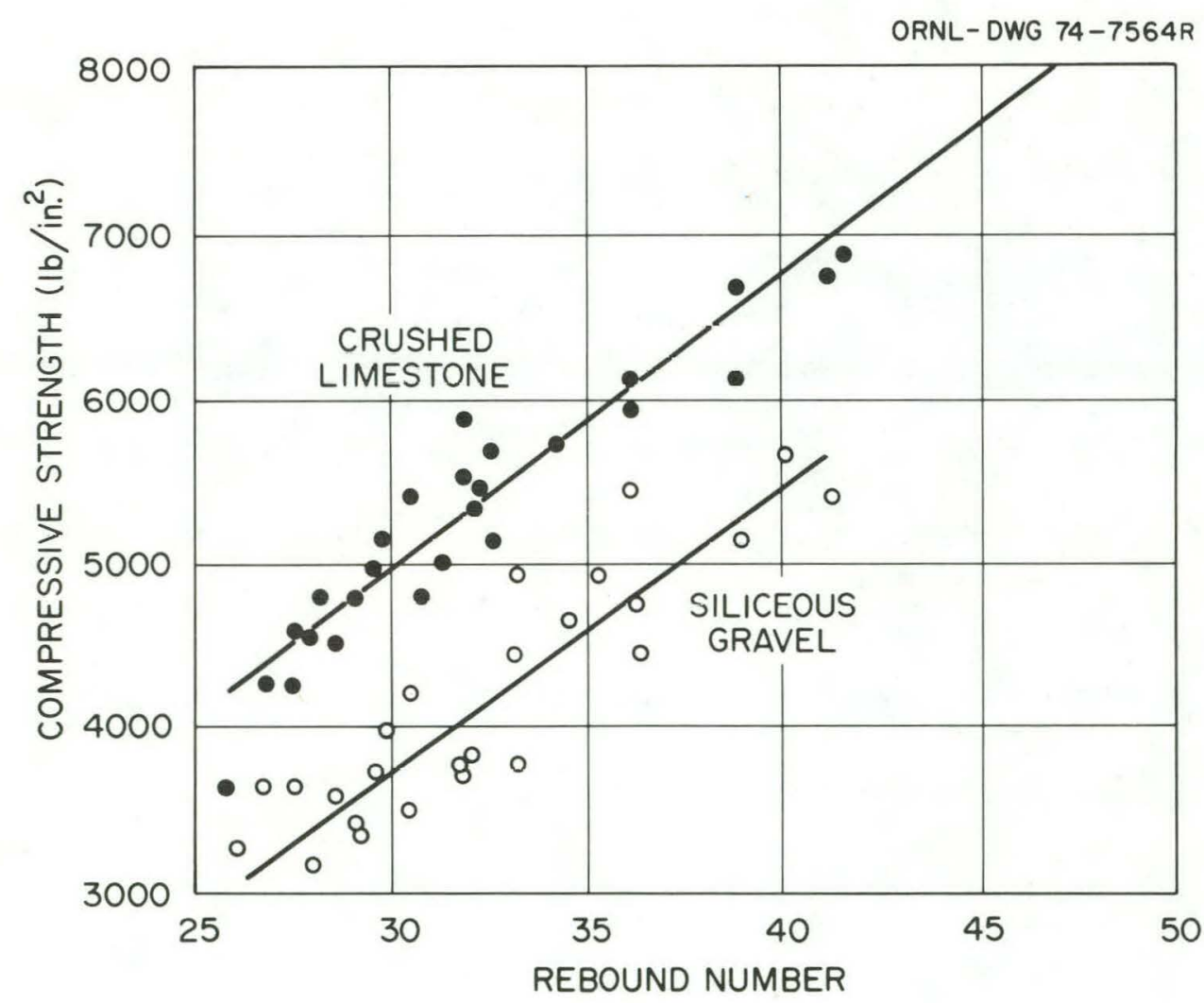

Fig. 7.8. Relationship between compressive strength and rebound number for concrete cylinders made with different aggregates. Readings taken on the side of a cylinder with the hammer horizontal. $\left(1 \mathrm{lb} / \mathrm{in} .^{2}=\right.$ $6895 \mathrm{~Pa}$. 
The results of a rebound test of the sectioned thermal cylinder model are shown in Table 7.1. Rebound readings were taken on the four faces of the cross section at the $A$ and $B$ quadrants. Readings were made along lines constructed perpendicular to the inside surface of the cylindrical test sections at two elevations, as shown in Fig. 7.9. One base set was taken in the upper part of the model approximately $0.3 \mathrm{~m}$ from the top, and one was taken through the vertical center of the hot-spot heated zone. The distances shown in the table were taken from the inside surface of the section. The "at heater" readings were taken directly adjacent to the Panelcoil heaters. As can be seen in the table, considerable compressive strength reductions were measured in the local heat-affected zone. This zone was easily distinguished by the distinct color change when compared with the rest of the cross section. On the other hand, the base readings taken at a considerable distance from the heat-affected zone show very little strength variation. The average strength determined from the base

Table 7.1. Summary of impact hammer (or sclerometer) readings on thermal cylinder model cross sections

\begin{tabular}{|c|c|c|c|c|c|c|c|c|c|}
\hline \multirow{3}{*}{$\begin{array}{l}\text { Distance } \\
{[\mathrm{cm}(\mathrm{in} .)]}\end{array}$} & \multirow{2}{*}{\multicolumn{3}{|c|}{ Base readings }} & \multicolumn{6}{|c|}{ Readings at hot-spot level } \\
\hline & & & & \multicolumn{2}{|c|}{ A section } & \multicolumn{2}{|c|}{ B section } & \multirow{2}{*}{ Average } & \multirow{2}{*}{$\begin{array}{l}\text { Compressive } \\
\text { strength } \\
{[\mathrm{MPa}(\mathrm{psi})]}\end{array}$} \\
\hline & A & B & Average & 1 & 2 & 1 & 2 & & \\
\hline At heater & & & & 31 & 23 & & 30 & 28.00 & $31.72(4600)$ \\
\hline $2.54(1)$ & 43 & 41 & 42 & 38 & 40 & 38 & 34 & 37.50 & $43.44(6300)$ \\
\hline 7.62 (3) & 43 & 44 & 43.5 & 42 & 40 & 43 & 39 & 41.00 & $47.57(6900)$ \\
\hline $12.70(5)$ & 45 & 46 & 45.5 & 41 & 40 & 40 & 43 & 41.00 & $47.57(6900)$ \\
\hline 17.78 (7) & 43 & 43 & 43.0 & 41 & 41 & 43 & 43 & 42.00 & $48.95(7100)$ \\
\hline $22.86(9)$ & 44 & 43 & 43.5 & 48 & 41 & 42 & 44 & 43.75 & $51.71(7500)$ \\
\hline 27.94 (11) & 43 & 44 & 43.5 & 43 & 43 & 43 & 45 & 43.50 & $51.71(7500)$ \\
\hline 33.02 (13) & 43 & 44 & 43.4 & 42 & 45 & 43 & 45 & 43.75 & $51.71(7500)$ \\
\hline 38.10 (15) & 44 & 45 & 44.5 & $49^{a}$ & 43 & 44 & 44 & 43.70 & $51.71(7500)$ \\
\hline 43.18 (17) & 43 & 45 & 44.5 & 42 & 47 & 42 & 44 & 43.75 & $51.71(7500)$ \\
\hline
\end{tabular}

$a_{\text {Excessively high readings taken on aggregates were not included in }}$ the average; readings for large aggregate inclusions were 50 . 


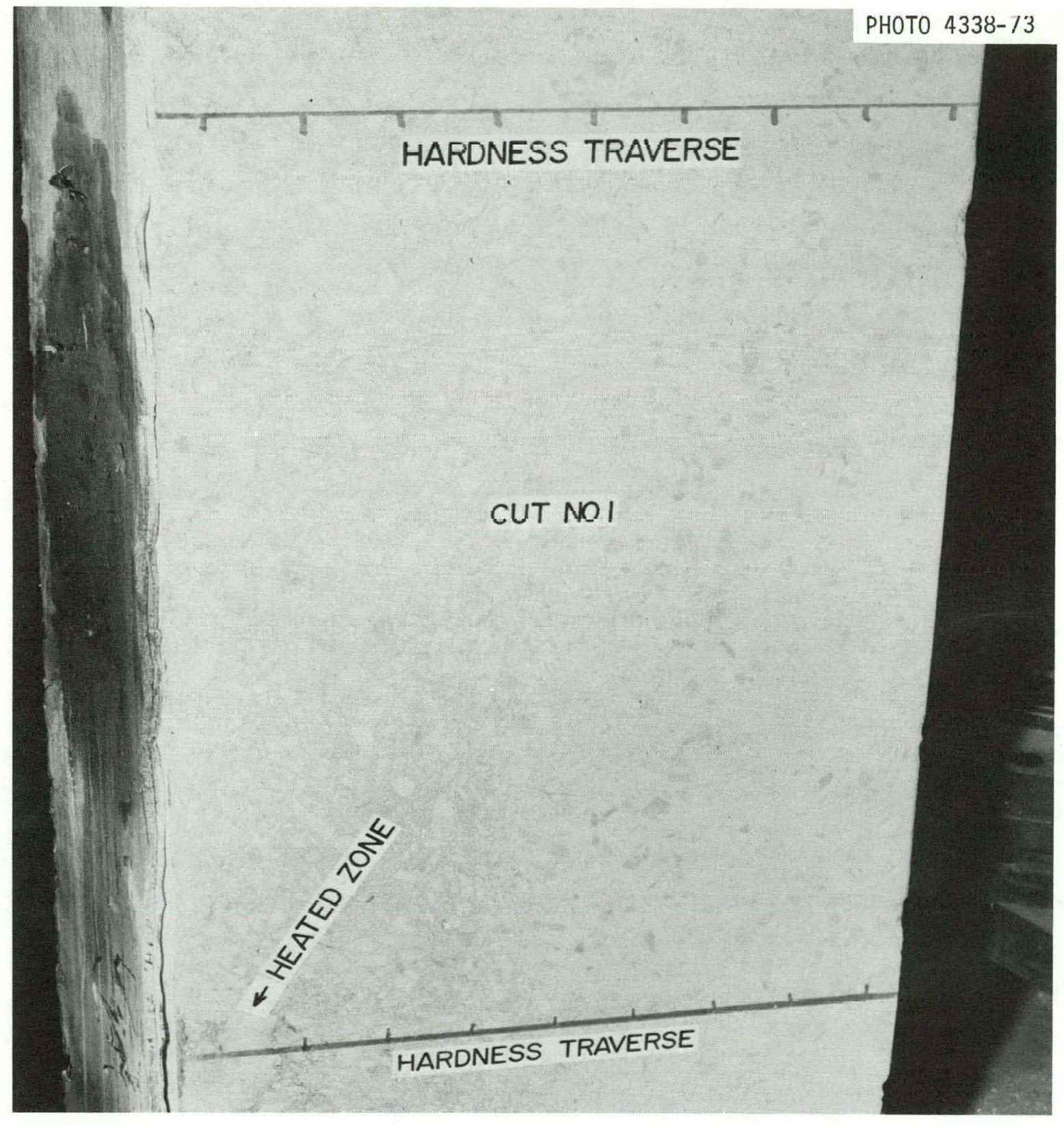

Fig. 7.9. Concrete rebound test traverse lines for concrete section of cut 1 .

readings was $51.7 \mathrm{MPa}$. There is little doubt that a significant loss of strength occurred in the heat-affected zone. The thermal cylinder had a 28-day unconfined compressive strength of approximately $48.3 \mathrm{MPa}$, which may indicate that the rebound reading strength correlation may be slightly low. However, these readings were taken on the matrix rather than on the 
aggregates whenever possible. The rebound readings made on large aggregates were significantly higher.

\subsection{Prestressing Tendon Corrosion}

An investigation was conducted to determine the causes of the tendon failures described in sect. 7.1. The condition of the 26 inner-row and outer row tendons is summarized in Table 7.2. The location in the model of each tendon listed is shown in Fig. 7.1 .

\subsubsection{Description of axial tendons}

Each tendon was a 1.52-cm-diam LOK-STRESS monostrand consisting of seven wires and having S.E.E.E. anchors attached to both ends. These strands were manufactured in accordance with ASTM A416 and were specified in this case to minimize possible relaxation losses. They have a modulus of elasticity of $193 \mathrm{GPa}$ and a breaking strength of 1,724 MPa.

The tendons were coated with a widely used, commercial corrosionprotection material when received from the manufacturer. A total of 12 tendons, 6 in each row, were instrumented with load cells at the top anchor and foil-type electrical resistance strain gages on one wire of each strand. It was necessary to remove the original protective coating from an approximately $30.5-\mathrm{cm}$ section of the instrumented wire in order to install the gage. These were the only tendons from which any of the original corrosion protection was removed. After the strain gage was installed, the tendon was waterproofed with a commercial wax, using methods recommended by the Portland Cement Association. ${ }^{10}$ The specific wax employed is generally recognized as being effective for corrosion protection. The tendons were housed in two-piece telescoping ducts in the manner shown in Fig. 7.10. First the joint at the bottom anchor fitting was sealed with heat-shrinkable Flexite tubing, and the lower duct section was filled with melted wax. Then the upper joint was sealed with Flexite tubing, and the upper duct section was filled with melted wax. The known volume of wax required to fill each tendon assembly was used to indicate whether the duct was completely filled. When properly fitted, the Flexite tubing bulged slightly. As a final step, the lower end of the bottom anchor fitting was sealed with melted max. 
Table 7.2. Axial tendon examination of PCRV thermal cylinder model

\begin{tabular}{|c|c|c|c|c|}
\hline $\begin{array}{l}\text { Tendon } \\
\text { No. }\end{array}$ & Row $^{a}$ & $\begin{array}{l}\text { Load cel1 } \\
\text { designation }\end{array}$ & Failure location & Remarks \\
\hline 1 & $\mathrm{I}$ & ATR-11 & Broke near bottom anchor & Failed at time of detensioning $b$ \\
\hline 2 & $\mathrm{I}$ & None & Broke near bottom anchor & Failed at time of detensioning \\
\hline 3 & I & None & Broke near bottom anchor & Failed at time of detensioning \\
\hline 4 & I & None & Broke near bottom anchor & Failed at time of detensioning \\
\hline 5 & $\mathrm{I}$ & None & Broke near bottom anchor & Failed at time of detensioning \\
\hline 6 & I & None & Broke near bottom anchor & Failed at time of detensioning \\
\hline 7 & 0 & None & Failed at top & Failed at $0.256 \mathrm{MN}(57,500$ 1b) \\
\hline 8 & $\mathrm{I}$ & CTR-3 & Failed near center & Failed at $0.037 \mathrm{MN}(8400 \mathrm{lb})$ \\
\hline 9 & 0 & None & $\begin{array}{l}\text { Wire pulled through top } \\
\text { anchor }[1.27-\mathrm{cm}(0.5-\mathrm{in} .) \\
\text { wire in enchor) }\end{array}$ & $\begin{array}{l}\text { Stopped at } 0.26 \mathrm{MN}(60,000 \mathrm{lb}) \text { wire } \\
\text { slipping in anchor }\end{array}$ \\
\hline 10 & I & None & & Failed at time of detensioning \\
\hline 11 & I & CTR-1 & & Failed during test (see load cell data) \\
\hline 12 & I & None & Broke near top anchor & Failed at $0.028 \mathrm{MN}(6200 \mathrm{1b})$ \\
\hline 13 & I & None & & Failed at time of detensioning \\
\hline 14 & I & None & & Failed at time of detensioning \\
\hline 15 & I & None & & Failed at time of detensioning \\
\hline 16 & I & None & & Failed at $0.191 \mathrm{MN}(43,0001 \mathrm{~b})$ \\
\hline 17 & $\mathrm{I}$ & None & & Failed at time of detensioning \\
\hline 18 & I & None & & Failed at $0.102 \mathrm{MN}(23,000 \mathrm{lb})$ \\
\hline 19 & I & DTR-9 & Failed neer top anchor & Failed at $0.267 \mathrm{MN}(60,000 \mathrm{lb})$ \\
\hline 20 & I & DTR-7 & & No indication of failure \\
\hline 21 & I & None & Failed neer bottom anchor & $\begin{array}{l}\text { Failed at } 0.254 \mathrm{MN}(57,000 \mathrm{1b}) \text { (one wire } \\
\text { shows cracks) }\end{array}$ \\
\hline 22 & I & None & & Failed at time of detensioning \\
\hline 23 & I & None & & Failed at $0.138 \mathrm{MN}(31,0001 \mathrm{~b})$ \\
\hline 24 & I & None & & Failed at $0.129 \mathrm{MN}(29,000 \mathrm{1b})$ \\
\hline 25 & I & BTR-5 & & Failed during test (see load cell data) \\
\hline 26 & I & None & & Excessive yielding at $0.145 \mathrm{MN}(32,500 \mathrm{1b})$ \\
\hline 27 & I & None & & Failed at time of detensioning \\
\hline 28 & I & None & & Excessive yielding at $0.147 \mathrm{MN}(33,000 \mathrm{lb})$ \\
\hline
\end{tabular}




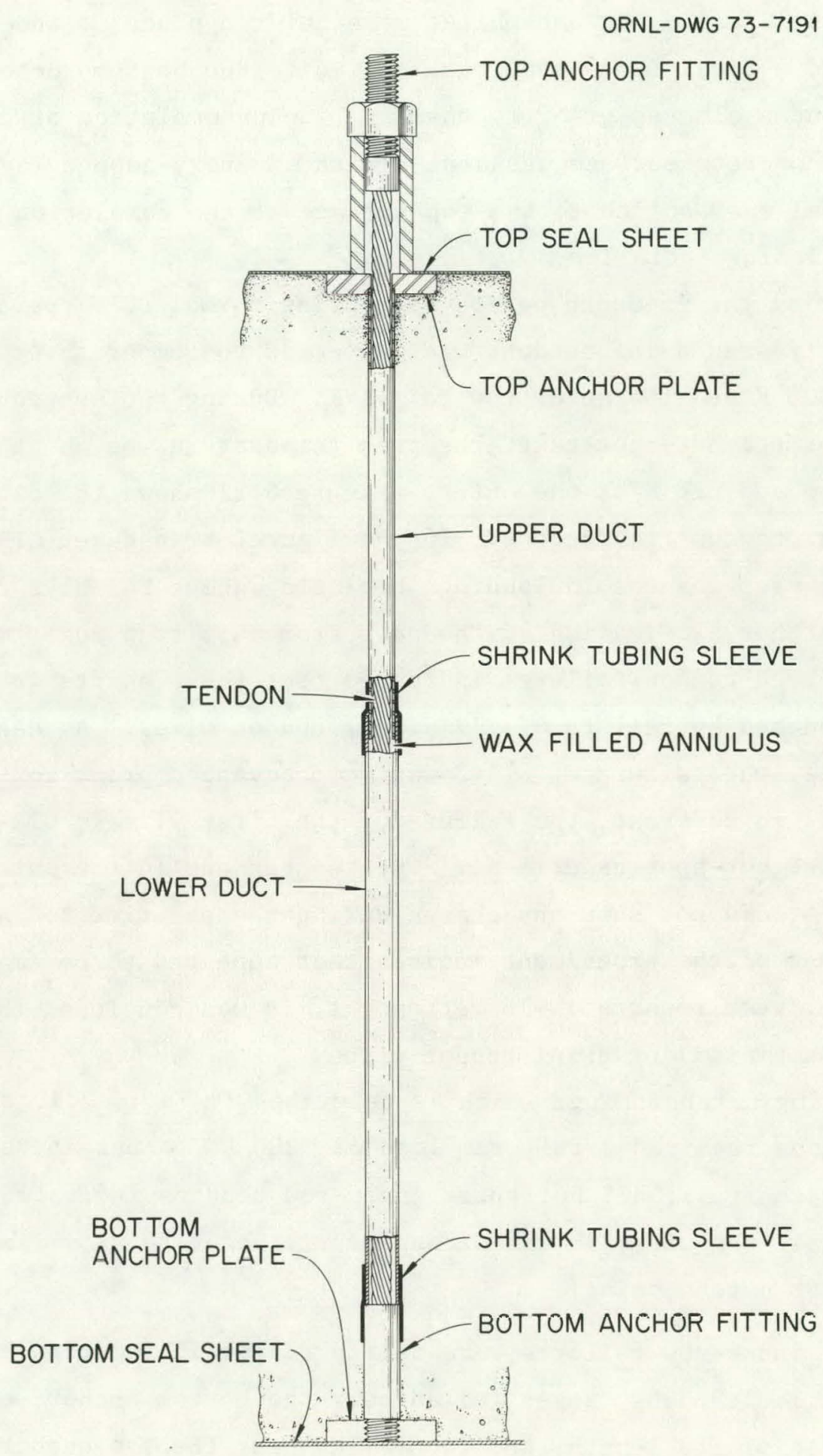

Fig. 7.10. Axial tendon assemb1y detail. 
The sealed tendon assemblies were positioned in the structure as shown in Fig. 1.3, and the bottom anchor plates were tack welded onto the bottom sheet-metal seal. The assemblies were held in place at the top by a fixture, and a final epoxy seal was applied to the bottom anchor plates and lower tendon sleeves prior to casting. Upon completion of casting, the exposed concrete surface was sealed with an epoxy-copper layer. A final epoxy seal was applied to the top surface at the completion of the tendon posttensioning operation.

During the 15-month period simulating normal PCRV operation, the inner row of stressed axial tendons was subjected to temperatures of approximately $325 \mathrm{~K}$ and the outer row to $311 \mathrm{~K}$. During the subsequent 3 -month period of the hot-spot test, the peak temperature was about $380 \mathrm{~K}$ at the inner row and $328 \mathrm{~K}$ at the outer. Figure 6.21 shows the data for four of the axial tendon transducers. In the figure, transducer CTR-3 shows significant step changes in loadings beginning about 245 days from prestressing. Further examination of the data from this transducer made in light of the observed tendon failures indicated that these shifts in load readings were produced by failure of individual tendon wires. As can be seen in Fig. 6.21, the failure of CTR-3 was well advanced prior to the hot-spot heating. In contrast, the failure of the first wire in CTR-1 occurred during the hot-spot experiment. The two tendons in the outer row, CTR-2 and CTR-4, did not show any change during the experiment. Also, during the course of the experiment, noises that appeared to be emanating from the model were reported. In retrospect, it was concluded that these sounds were made by failing axial tendon wires.

During detensioning, which is described in Sect. 7.1, all the outerrow tendons required a full ram load of $\sim 200 \mathrm{kN}$ to unseat the restraining nut. In contrast, all but three inner-row tendons indicated failure of some or all the wires in the strand by virtue of the low ram pressure required for detensioning.

The inner-row failures were fairly random in location. Of the ten fully failed tendons, seven failed near the bottom anchor, one failed near the middle of its length, and two failed near the top anchor. In contrast, during a selective reloading of outer-row tendon 6 , the top anchor fitting, 
shown schematically in Fig. 7.10, was pulled almost through the entire length of strand to which it was swaged without inducing wire failure.

\subsubsection{Metallurgical and chemical analyses}

An example of a typical wire fracture is shown in Fig. 7.11. All the failures contained a flat semielliptical initiation site and, when the net area of the wire was unable to sustain the applied load, a ductile cup-cone fracture. The initiation site in the wire shown in Fig. 7.11 contained sulfur, but this was not necessarily true of all the failures.

The results of a chemical analysis of the as-received protective agents and the wax remaining in the tendon ducts are provided in Table 7.3. It was evident that the wax in the ducts contained large quantities of nitrogen. Although the exact chemical form of the nitrogen was not determined, the wax displayed a strong odor of ammonia when it was initially removed from the ducts. This was true for both inner- and outer-row tendons. The presence of nitrogen has been attributed to the use of an excessive amount of hardener in the epoxy sealer, since hardeners used with epoxy resins contain organic amines which can hydrolyze in the presence of water to produce ammonia. Visual imspection of the polyvinyl fluoride shrink tubing on several of the removed tendons indicated that the tubing was ineffective in preventing ingress of water from the concrete.

An analysis of a quantity of liquid extracted from the tendon ducts showed it to be an aqueous solution containing nitrogen, chlorine, sulfur, and perhaps other substances. The nitrogen appeared to be mostly in the form of ammonia (or perhaps a volatile amine), but in a few cases low levels of nitrate ( $\sim 50 \mathrm{ppm})$ were also present. A complete analysis was not possible owing to the small quantity of liquid present in the ducts.

\subsubsection{Corrosion tests}

Various ammonium salts, such as nitrate and carbonate, are known to be capable of producing stress-corrosion cracking in steels. To determine whether the steel in question was susceptible to cracking in such environments, several U-bend specimens of the steel were exposed to various solutions that contained certain ammonium salts and the epoxy mixtures. 


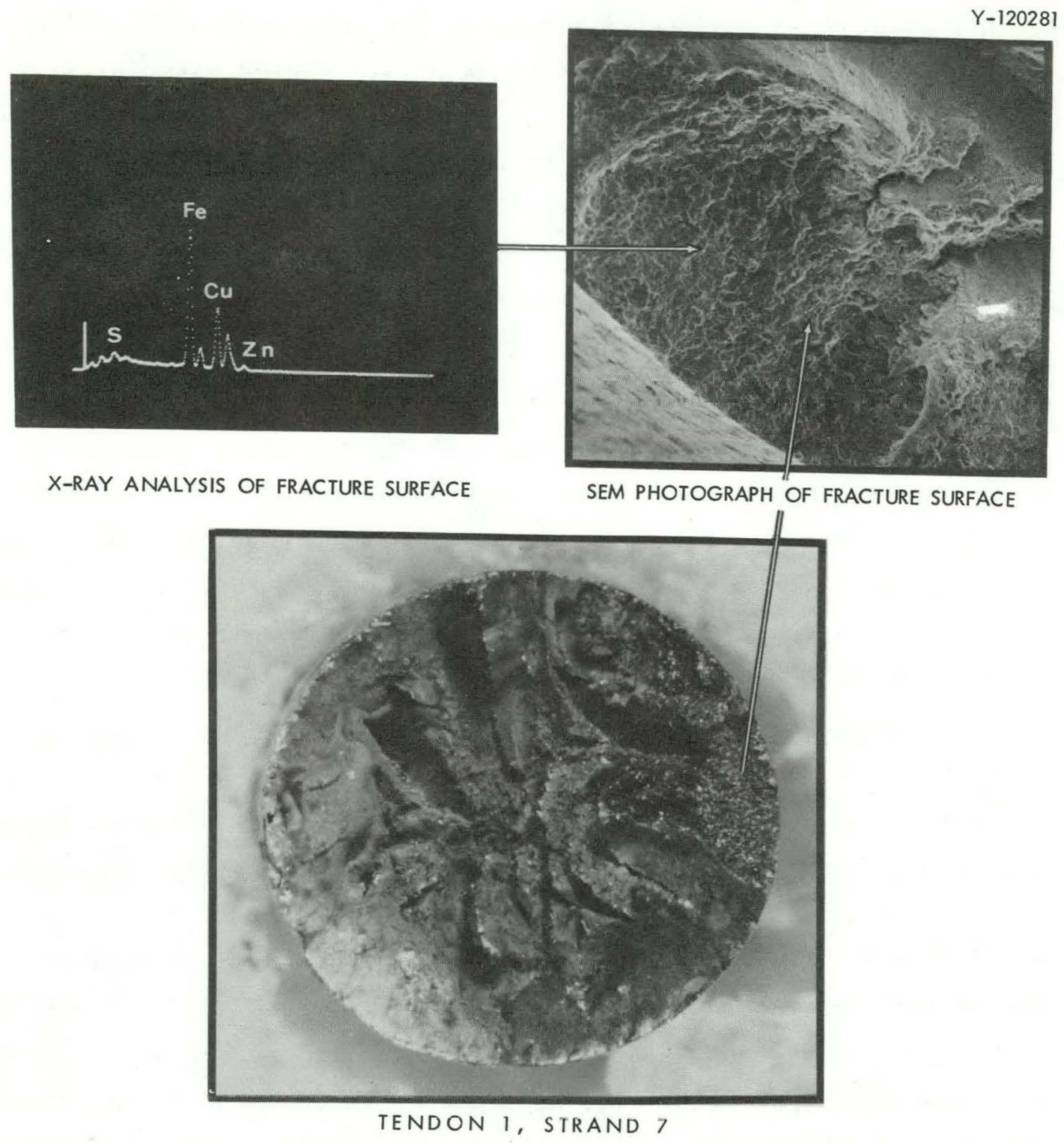

Fig. 7.11. Fractographic examination of failure surface in a wire from tendon 1. The flat area in the photomacrograph was viewed and analyzed in the scanning electron microscope. There is a definite indication of sulfur in the flat area of the fracture surface.

The test specimens were made from the center wires of uncracked circumferential tendons taken from the thermal cylinder experiment. The wires were ground to a diameter of $1.5 \mathrm{~mm}$ (by centerless grinding), and 76-mm lengths were bent into the small-radius U-shaped specimens shown in Fig. 7.12. The small specimens were placed in 25-ml Pyrex bottles containing $15 \mathrm{ml}$ of test solution, and the bottles were capped and then heated in a small oven at the desired temperature. 
Table 7.3 Chemical analysis of the thermal cylinder axial tendon protective agents

\begin{tabular}{|c|c|c|c|c|}
\hline \multirow{2}{*}{$\begin{array}{c}\text { Identification } \\
\text { of source } \\
\text { of wax }\end{array}$} & \multicolumn{4}{|c|}{ Level of contaminant (ppm) } \\
\hline & $\mathrm{C} 1$ & S & $\mathrm{N}$ & $\mathrm{H}_{2} \mathrm{O}$ \\
\hline As-received corrosion-protection material & $\begin{array}{l}3.1 \\
2.1 \\
2.4\end{array}$ & 1900 & 785 & 76 \\
\hline As-received commercial wax & $\begin{array}{l}3.6 \\
7.6 \\
2.7\end{array}$ & 3200 & 200 & 32 \\
\hline \multicolumn{5}{|l|}{ Wax removed from: } \\
\hline $\begin{array}{l}\text { Tendon } 19^{a} \\
\text { Tendon } 28^{a} \\
\text { Tendon } 44^{b}\end{array}$ & & & $\begin{array}{r}840 \\
6400 \\
1000\end{array}$ & $\begin{array}{r}1,900 \\
25,585 \\
24,800\end{array}$ \\
\hline
\end{tabular}

\footnotetext{
${ }^{a}$ Inner-row tendon that contained failed wire(s).

$b$ Outer-row tendon that did not contain a failed wire.
}

No cracks developed in specimens exposed either to an epoxy mixture (with or without $\mathrm{CO}_{2}$ ) or to the water equilibrated with them during exposures that lasted 94 days at $343 \mathrm{~K}$. Similar tests in the same environments but with $50 \mathrm{ppm}$ nitrate added produced no cracking during a 100-day test at $339 \mathrm{~K}$. Cracking was also absent in specimens exposed to concentrations of ammonium carbonate solutions under the same conditions, either with or without 50 ppm nitrate added.

Cracking occurred only in $0.2-$ and 2.0-M ammonium nitrate solutions. In the $0.2-M$ solution at $343 \mathrm{~K}$, duplicate specimens cracked in 3 days. Under the same conditions, the single specimen exposed to the 2.0-M solution cracked in the interval between 7 and 10 days. A specimen that failed is shown in Fig. 7.13. Failures in the other two U-bend specimens appeared to be almost identical to the one shown in the figure. The single specimen exposed to a saturated solution of ammonium nitrate at $343 \mathrm{~K}$ did not crack during the 94-day test.

The results of the U-bend tests show that the tendon material is susceptible to stress-corrosion cracking in $0.2-$ and $2.0-M$ ammonium nitrate, but not susceptible in very dilute solutions (50 ppm) nor in very 


\section{ONE INOH}

$1 \quad 1 \quad 1 \quad 1 \quad 1$

Fig. 7.12. The U-bend specimen used in the stress-corrosion studies. The 1.5-nm-diam steel test seztion was ground from a sound area of a wire renoved from a tendon in whici individual wires hac failed. The wire is bent inco the $U$ configuration, and its ends are placed in the refractory retainer. ( 1 in. $=25.4 \mathrm{~mm}$.) 

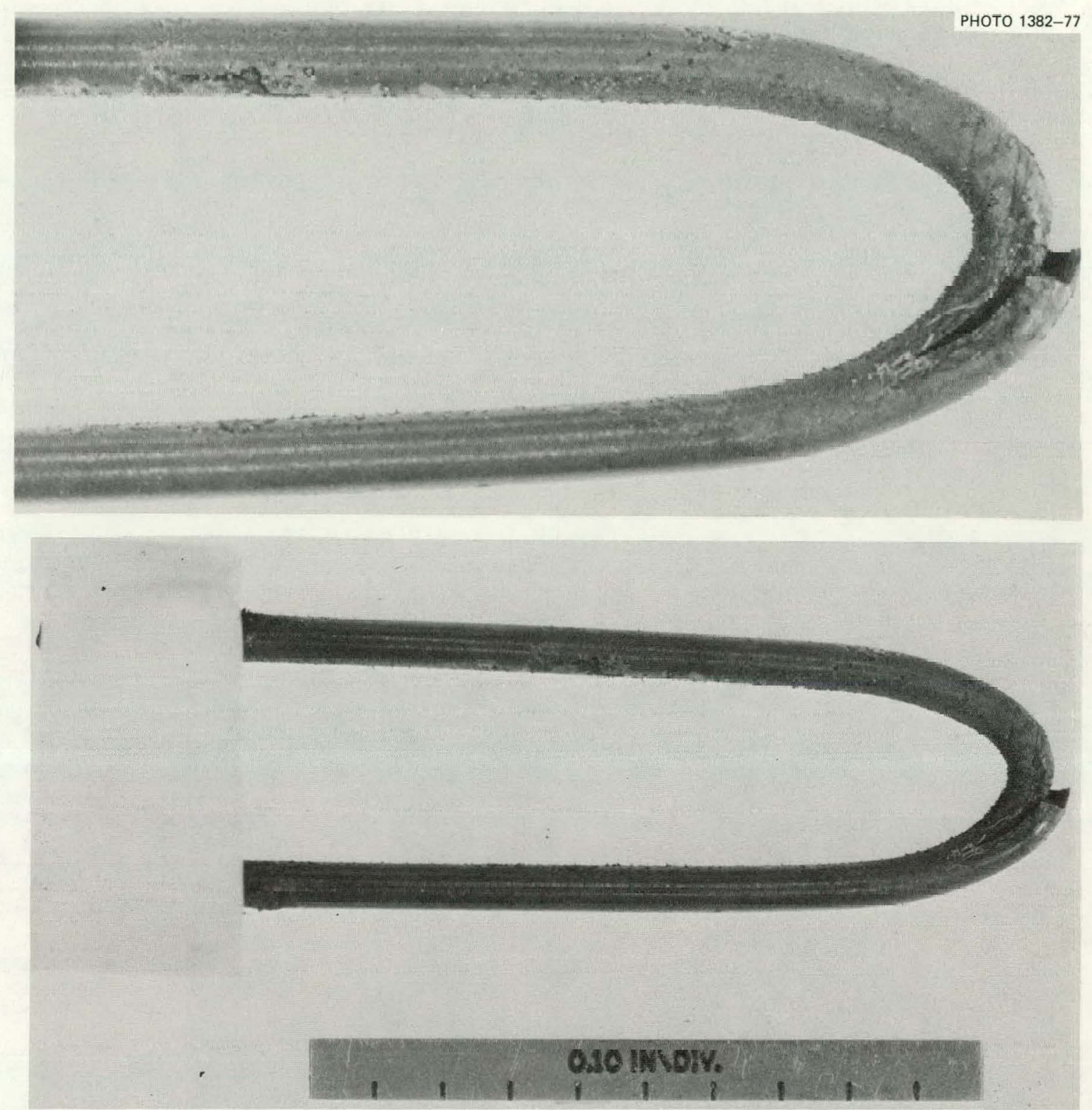

Fig. 7.13. U-bend stress-corrosion specimen that failed in a $0.2-M$ ammonium nitrate solution in $72 \mathrm{hr}$ at $343 \mathrm{~K}$ (1 in. $=25.4 \mathrm{~mm}$ ). (Original reduced $42.5 \%)$

concentrated solutions (saturated at test temperatures). However, in certain regions along the tendons, higher concentrations of the dilute nitrate solution could have developed, in which case cracking could have occurred. These results do not allow one to conclude unequivocally that ammonium nitrate was responsible for the observed cracking, but neither do they exclude the possibility that cracking resulted from the presence of nitrate in the aqueous environment. 


\subsubsection{Retension tests}

Tests were also conducted to determine whether the slight difference in temperature experienced by the outer (311 K) and the inner (325 K) row of tendons was responsible for the preponderance of failures in the inner row. Two pie-shaped segments were cut from the thermal cylinder model for the tests, one including tendons 15 and 39 and the other tendons 20 and 45 (see Fig. 7.1).

Each concrete segment was outfitted on the outer cylindrical surface with silicone rubber electric strip heaters and on the radial cuts immediately adjacent to the inside circumferential surface with Panelcoil heat exchangers, as shown in Fig. 7.14. Each tendon was equipped with a cali-

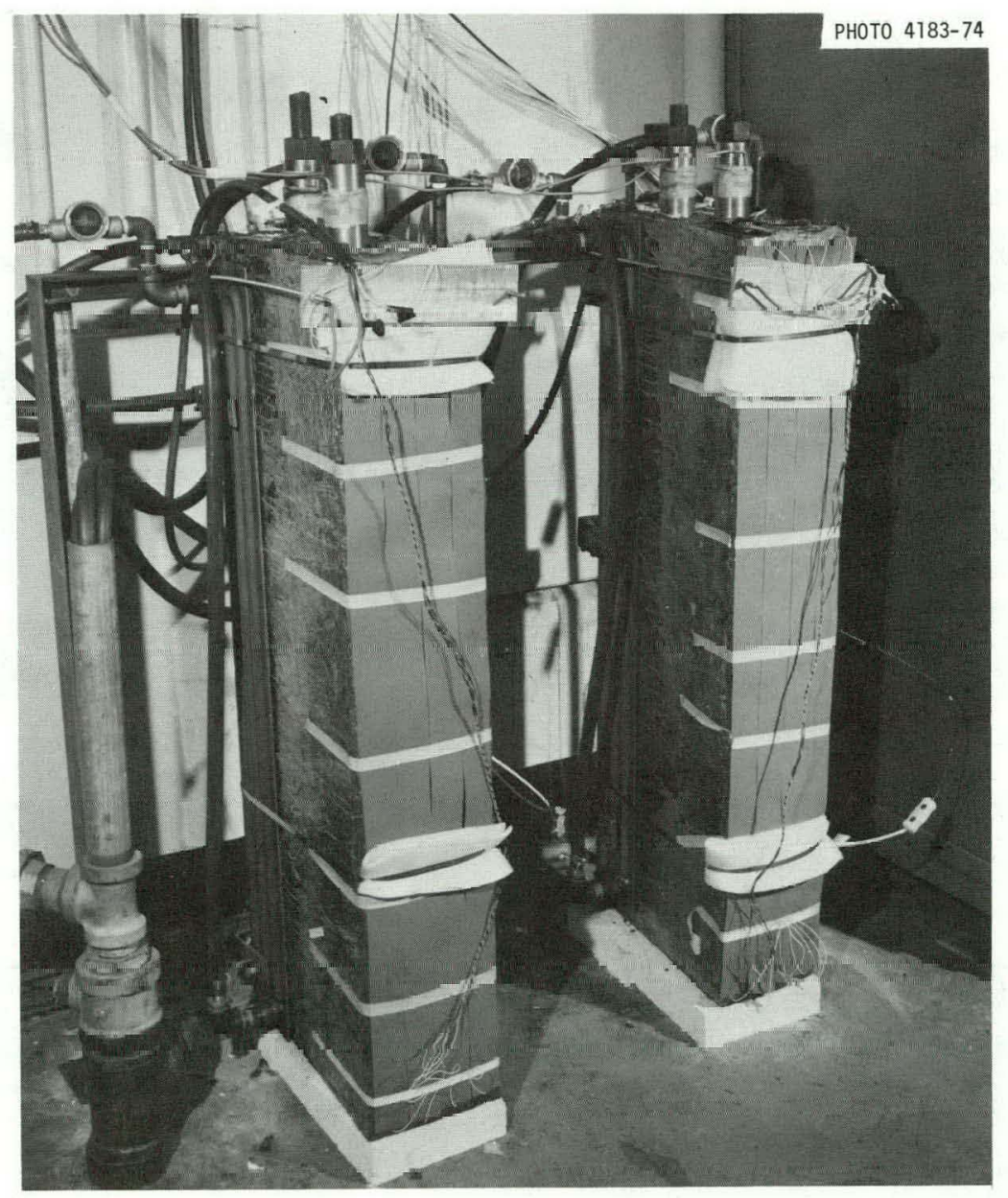

Fig. 7.14. Panelcoils and electric strip heaters installed on segments of thermal cylinder before insulation. 
brated load cell, the output of which was continuously recorded by a multipoint recorded. Thermocouples were embedded in the inner and outer cylindrical faces of the segments, and temperatures were also continuously recorded by the multipoint recorder. Heater input was controlled by a manually adjustable Variac voltage control and by a temperature controller.

Tendons 20 and 45 in one segment and tendon 39 in the second segment were subjected to a second tensioning. Tendon 45 was retensioned to the design load of $162.2 \mathrm{kN}$; tendons 39 and 20 were subjected to reduced loadings of $84.1 \mathrm{kN}$ and $86.7 \mathrm{kN}$, respectively; and tendon 15 remained unstressed, since it had failed during detensioning of the model. The electric heaters and Panelcoils were then used to impose thermal conditions of $339 \mathrm{~K}$ and $297 \mathrm{~K}$ on the outside and inside surfaces (a reversal of the thermal crossfall used with the original model). The tendon loads and temperatures of the segments were monitored continuously thereafter for a two-year period during which no significant change in load was detected. Thus, the reversed thermal gradient imposed on the segments had no observable effect. The cause of the preponderance of failures of inner-row tendons, therefore, remains unidentified.

\subsubsection{Assessment of wire quality}

Studies of randomly selected wires have revealed that the wires in the axial tendons used to prestress the thermal cylinder model were of questionable quality. Locating these defective areas in the axial tendon wires was fortuitous; radiographic examinations of randomly selected wires removed from the circumferential tendons did not reveal any defects, but metallographic examination revealed some hairline cracks. Figures 7.15 and 7.16 are typical of the types of defects observed. These cracks are not detectable by the usual examination standards.

During centerless grinding of the wires used for U-bend stress-corrosion test specimens, one wire separated into two pieces. A metallographic examination of the wire revealed several fissure-like cracks which could serve as locations both for the concentration of contaminants present and for the development of stress concentrations (see Fig. 7.17). Thus, these cracks could have contributed to the failures observed during the thermal cylinder test. 


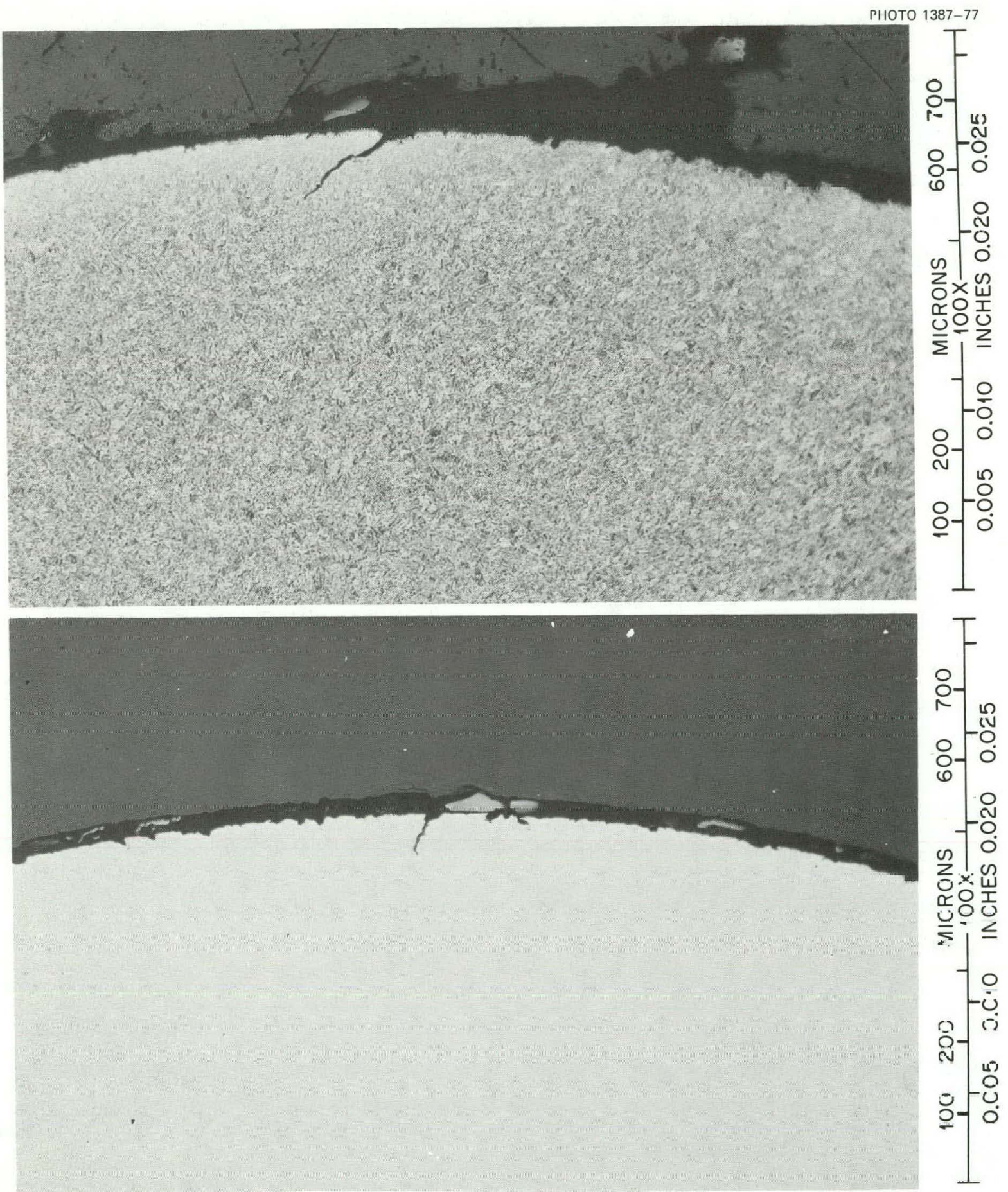

Fig. 7.15. Surface defects in a wire used in the manufacture of tendons $(100 \times)$. These surface defects could serve as sites for the concentration of contaminants that cause stress-corrosion cracking. (Original reduced $42.5 \%)$ 


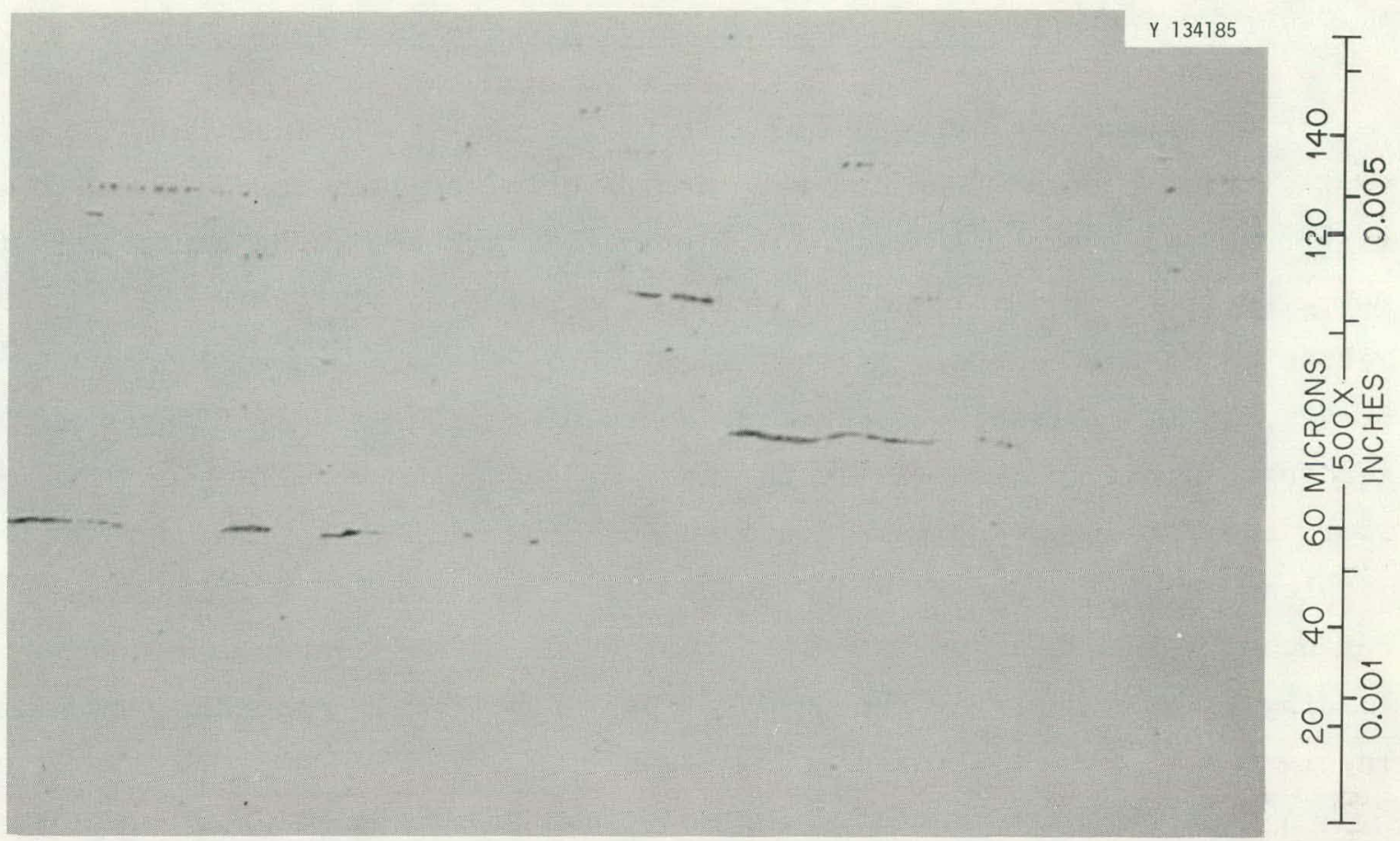

Fig. 7.16. Photomicrograph showing sulfide stringers in the interior of a randomly selected section of circumferential tendons employed in the thermal cylinder test $(500 \times)$. (Original reduced $43 \%$ )

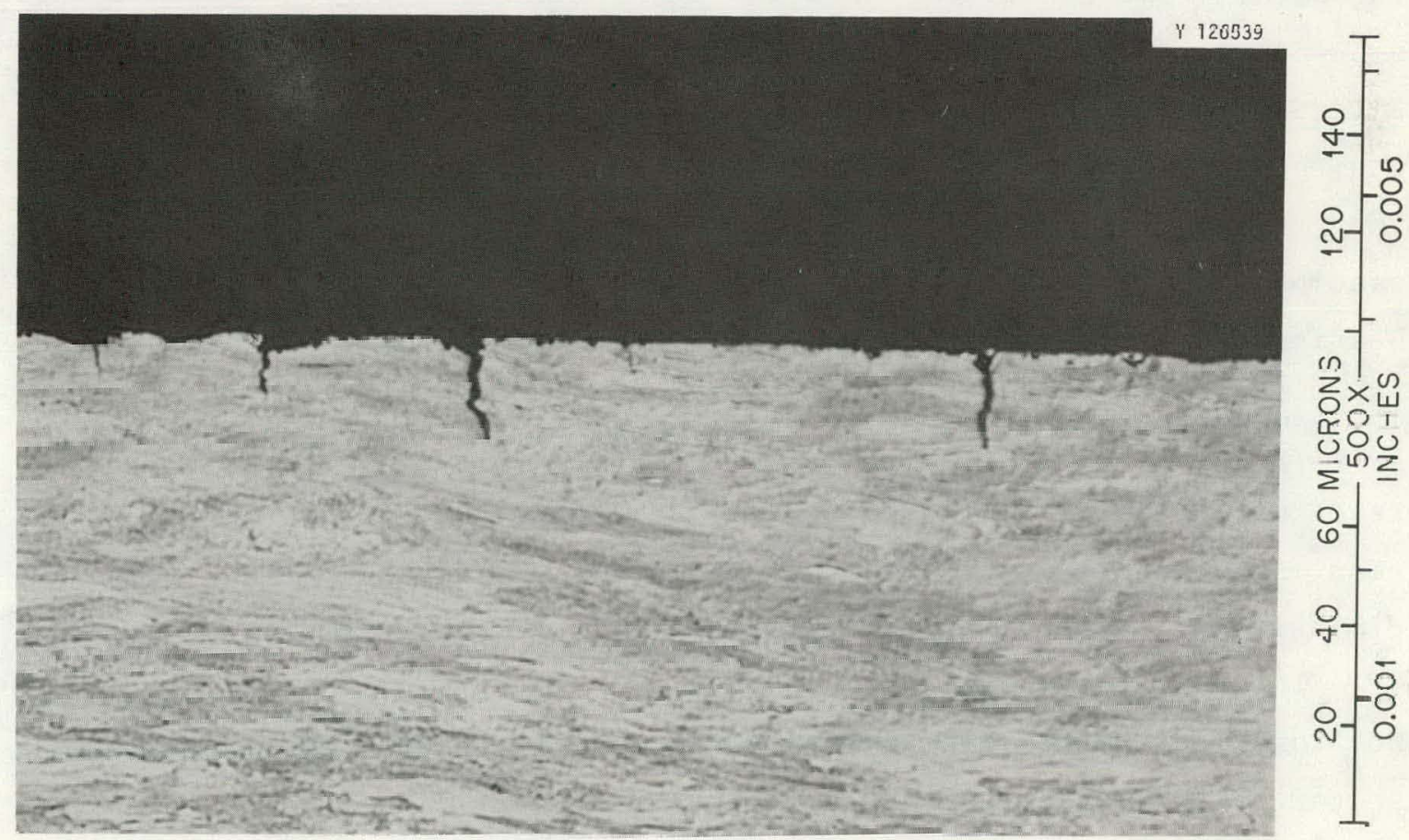

Fig. 7.17. Photomicrograph of a wire that separated during a centerless grinding operation. The cracks, which are perpendicular to the longitudinal axis of the wire, could contribute to premature failure. (Original reduced $43 \%$ ) 


\subsection{Correlation of Analytical Results with Model Test Data}

The differences between the analytical results obtained from the SAFE/ CRACK finite-element code and the results obtained from embedded strain transducers in the ORNL thermal cylinder model seemed to be excessive when compared with similar results found in the published literature. ${ }^{1-13}$ To better judge the accuracy of the experimental results and to identify any trends, it is desirable to compare the results from groups of gages whose readings should be essentially the same. Due to the model design (Fig. 1.3), the effect of end restraints on the strain distribution near the midplane should be negligible. Hence, it is reasonable to ignore differences in the axial position. With the additional assumption that the loading is axisymmetric, the only relevant positional parameter for grouping is the radial position of the gages.

A significant number of gages were located in the neighborhood of three radial positions: (1) $7.6 \mathrm{~cm}$ from the inside wall, (2) at midthickness, and (3) $7.6 \mathrm{~cm}$ from the outside wall. These positions will be referred to as the inside, middle, and outside positions, respectively. The strain-time histories shown in Figs. 7.18 through 7.26 indicate that a number of gages at each location exhibit similar trends throughout the life of the test but have significant differences in strain magnitudes. It was thought that some of these differences could be attributed to the fact that the circumferential prestressing was not uniformly distributed, as assumed in the axisymmetric analysis, but was locally applied through steel bearing pads. These pads were approximately $20.3 \mathrm{~cm}$ wide and had a centerto-center circumferential spacing of $45.7 \mathrm{~cm}$. The effect of this nonuniformity in the loading should be particularly significant for the outer gages but could also be expected to have some effect throughout the thickness, since the thickness of the model wall was of approximately the same dimension as the pad spacing.

In order to investigate the effect of nonuniform loading of the model due to circumferential prestressing, a thin slice from midheight in a sector of the vessel was analyzed, using a radial loading obtained from an analysis of the force transmitted by the prestressing through the bearing pads. Figure 7.27 shows the finite-element mesh, the loading conditions, 


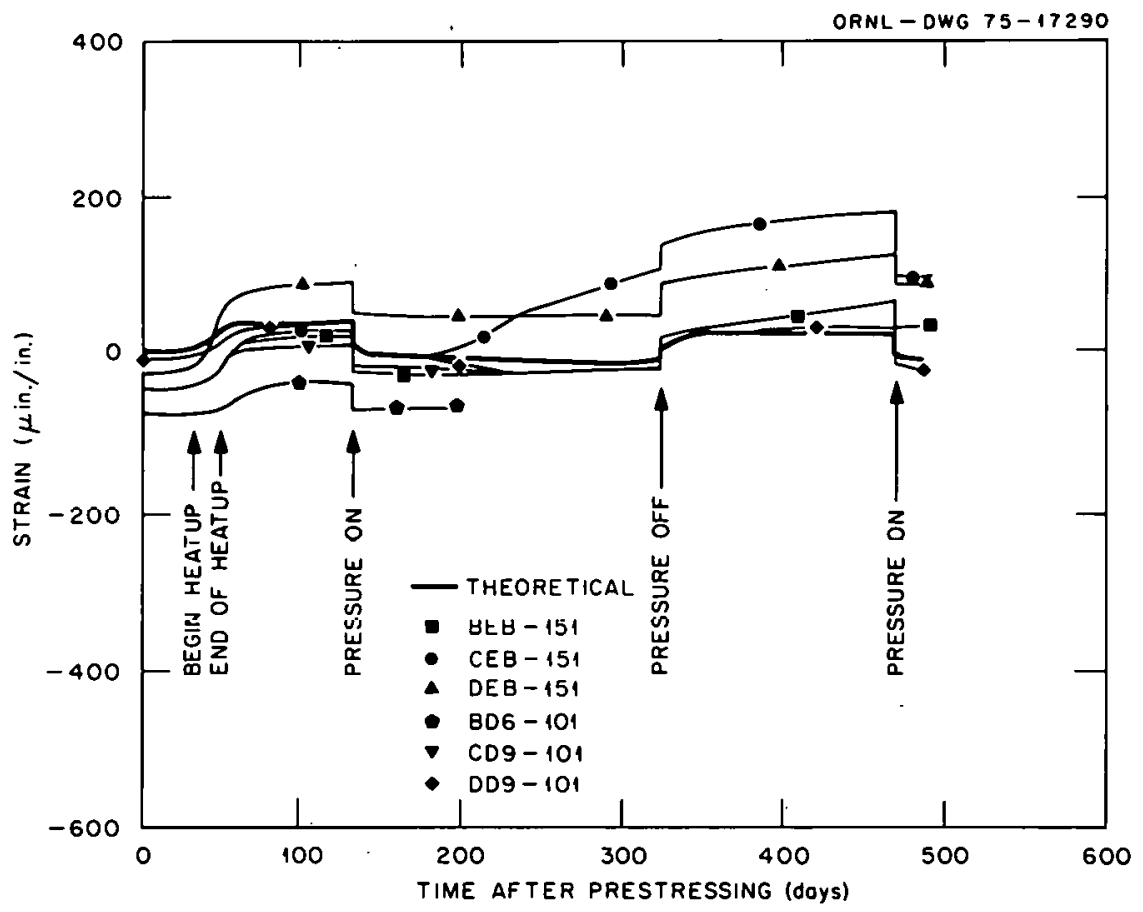

Fig. 7.18. Axial strain $76.2 \mathrm{~mm}$ (3 in.) from inside wall.

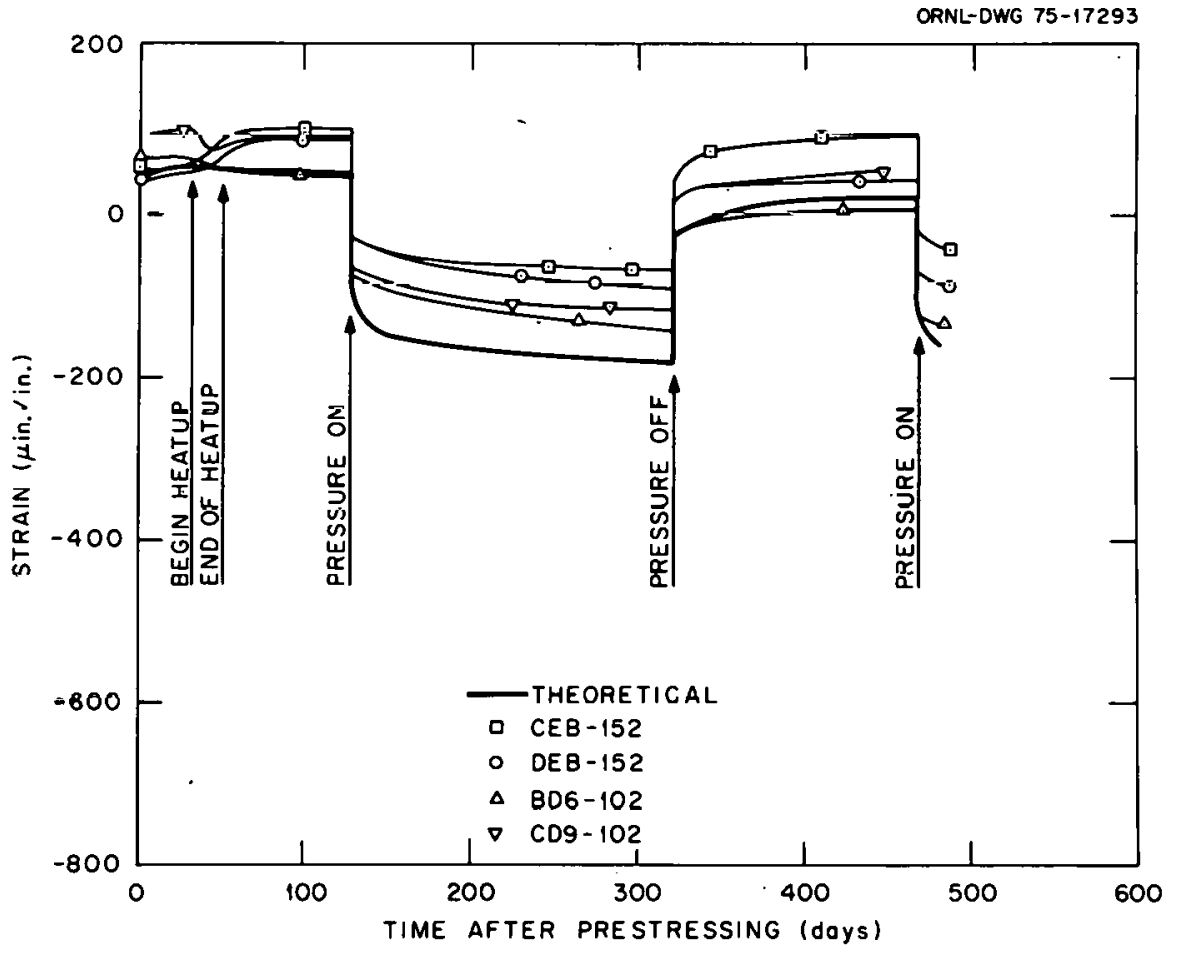

Fig. 7.19. Radial strain $76.2 \mathrm{~mm}$ (3 in.) from inside wall. 


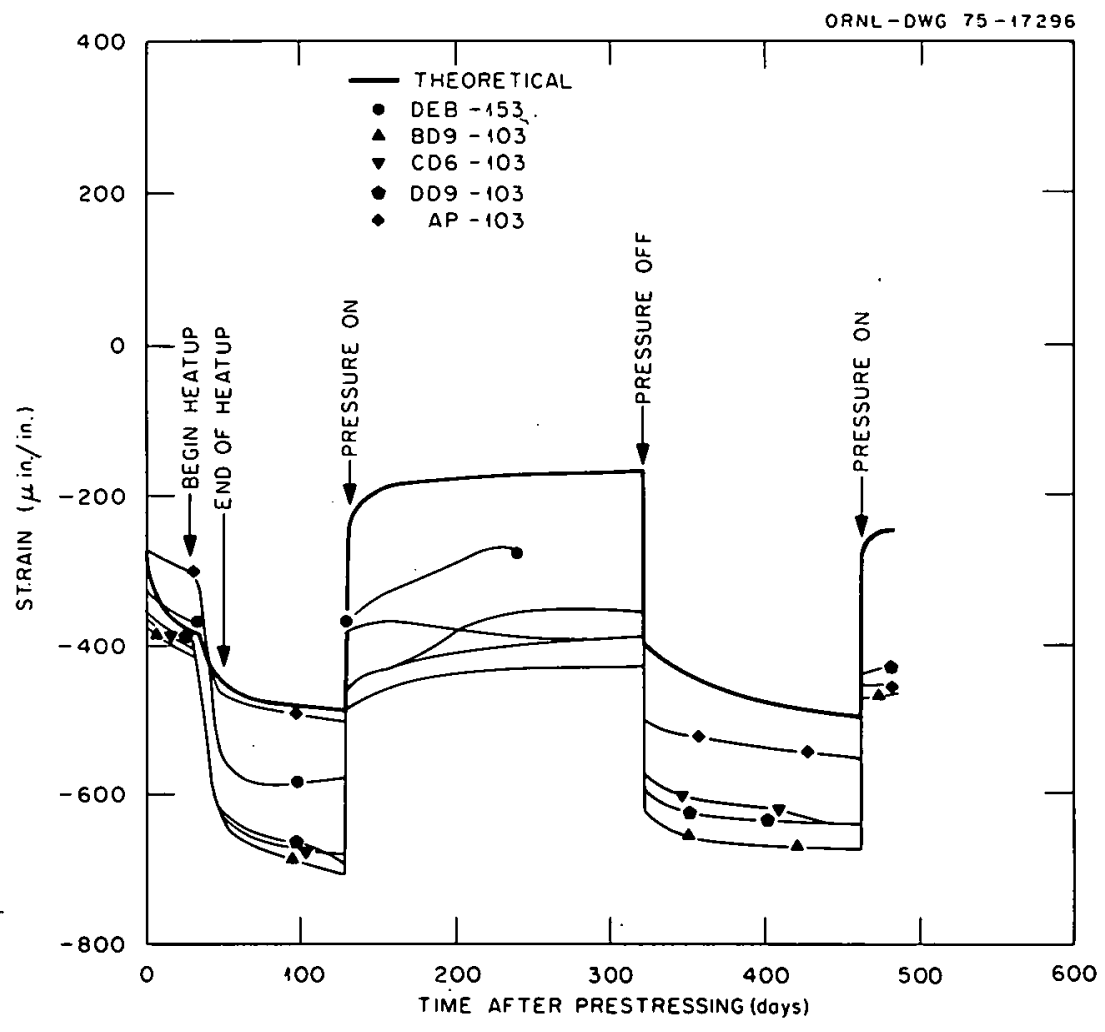

Fig. 7.20. Circumferential strain $76.2 \mathrm{~mm}$ (3 in.) from inside wall.

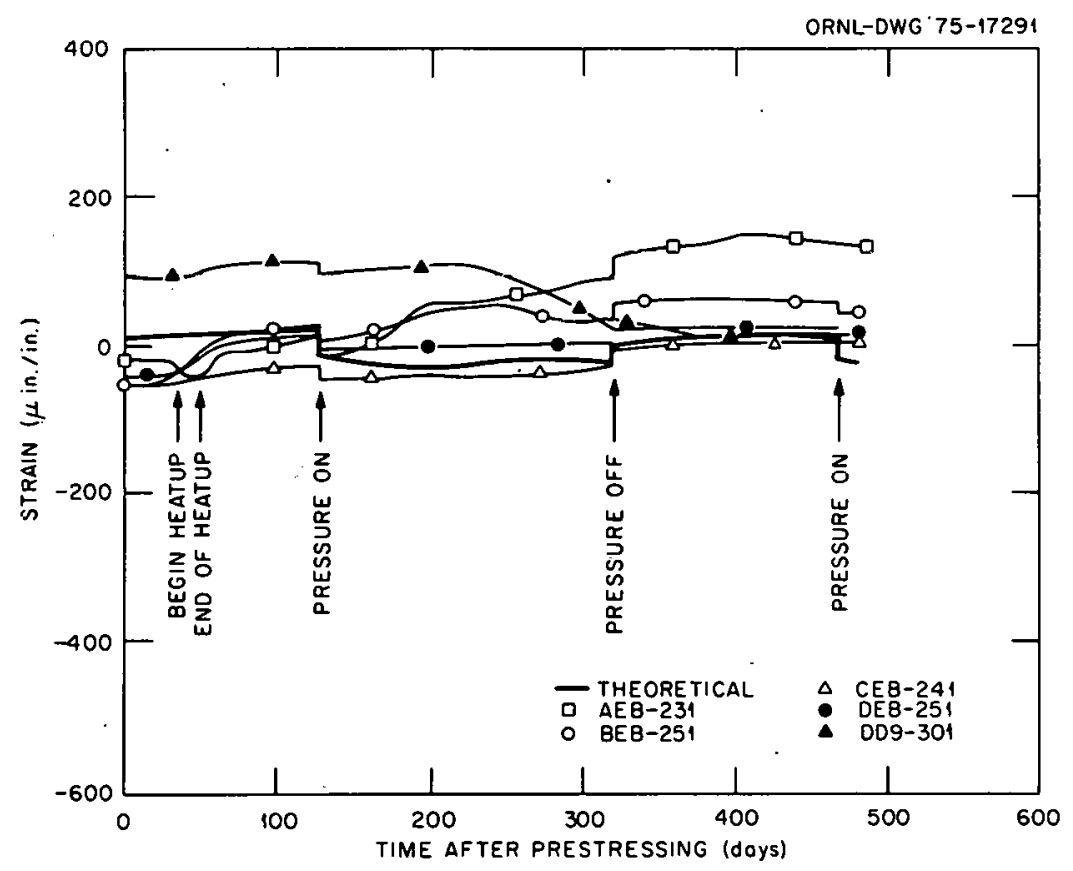

Fig. 7.21. Axial strain at midthickness. 


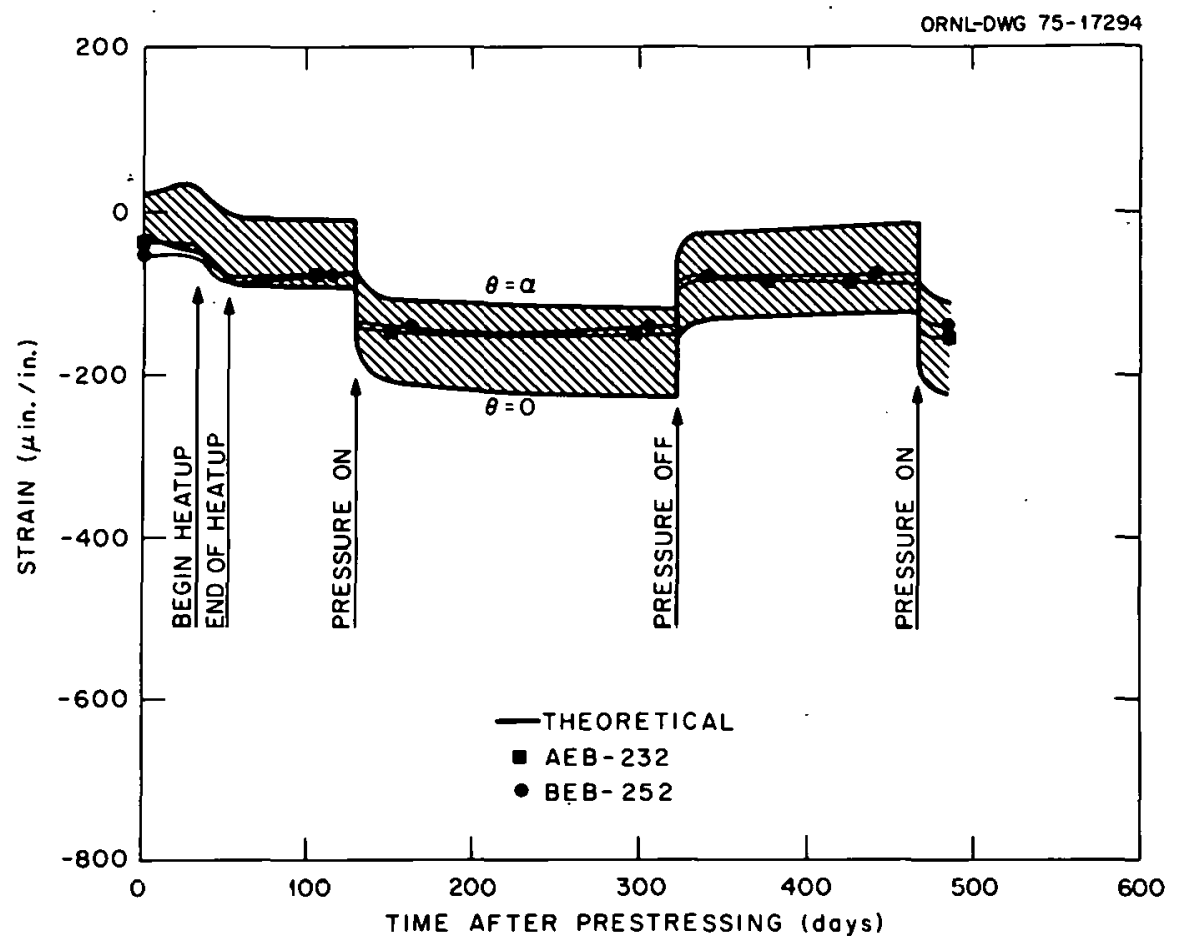

Fig. 7.22. Radial strain at midthickness.

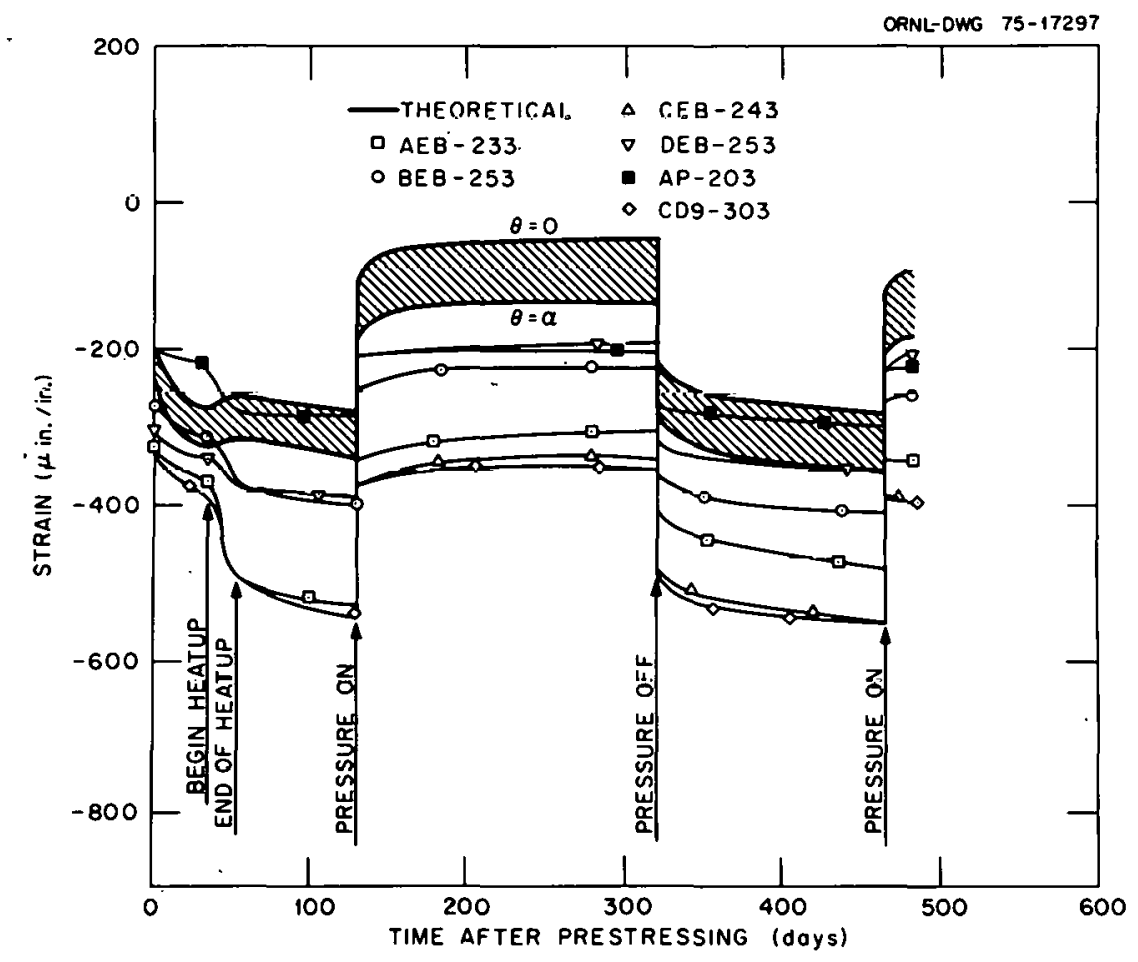

Fig. 7.23. Circumferential strain at midthickness. 


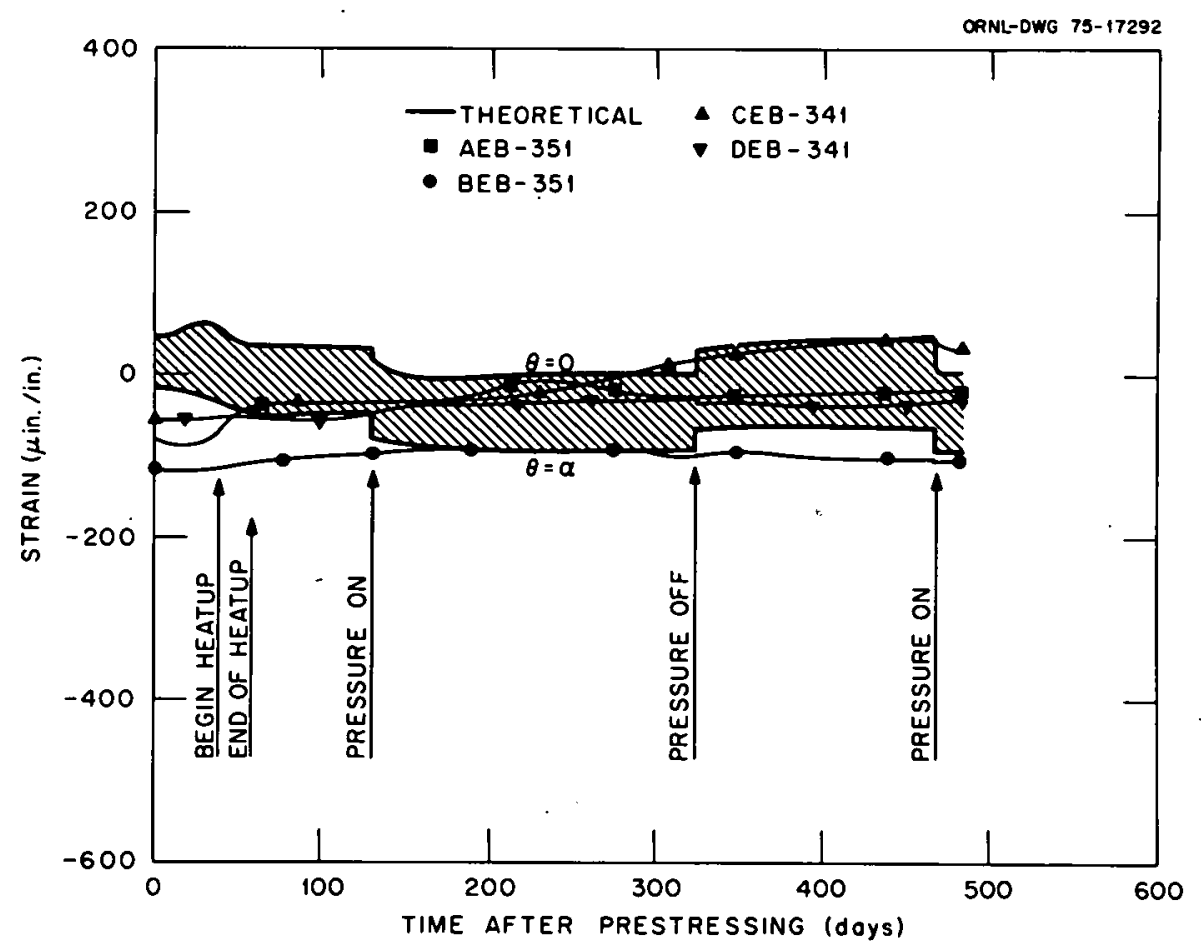

Fig. 7.24. Axial strain $76.2 \mathrm{~mm}$ (3 in.) from outside wall.

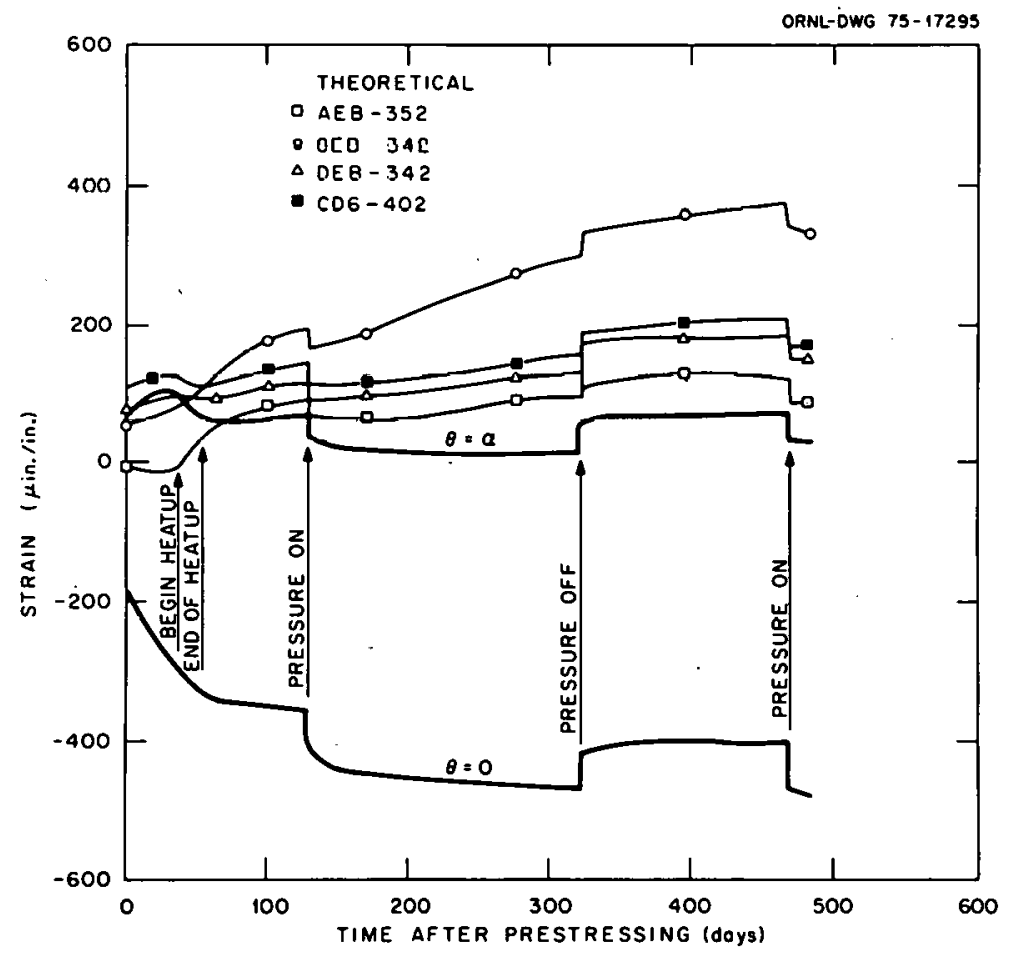

Fig. 7.25. Radial strains $76.2 \mathrm{~mm}$ (3 in.) from outside wall. 


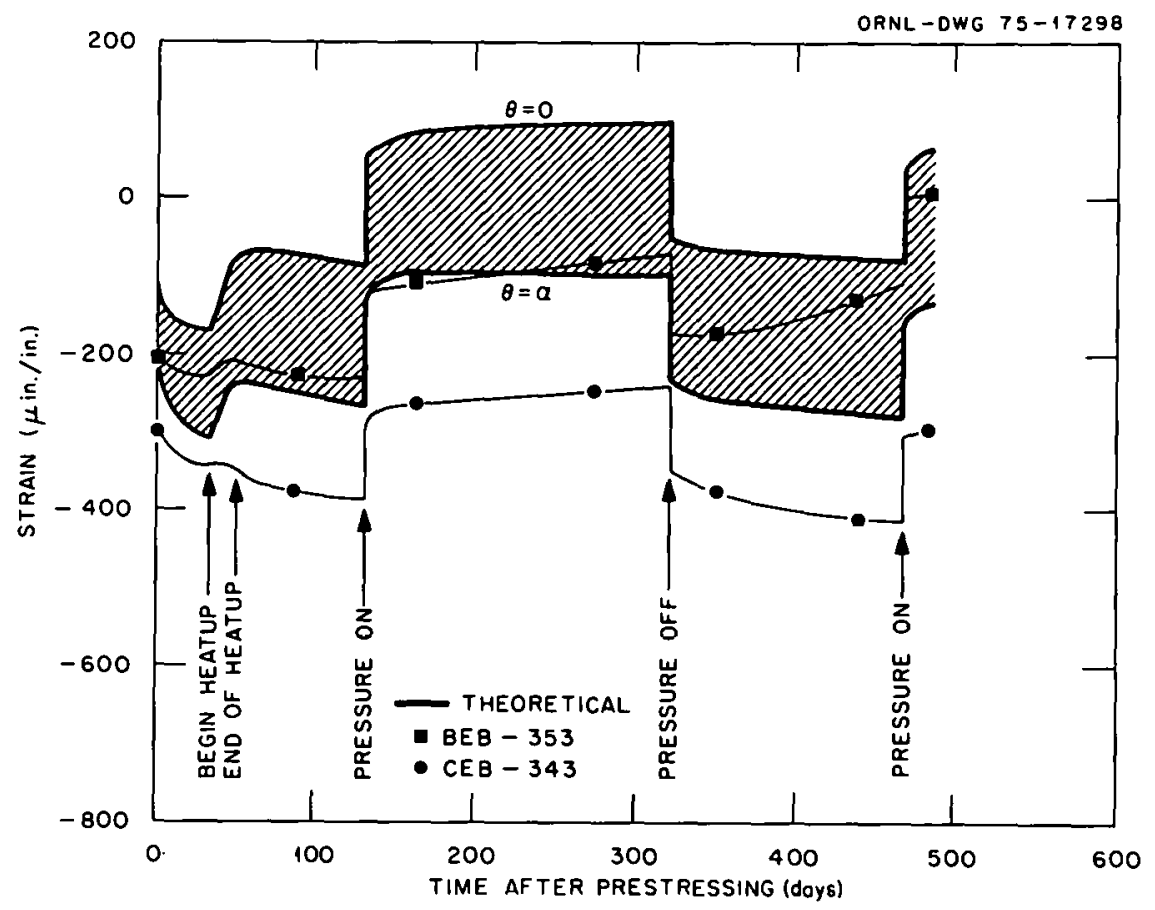

Fig. 7.26. Circumferential strain $76.2 \mathrm{~mm}$ (3 in.) from outside wall.

and the boundary conditions imposed in the analysis. In addition, a constant axial stress was applied to simulate the effect of the axial prestressing. The results from this analysis for radial positions along a ray passing through the center of a pad $(\theta=0)$ and for radial positions midway between adjacent pads $(\theta=\alpha)$ are shown on the Figs. 7.18 through 7.26. The effect of nonuniformity in loading is significant at the outside position (Figs. 7.24 through 7.26) but insignificant at the inside position (Figs. 7.18 through 7.20). Aside from properly accounting for the positive radial strains measured at the outside positions (Fig. 7.25) and better agreement for the axial results (Figs. 7.18, 7.21, and 7.24), the results from the plane and axisymmetric analyses are essentially the same. Thus, the differences in strain readings wi.thin each grouping cannot be explained by the nonuniformity of loading on the outside wall.

The close agreement between the results of the axisymmetric and the plane analyses and the fact that the analytical results lie within the distribution of strain results for most cases (one significant exception being the circumferential strains occurring during vessel heatup) lend a degree of credibility to the accuracy of the analysis. It appears from 
ORNL-DWG $75-17299$

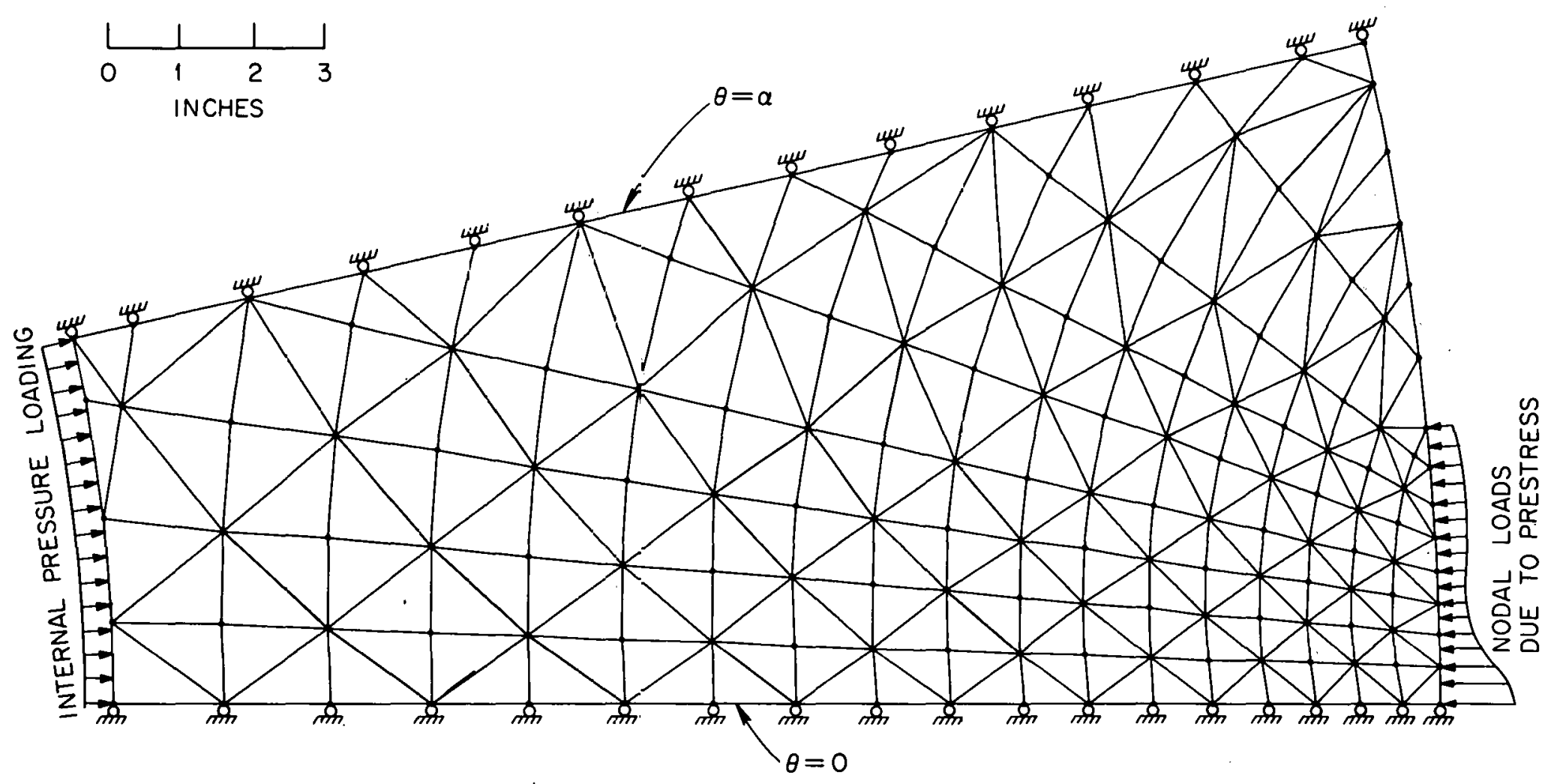

Fig. 7.27. Plane slice at midheight of thermal cylinder ( 1 in. = $25.4 \mathrm{~mm})$. 
the results given in Figs. 7.20 and 7.23 that the algorithm used for calculating creep strains ${ }^{7}$. significantly underestimates the strains occurring during vessel heatup. The creep rate of concrete is known to be approximately proportional to the stress and strongly dependent on the temperature; consequently, the effect of errors in the creep calculations will be most pronounced for the higher stress components at locations having the greatest temperature change, that is, for the circumferential strains at the inside and middle locations (Figs. 7.20 and 7.23). It should be noted that if the observed disagreement between calculated and experimental strains during heatup had been due to an incorrect value for the coefficient of thermal expansion, an equal error would have been produced in the axial and radial strains at these locations, but such an error is not evident (Figs. 7.18, 7.19, and 7.21). The axial and radial stresses at these locations are very low; thus, the corresponding creep strains are small, and even a relatively large percentage error in their calculated values will not be significant. It also should be noted that if the analytical results were corrected for the discrepancy during heatup, close agreement between the analytical and experimental results would be obtained for the remaining portions of the test.

To ensure that the discrepancy during heatup was not the result of incorrect coding of the creep algorithm, the algorithm was independently recoded. There was very little difference in the results from the two independent codings, indicating that the error is fundamental to the algorithm and not the result of improper coding. Since the code reproduced the specified isothermal creep curves and the calculated creep during isothermal conditions seemed to agree with the corresponding experimental results for the thermal cylinder, the probable source of error is in the mathematical generalization of the isothermal creep data to the thermal transient case. A.though the algorithm implemented in the SAFE/CRACK code is widely used, the results of this study and other published results ${ }^{1-13}$ indicate that it underestimates the accumulated creep strain during thermal transient conditions. The effect of this error would probably be less in an actual PCRV than in this test because the heatup is slower, occurs at a later concrete age, and in some cases occurrs after vessel pressurization and hence at lower stress levels. 


\section{CONCLUSIONS AND RECOMMENDATIONS}

\subsection{Conclusions}

The objectives of the thermal cylinder model test were (1) to provide reliable data for evaluating the present capability of predicting the behavior of a PCRV both over its operating history and when subjected to off-design hot-spot heating; (2) to demonstrate structural behavior under design and off-design operating conditions; and (3) to evaluate the performance of instrumentation representative of the types used to monitor PCRVs. These objectives are closely related and cannot necessarily be evaluated separately, since one cannot assume a priori that the gages consistently and accurately monitored existing conditions or that the analysis was entirely correct. We have reached the following conclusions based upon consistent behavior of multiple gages, overall trends seen in analytical and experimental results, and findings of postmortem examinations.

With regard to prestress loadings, good agreement was seen between the applied hydraulic ram loadings and the final loads transferred to the tendons as indicated by the load transducers (Fig. 6.21). Good agreement was also seen between load cell readings and strains measured by the functioning gages attached to individual tendon wires (Fig. 6.20). The axial. loadings remained stable until the onset of sudden corrosion failure of individual wires after about 250 days.

Conventional load cells could not be used with the circumferential tendons owing to their unique design; however, strain gages were attached to individual wires of each strand. During posttensioning, these gages indicated strain reversals caused by the initial straightening of the tendons; however, once they were straightened, subsequent readings showed good agreement with applied hydraulic ram loading steps. Thus, the absolute strain values indicated in Fig. 6.22 do not accurately reflect the total applied loading. However, this figure does show that that tendons did not display any significant relaxation during the various applied sustained loadings.

Although the applied axial loadings were affected by tendon corrosion, these loadings were, by design, relatively small when compared with the 
applied circumferential tendon loadings (161 kN vs $725.5 \mathrm{kN}$ ). Consequently, the observed changes in axial tendon loadings were difficult to detect on the adjacent axial concrete embedment gages.

Comparisons of experimental strain gage data with time-dependent analysis predictions obtained using the SAFE/CRACK finite-element computer program indicated generally good agreement for the normal vessel operating period, although the analysis tended to underestimate heating strains and overestimate mechanical loading strains. The embedded stress cells behaved inconsistently at times; but, generally, they indicated mechanically induced stresses that were lower than the respective calculated values. Significant disagreement was seen between experimental and calculated results for the hot-spot test, thereby indicating the present inability of the analysis to consider abrupt temperature changes.

The postmortem analytical study tended to verify the accuracy of the viscoelastic finite-element algorithm in the SAFE/CRACK code; however, there appears to be a deficiency in the creep algorithm for the thermal transient case; namely, the code predicted cracking where none existed during both the normal operation simulation and the off-design hot-spot heating.

An examination of the sectioned model revealed no cracking, distress, or structural failures that could be attributed to either the simulated operational or hot-spot heating periods. This was true for both the concrete and the steel liner. The only detrimental effect of the hot-spot heating was a significant reduction in the strength of the concrete in a restricted region immediately adjacent to the hot-spot heaters. Readings made using a neutron and gamma-ray backscattering moisture probe showed little if any migration of moisture in the concrete cross section.

The problems encountered with concrete embedment instrumentation were due primarily to a mismatch in gages and readout instrumentation and to insufficient gage evaluation and calibration studies being conducted prior to the experiment. For example, the malfunctioning of the wound-wire resistance gages should have been detected and possibly corrected. Although a large number of the concrete embedment gages provided useful data, it was necessary in many cases to make personal judgments as to whether or not a gage was functioning correctiy. Because of the high cost of installing 
and monitoring gages of these types in an operating PCRV, it is most important that the instrumentation be both dependable and accurate. It is apparent from this experiment that further work is needed to develop highly reliable instrumentation and techniques for installing these gages that preclude damage during construction.

Since concrete behaves in a viscoelastic manner when subjected to sustained loadings and elevated temperature, it is important to have a means for measuring stress directly in the concrete. Such devices remain to be perfected, although this experiment shows they offer some promise.

The problem of tendon corrosion experienced during the thermal cylinder experiment is probably unique because of the particular combination of materials employed. A similar set of conditions should not occur. in a prototype PCRV under normal design conditions. However, epoxy has been used on occasion in the past to repair concrete "honeycombing" in prestressing anchorage regions; and if this practice is employed, it would appear that care should be exercised to ensure that the tendon and tendon duct are fully protected.

\subsection{Recommendations}

The thermal cylinder experiment was designed to bring together the various tasks of the orig1nal ORNL Prestressed Concrete Reactor Vessel - Research and Development Program to culminate in a demonstration of capability to predict the time-dependent behavior of a PCRV during its operating lifetime. The data from this experiment comprise a most important part of the verification of PCRV analysis methods and provide an understanding of the behavior of this type of vessel. Although a great deal of useful information was obtained from the experiment, it was undertaken as a best-effort project based on a restricted time schedule and budget and using instrumentation and calibration provided primarily by the manufacturers. Thus, the following recommendations are based on our experiences in conducting the experiment under the aforementioned constraints.

1. A basic study should be conducted to accurately determine calibration factors and evaluate sealing of all concrete embedment instrumentation. 
2. Existing commerclal stress cells should be evaluated and, if necessary, an Improved stress cell capable of operating at least under potential hot-spot temperatures should be perfected.

3. Present fintte-element methods should be refined so as to include the capability of accurately predicting crack initiation and propagation in regions where complex states of stress exist.

4. Further studies should be made to determine the accuracy of concrete creep algorithms for thermal transient cases and, if necessary, to develop improved algorithms.

5. A program using much simpler structural models should be undertaken to provide a means for evaluating candidate concrete embedment gages in order to determine their capability to accurately monitor structural response and also for evaluating candidate methods of analysis.

6. Finally, once satisfactory instrumentation has been perfected and the previously listed improvements in analysis methods have been developed, a second thermal cylinder model should be tested to provide what should be the final and ultimate verification of PCRV analysis methods. 


\section{REFERENCES}

1. G. D. Whitman, Prestressed Concrete Reactor Vessel Research and Development Progrom Summary, ORNL-TM-2179 (Apr. 1, 1968).

2. J. M. Corum and G. C. Robinson, Jr., "Thermal Cylinder Test to Simulate Behavior of Cylindrical Portion of a Prestressed Concrete Vesse1," GCR Prgram Semiannu. Prog. Rep. Mar. 31, 1969, ORNL-4424, pp. 225-39.

3. J. M. Corum, J. P. Callahan, and M. Richardson, "PCRV Thermal Cylinder Test," Gas-Cooled Reactor and Thorium Utilization Program Semiannu. Prog. Rep. Sept. 30, 1970, ORNL-4637, pp. 70-71.

4. B. Bresler, M. Polivka, and V. Bertero, "Concrete Strength Properties as a Function of Temperature," GCR Program Semiannu. Prog. Rep. Mar. 31, 1969, ORNL-4424, pp. 164-88.

5. Y. R. Rashid, Nonlinear Quasi-Static Analyses of Two-Dimensional Concrete Structures, GA-9994 (Mar. 24, 1970).

6. T. W. Kennedy, An Evaluation and Summary of a Study of the Long-Term Multiaxial Creep Behavior of Concrete, ORNL-TM-5300 (December 1975).

7. Y. R. Rashid, "Nonlinear Analysis of Two-Dimensional Problems in Concrete Creep," Trans. ASME, Ser. E, J. Appl. Mech. 94, 475-82 (1972).

8. R. F. Denkins, GCR Program Semiannu. Prog. Rep. Mar. 31, 1969, ORNL4424, pp. 127-38.

9. A. M. Neville, Properties of Concrete, Wiley, New York, 1963.

10. N. W. Hansen and 0. A. Kurvits, "Instrumentation for Structural Testing," J. PCA Res. Dev. Lab. 7(2), 33 (May 1965).

11. D. Carlton, J. R. Smith, and G. N. Bellwood, "Prestressing and Proof Pressure Testing of the Wylfa Prestressed Concrete Pressure Vessels and Comparison of Measured Data with Predicted Performance," in Proceedings of the First Intemational Conference on Structural Mechanics in Rexctor Technology, Berlin, 1971.

12. F. Bremer, "Practice with Model Techniques," Conference on Model Techniques for Prestressed Concrete Pressure Vessels, The British Nuclear Society, London, 1969.

13. J. R. Smith, "Problems in Assessing the Correlation Between the Observed and Predicted Behavior of Models," Conference on Model Techniques for Prestressed Concrete Pressure Vessels, The British Nuclear Society, London, 1969. 
ORNL/TM-5613

Dist. Category. UC-77

\section{Internal Distribution}

1. S. J. Bal1

2. Seymour Baron

3. D. E. Bartine

4. A. L. Boch

5-16. J. P. Callahan

17. D. A. Canonico

18. J. A. Clinard

19. J. A. Conlin

20. J. H. Coobs

21. W. E. Cooper

22. F. L. Culler

23. J. M. Corum

24. F. C. David

25. J. R. DiStefano

26. W. G. Dodge

27. W. P. Eatherly

28. D. N. Fanning

29. G. G. Fee

30. Uri Gat

31. M. J. Goglia

32. A. G. Grindell

33. W. L. Greenstreet

34. R. C. Gwaltney

35. J. F. Harvey

36. F. J. Homan

37. P. R. Kasten

38. M. Levenson

39. A. L. Lotts
40. R. E. MacPherson

41. A. P. Malinauskas

42. W. R. Martin

43. W. J. McAfee

44. J. G. Merkle

45. R. K. Nanstad

46. D. J. Naus

47. K. J. Notz

48. C. B. Oland

49. H. Postma

50. G. C. Robinson

51. J. P. Sanders

52. M. R. Sheldon

53. G. M. Slaughter

54. G. C. Smith

55. J. E. Smith

56. M. Tobias

57. D. B. Trauger

58. J. R. Weir, Jr.

59. G. D. Whitman

60. R. P. Wichner

61. W. J. Wilcox

62. ORNL Patent Office

63-64. Central Research Library

65. Document Reference Section

66-70. Laboratory Records Department

71. Laboratory Records (RC)

\section{Subcontractors}

72. D. W. Goodpasture, Civil Engineering Department, University of Tennessee, Knoxville, Tenn. 37916

73. W. C. Schnobrich, Civil Engineering Department, University of Illinois, Urbana, Ill. 61801

74. M. A. Sozen, Civil Engineering Department, University of Illinois, Urbana, III. 61801.

75. R. H. Gallagher, Civil Engineering Department, Cornell University, Ithica, N.Y. 14850 
External Distribution

76-77. Director, Division of Nuclear Research and Application, Energy Research and Development Admintstration, Washington, D.C. 20545

78. Director, Reactor Division, ERDA, ORO

79. Research and Technical Support Division, ERDA, ORO

80-256. For distribution as shown in TID-4500 under category UC-77, GasCooled Reactor Technology 